FRANCIELE CORRÊA MACHADO

\title{
CONTRIBUIÇÃO DO SISTEMA CANABINÓIDE E SUA INTERAÇÃ̃ COM O SISTEMA OPIÓIDE NA ANTINOCICEPÇÃO INDUZIDA PELA CROTALFINA, UM ANALGÉSICO TIPO OPIÓIDE
}

Dissertação apresentada ao Programa de Pós-Graduação em Farmacologia do Instituto de Ciências Biomédicas da Universidade de São Paulo, para obtenção do Título de Mestre em Ciências. 


\section{FRANCIELE CORRÊA MACHADO}

Contribuição do sistema canabinóide e sua interação com o sistema opióide na antinocicepção induzida pela crotalfina, um analgésico tipo opióide

Dissertação apresentada ao Programa de Pós-Graduação em Farmacologia do Instituto de Ciências Biomédicas da Universidade de São Paulo, para obtenção do Título de Mestre em Ciências.

Área de concentração: Farmacologia

Orientadora: Profa. Dra. Gisele Picolo

Versão original 


\section{DADOS DE CATALOGAÇÃO NA PUBLICAÇÃO (CIP)}

Serviço de Biblioteca e Informação Biomédica do

Instituto de Ciências Biomédicas da Universidade de São Paulo

reprodução não autorizada pelo autor

Machado, Franciele Corrêa.

Contribuição do sistema canabinóide e sua interação com o sistema opióide na antinocicepção induzida pela crotalfina, um analgésico tipo opióide / Franciele Corrêa Machado. -- São Paulo, 2013.

Orientador: Profa. Dra. Gisele Picolo.

Dissertação (Mestrado) - Universidade de São Paulo. Instituto de Ciências Biomédicas. Departamento de Farmacologia. Área de concentração: Farmacologia. Linha de pesquisa: Dor e analgesia, inflamação, venenos e toxinas animais.

Versão do título para o inglês: Contribution of the cannabinoid system and its interaction with the opioid system in the antinociception induced by crotalphine, an analgesic opioid-like.

1. Dor 2. Analgesia 3. Peptídeos 4. Serpentes 5. Venenos de origem animal 6. Trandução de sinal celular I. Picolo, Profa. Dra. Gisele II. Universidade de São Paulo. Instituto de Ciências Biomédicas. Programa de Pós-Graduação em Farmacologia III. Título. 
Candidato(a):

Título da Dissertação:

Orientador(a):
Franciele Corrêa Machado.

Contribuição do sistema canabinóide e sua interação com o sistema opióide na antinocicepção induzida pela crotalfina, um analgésico tipo opióide.

A Comissão Julgadora dos trabalhos de Defesa da Dissertação de Mestrado, em sessão pública realizada a considerou

( ) Aprovado(a)

( ) Reprovado(a)

Examinador(a): Assinatura:

Nome:

Instituição:

Examinador(a): Assinatura:

Nome:

Instituição:

Presidente: Assinatura:

Nome:

Instituição: 


\section{Certificado}

Certificamos que o protocolo registrado sob $n^{\circ} \mathbf{0 2 9}$ nas fls. 100 do livro 02 para uso de animais em experimentação, sob a responsabilidade do Prof(a) Dr(a)) Yara Cury, Coordenador(a) da Linha de pesquisa * Contribuiçăo do sistema canabinóide e sua interação com o sistema opióide na antinocicepção induzida pela crotalfina, um analgésico tipo opióide" do qual participam o(s) alunos Franciele Corrêa Machado, Vanessa Olzon Zambilli e a pesquisadora Gisele Picolo, está de acordo com os Princípios Éticos de Experimentação Animal adotado pela Sociedade Brasileira de Ciência de Animais de Laboratório (SBCAL) e foi aprovado pela COMISSÃO DE ÉTICA NO USO DE ANIMAIS (CEUA) em 24.03.2011, com validade de 3 anos.

São Paulo, 25 de março de 2011.

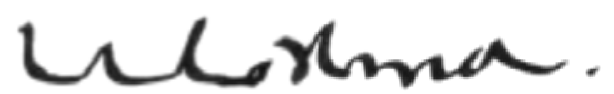

Prof.Dr.WOTHAN TAVARES De LIMA

Coordenador

CEUA - ICB/USP

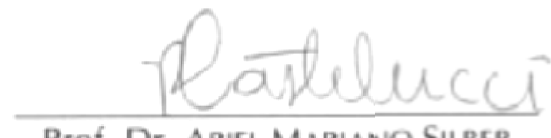

Prof. Dr. ARIEL Mariano SILBER Secretário CEUA - ICB/USP 


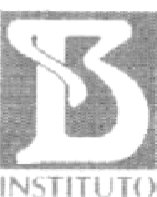
BUTANTAN
COMISSÃO DE ÉTICA NO USO DE ANIMAIS

INSTITUTO BUTANTAN

Av. Dr. Vital Brazil, 1500, CEP 05503-900, São Paulo, SP, Brazil

Telefone: (55) (011) 3726-7222 ramal 2163 - Fax: (55) (011) 3726-1505

\section{CERTIFICADO}

Certificamos que o projeto intitulado "Avaliação da participação de receptores canabinóides no efeito antinociceptivo da crotalfina, um analgésico tipo opióide, e sua interação com o sistema opióide", protocolo $\mathrm{n}^{\text {0 }}$ 622/09, sob a responsabilidade de Gisele Picolo e Franciele Corrêa Machado - que envolve a criação e/ou utilização de animais pertencentes ao filo Chordata, subfilo Vertebrata (exceto o homem), para fins de pesquisa científica - está de acordo com os preceitos da Lei n $^{\circ} 11.794$, de 8 de outubro de 2008, do Decreto 6.899, de 15 de julho de 2009 e de normas complementares, bem como está de acordo com os Princípios Éticos na Experimentação Animal adotado pelo Colégio Brasileiro de Experimentação Animal (COBEA), e foi aprovado pela COMISSĀO DE ÉTICA NO USO DE ANIMAIS DO INSTITUTO BUTANTAN (CEUAIB) em reunião de 08/09/2011.

We certify that the research entitled "Evaluation of the involvement of cannabionoid receptors in the antinociceptive effect of crotalphine", protocol number 622/09, under the responsibility of Gisele Picolo and Franciele Corrêa Machado - which involves the breeding and/or use of animals belonging to phylum Chordata, subphylum Vertebrata (except human beings), for scientific research - is in agreement with Brazilian laws for use of experimental animals and the Ethical Principles in Animal Research adopted by the Brazilian College of Animal Experimentation, and was approved by the ETHICAL COMMITTEE FOR ANIMAL RESEARCH of BUTANTAN INSTITUTE in the meeting of September 08, 2011.

\begin{tabular}{c|c|c|}
\hline Vigência do Projeto: & $\mathbf{N}^{\circ}$ de animais/espécie & ADITIVO \\
$12 / 2009-12 / 2013$ & & 170 ratos Wistar (M) \\
\hline $\begin{array}{c}\text { Laboratório Especial de Dor e } \\
\text { Sinalização }\end{array}$ & 330 ratos Wistar (M) \\
\cline { 2 - 3 }
\end{tabular}

São Paulo, 08 de setembro de 2011.

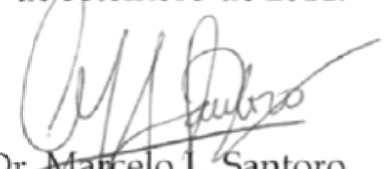

Dr. Aatcelo L. Santoro Coordenador da CEUAIB 
Dedico este trabalho ao grande "Arquiteto" da vida, seja ele quem for, por tê-la feito de uma forma perfeitamente imperfeita, nos permitindo algumas dúvidas e nos impulsionando atrás de respostas.

À mãe natureza, cujos mistérios nós cientistas investigamos incansavelmente com um misto de admiração, surpresa $e$ incredulidade.

Aos meus pais que muitas vezes abdicaram de seus próprios sonhos para que fossem possíveis os meus. Obrigada pela dedicação e esforço em proporcionar à filha sempre o melhor.

Aos familiares, amigos e orientadora pelo incentivo e apoio constante. Obrigada por acreditarem em mim. 


\section{AGRADECIMENTOS}

Àquele a quem a maioria das pessoas se refere como Deus, como eu. Visto a trivialidade que este nome ganhou, muitas vezes se desviando do verdadeiro sentido no qual eu acredito, e respeitando aqui a diversidade religiosa, prefiro chamá-lo nesta presente tese de o grande Arquiteto da vida. Sem a fé, muitas vezes falha, e sem Ele e Nossa Senhora Aparecida este momento não seria possível.

Aos meus pais, papai Francisco e mamãe Simone, pela dedicação incansável. Obrigada pela paciência, ombro amigo, amor incondicional e por sempre me apoiar em minhas decisões, mesmo que elas resultem em dolorida e saudosa distância. Amo vocês.

Aos meus avós. Àqueles que já foram e estão vivos em mim, deixando a lembrança e o exemplo de vida. Afinal, viver no coração daqueles que ficam não é verdadeiramente partir. E àqueles presentes, obrigada pelo apoio e demonstração de que o tempo não é necessariamente um inimigo. Às minhas tias Maristela, Mariléia e Gema por estarem sempre presentes, mesmo à quilômetros de distância. Um agradecimento, em especial, à tia Val: tia de coração, exemplo de mulher guerreira. Única que aturou e compreendeu minha organização ímpar, sempre me paparicando com sorriso no rosto e torcendo pela minha felicidade.

Aos amigos de infância, principais responsáveis por quem eu sou hoje: Lia Carolina, Rachel, Rafaela Lima, Nadja, Thais, Rodrigo Farah, Diego, Matheus, Thiago, Rafael Lopes, Natalia, Rafaela Correia, Priscila, Rodrigo Minotelli, Debora, Bruna e Duda. Em uma brincadeira de criança nos conhecemos e, dessa brincadeira, nasceu uma verdadeira amizade. Amizade que resistiu ao tempo, superou brigas, gerou alegrias, confidencialidades. Aos pais de cada um deles, em especial Nadir, João, Claudia, Douglas, Eliane. Vocês me provaram que para a amizade não há fronteiras, que uma amizade verdadeira como a nossa supera o tempo e a distância.

Aos amigos de faculdade: minha besta friend Paulinha, Lika, Mandí, Chú, Gabi, Carla e o sempre best Lipe. Agradeço principalmente meu sempre amigo e hoje professor Rickinho, pelo incentivo de dar início e continuidade à carreira acadêmica, e a ex-professora Adriana Carneiro por me obrigar a prestar a prova de ingresso no Instituto Butantan e pela indicação do laboratório que "seria a minha cara". Foi difícil encontrá-lo, mas aqui estou.

Meu caloroso agradecimento ao meu novo anjo da guarda, Willian Guapo. Você apareceu no final deste processo, mas já é minha atual motivação e alegria. Obrigada pela paciência e compreensão neste ano de encerramento de ciclos, de início de novos projetos, de novos desafios. 
À Prof ${ }^{a} \operatorname{Dr}^{\mathrm{a}}$ Gisele Picolo, a qual os ensinamentos ultrapassaram os limites da ciência, permitindo-me aprender muito mais do que como ser um bom pesquisador. Ainda tento colocar em prática a difícil (e na maioria das vezes dolorida) reforma íntima, conselho seu durante o primeiro ano de estágio no laboratório: esforço e transformação moral para dominar más inclinações, trocar atitudes erradas por atitudes corretas, erros por acertos que um dia se tornarão virtudes. Trabalhando nisso, também consegui enxergar outras falhas que pretendo combater. Obrigada pelos ensinamentos, puxões de orelha e correções de tese. Meu especial agradecimento por ter dado o privilégio de sua orientação. Com certeza essa convivência me tornou uma profissional muito mais crítica e uma pessoa mais evoluída. Sou grata principalmente pela acessibilidade, por abraçar minhas ideias e por agüentar minhas crises de ansiedade pré-prova, pré-apresentação oral, pré-estágio no exterior. Eu gosto muito de você, te considero um alguém excepcional e de grande valor.

Aos pesquisadores italianos Dr Vincenzo Di Marzo e Dr ${ }^{a}$ Teresa Iuvone, não só por aceitarem colaborar com este projeto, como também pela atenção, dedicação e orientação dispensada. Obrigada pelo aceite e oportunidade de descobrir que há tantas pessoas especiais no mundo, tais como: os canadenses Sabrina, Sofia e Cristóforo; a búlgara Lillyana; a índia Prabha; a japonesa Noriko; a Jihen da Tunísia; o chileno Javier; a Ayacan da Turquia; a espanhola Laura; e os italianos Andrea, Luigi, Marco, Vittoria, Jessica, Roberta, Fabíola, Maria, Giovanna, Irene, Massimo, Luana, Danielle, Barbara, Orsola e Erica. Saudades!

Às amigas Caru e Odília e às tias adotivas Maria Aparecida e Ofênia pelo incentivo e carinho nos primeiros dias desta que foi a maior aventura da minha vida. Nunca vou esquecer vocês e os nossos momentos "Acho chique!". Ao Clube das Luluzinhas pela torcida e devassidões gastronômicas. Agradeço principalmente por cuidarem da minha mãe durante os quatro meses que eu estava fisicamente longe. Obrigada Claudia Arata, Regiane, Miliani, Gabriela, Alessandra, Andrea, Patricia e Claudia Minotelli pela amizade sincera.

À Dr $^{\mathrm{a}}$ Yara Cury e ao Dr. Cristoforo Scavone, pela receptividade e apoio que foram fundamentais no início da minha empreitada científica. Aos demais professores, pesquisadores e alunos do Laboratório de Fisiopatologia do Instituto Butantan e do Departamento de Farmacologia e de Fisiologia Humana do Instituto de Ciências Biomédicas da Universidade de São Paulo, os quais sempre que precisei mostraram-se bastante dispostos. Entre eles, em especial o professor Dr. Emer Suavinho Ferro, Dr. Luíz Roberto G. de Britto e o técnico Adilson pelo apoio metodológico para a preparação das lâminas histológicas e pelo empréstimo de equipamentos do laboratório. 
À $\operatorname{Dr}^{\mathrm{a}}$ Andrea e à técnica Miriam pela colaboração, disponibilidade, amizade, auxílio na redação do artigo, sugestões e críticas sempre bastante pertinentes e que certamente contribuíram (e continuam contribuindo) de forma perspicaz para o desenvolvimento deste estudo. Obrigada também para as demais colaboradoras oficiais deste projeto, Vanessa Zambelli e Ana Carolina, pelos ensinamentos e apoio nos momentos em que o prazo foi curto.

Ao Prof. Dr. Benedito Carlos Prezoto do Departamento de Farmacologia do Intituto Butantan pela atenção e disponibilidade, bem como pelo fornecimento de captopril, ferramenta farmacológica utilizada no ensaio in vivo. Aos professores Dr $^{\mathrm{a}}$ Carolina Munhoz, $\operatorname{Dr}^{\mathrm{a}}$ Andrea Torrão, Dr Jair Guilherme e Dr Carlos A. Parada, por terem aceitado avaliar este trabalho, no momento da qualificação e/ou na defesa da tese. Certamente, vossos conhecimentos irão engrandecer este trabalho.

Aos funcionários da linha 11 de fretamento de ônibus da Associação dos Executivos da Baixada Santista (AEBS), pela árdua missão de ir e vir todos os dias da Baixada Santista à São Paulo. Obrigada Ailton e Seu Lima pelo transporte de qualidade e segurança.

Aos funcionários do biotério central do Instituto Butantan e, de forma especial, do biotério do Laboratório Especial de Dor e Sinalização (LEDS): Claudemir, Tania e Sandra, sempre prestativos e sem medir esforços para me atender nos momentos que precisei. Obrigada pela amizade, abraços, torcida, carinho e por garantirem o bem-estar dos meus animais de experimentação. Aos amigos do Intituto Butantan e da Universidade de São Paulo: Grecco, Paola, Paula, Elis, amigo e professor de italiano Julian, Luana, Felipe, Louise e meu sempre pós-doc favorito Emerson. Sempre bom estar e conviver com vocês. Muito obrigada!

Às amigas mais que especiais: Marina Toddynho, minha eterna companheira de aventuras; Marianne, o coração mais valioso dentro de uma amiga Má e; Evelyn, a hiperatividade em pessoa. Aos amigos de todos os dias, da bancada para a vida: Nathália, Caru, Leandro Márcio, Luciana e Lais. É de pessoas assim como vocês que o mundo está precisando. Seres especiais e iluminados que trazem uma marca registrada de dignidade, fidelidade, companheirismo e solidariedade. Obrigada a todos vocês pela amizade desinteressada e sincera, pelo companheirismo em congressos, viagens, almoços (principalmente no Outback, Mc Donalds e Subway) e pelos momentos de descontração (em particular, a procrastinação na copinha). Esses momentos foram imprescindíveis para uma boa convivência e, conseqüentemente, para que o trabalho pudesse fluir da melhor maneira possível. Amo vocês. E não é pouco. É pra sempre. Ao infinito e além.

À FAPESP e INCTTOX pelo apoio financeiro, fundamental para que eu pudesse desenvolver este trabalho. 
Há pessoas estrelas e há pessoas cometas. Os cometas passam. (...) As estrelas permanecem. (...) Há muita gente cometa. Passa pela vida da gente apenas por instantes. (...) gente que passa pela vida sem iluminar, sem aquecer, sem marcar presença. Importante é ser estrela. Estar junto. Ser luz. Ser calor. Ser vida.Ser cometa é ser companheiro por instantes, explorar os sentimentos humanos, ser aproveitador das pessoas e das situações, fazer-se acreditar e desacreditar ao mesmo tempo. (...) Há necessidades de criar um mundo de estrelas. Todos os dias poder contar com elas e poder sentir seu calor. Assim são os amigos estrelas na vida da gente. São coragem nos momentos de tensão. São luz nos momentos de desânimo. Ser estrela neste mundo passageiro, nesse mundo cheio de pessoas cometas, é desafio, mas acima de tudo uma recompensa. Recompensa de ter sido luz para muitos amigos, ter sido calor para muitos corações.

Reinilson Câmara

Trecho de As Estrelas e os Cometas

- Quanta asneira! - disse Alice bem alto. Onde já se viu dar a sentença antes de julgar se o acusado é culpado ou não?

- Mais cuidado com o que fala! - gritou a Rainha, ficando toda vermelha de raiva.

- Vou falar o que eu quiser! - respondeu Alice.

- Cortem a cabeça dela! Cortem a cabeça dela! - pôs-se a berrar a Rainha, com toda a força dos seus pulmões.

Mas ninguém se mexeu.

- Quem é que liga para você? - disse Alice (ela já tinha voltado ao seu tamanho normal nesse momento). - Vocês não passam de um pacote de cartas de baralho.

Lewis Carroll

Trecho de Alice no País das Maravilhas 


\section{RESUMO}

MACHADO, F. C. Contribuição do sistema canabinóide e sua interação com o sistema opióide na antinocicepção induzida pela crotalfina, um analgésico tipo opióide. 2013. 87 f. Dissertação (Mestrado em Farmacologia) - Instituto de Ciências Biomédicas, Universidade de São Paulo, São Paulo, 2013.

Substâncias derivadas de venenos animais que interferem com processos nociceptivos tem sido investigadas há anos. Dentre estas substâncias, a crotalfina, é um peptídeo de 14 aminoácidos, análogo sintético do primeiro peptídeo analgésico identificado e isolado de cascavéis sul-americanas Crotalus durissus terrificus. Esse peptídeo induz potente e duradouro (2-5 dias) efeito analgésico, quando avaliado em modelos experimentais de dor. Esse efeito é mediado pela ativação de receptores opióide periféricos do tipo kappa (dor aguda) ou kappa e delta (dor crônica). Apesar da atividade opióide, estudos sobre mecanimos moleculares indicam que esse peptídeo não se liga diretamente aos receptores opióides, sugerindo que a liberação de opióides endógenos sejam os responsáveis pela atividade analgésica. Baseado em dados da literatura que demonstram a liberação de opióides endógenos induzida por receptores canabinóides ou de endocanabinóides por receptores opióides, o objetivo deste trabalho é caracterizar os mecanismos envolvidos no efeito antinociceptivo da crotalfina. Em todos os experimentos, a hiperalgesia aguda foi induzida por prostaglandina $\mathrm{E}_{2}$. Utilizando o teste de pressão de pata, um modelo in vivo de avaliação da sensibilidade dolorosa, nossos dados demonstram que ambos antagonistas para receptores $\mathrm{CB}_{1}$ e $\mathrm{CB}_{2}$ e anticorpo anti-dinorfina $\mathrm{A}$ inibiram o efeito antinociceptivo da crotalfina. Resultados obtidos por técnica de imunofluorescência também confirmam que a crotalfina aumentou a ativação de receptores $\mathrm{CB}_{2}$ e kappa no tecido plantar de ratos. Ensaios imunoenzimáticos mostraram que a crotalfina induz liberação local de dinorfina A e que esta liberação é bloqueada por antagonista $\mathrm{CB}_{2}$. Administração local de um inibidor irreversível da enzima de degradação de endocanabinóides aumentou a antinocicepção periférica produzida por baixa dose de crotalfina. Ainda, a ligação da crotalfina em receptores $\mathrm{CB}_{2}$ foi confirmada em ensaio de ligação competitiva. Em suma, os resultados indicam que receptores $\mathrm{CB}_{2}$ estão envolvidos na antinocicepção induzida pela crotalfina. Esse efeito é dependente de liberação de opióides endógenos, particularmente dinorfina A, sendo essa liberação dependente de ativação direta do receptor $\mathrm{CB}_{2}$.

Palavras-chave: Antinocicepção. Analgesia. Crotalfina. Canabinóide. Opióide. 


\begin{abstract}
MACHADO, F. C. Contribution of the cannabinoid system and its interaction with the opioid system in the antinociception induced by crotalphine, an analgesic opioid-like. 2013. 87 p. Masters thesis (Pharmacology) - Instituto de Ciências Biomédicas, Universidade de São Paulo, São Paulo, 2013.

Substances derived from animal venoms that interfere with the nociceptive processes have been investigated for years. One of these substances is crotalphine, a 14 amino acid peptide that is a structural analogue of a novel analgesic peptide first identified and isolated from the venom of the South American rattlesnake Crotalus durissus terrificus. This peptide induces a potent and long lasting (2-5 days) analgesic effect, when evaluated in experimental models of pain. This effect is mediated by activation of peripheral kappa (acute pain) or kappa and delta (chronic pain) opioid receptors. Despite the opioid-like activity, studies about the molecular mechanisms indicate that this peptide does not directly bind to opioid receptors, suggesting that the release of endogenous opioids may be responsible for its analgesic activity. Based on data from literature demonstrating the release of opioid peptides by cannabinoids or endocannabinoids by opioids, the aim of this work is to characterize the mechanisms involved in the antinociceptive effect of crotalphine. In all experiments, acute hyperalgesia was induced by prostaglandin $\mathrm{E}_{2}$. Using the paw pressure test, an in vivo model of pain evaluation, it was demonstrated that both $\mathrm{CB}_{1}$ and $\mathrm{CB}_{2}$ receptor antagonists and antibody anti-dynorphin A inhibited the antinociceptive effect of crotalphine. Results obtained by immunofluorescence technique also confirm that crotalphine increased the activation of $\mathrm{CB}_{2}$ and kappa receptors in the skin tissue from rat paw. Enzyme immunoassay showed that crotalphine induces the local release of dynorphin- $\mathrm{A}$ and this release is blocked by $\mathrm{CB}_{2}$ receptor antagonist. Local administration of irreversible inhibitor of endocannabinoid degradation enhanced the peripheral antinociception produced by low dose of crotalphine. In addition, binding of crotalphine to $\mathrm{CB}_{2}$ receptors was confirmed in a competitive binding assay. These results indicate that $\mathrm{CB}_{2}$ receptors are involved in antinociception induced by crotalphine. This effect is dependent of endogenous opioids release, particularly dynorphin- $\mathrm{A}$, been this release dependent of directly $\mathrm{CB}_{2}$ receptor activation.
\end{abstract}

Keywords: Antinociception. Analgesia. Crotalphine. Cannabinoid. Opioid. 


\section{LISTA DE FIGURAS}

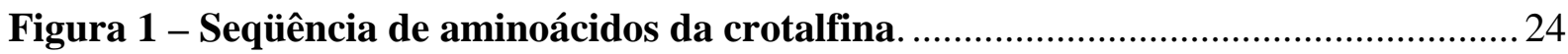

Figura 2 - Extração do veneno bruto de serpentes Crotalus durissus terrificus. .............. 25

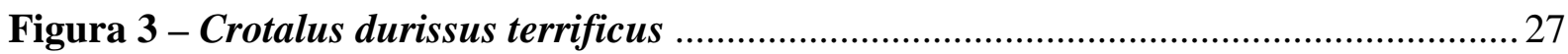

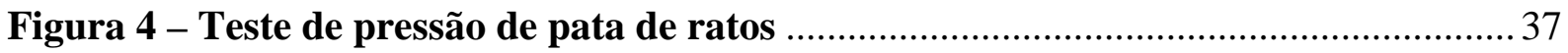

Figura 5 - Curva tempo-resposta do efeito nociceptivo da PGE 2 .................................. 43

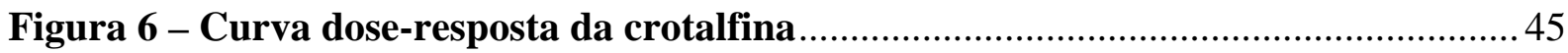

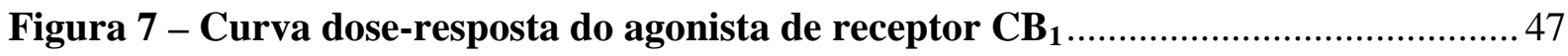

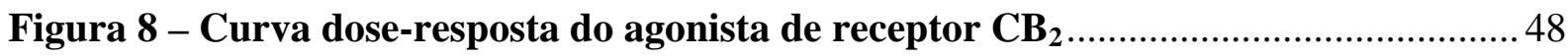

Figura 9 - AM251 foi capaz de reverter o efeito local induzido pelo ACEA .................. 49

Figura 10 - AM630 foi capaz de inibir o efeito local do AM1241 .................................. 50

Figura 11 - Atividade antinociceptiva da crotalfina é mediada por receptores

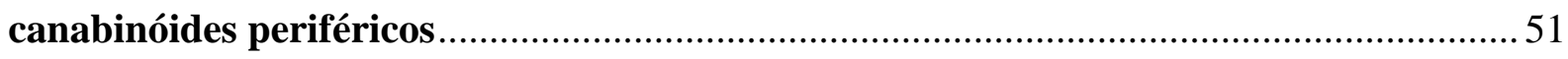

Figura 12 - Tratamento local com crotalfina induz aumento no nível de ativação de

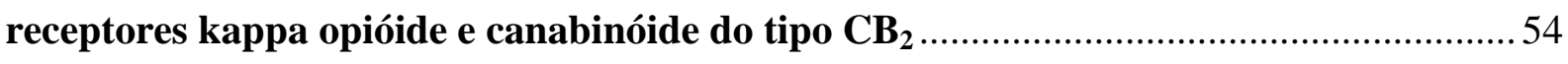

Figura 13 - Inibição do precursor dos endocanabinóides não interfere com o efeito da

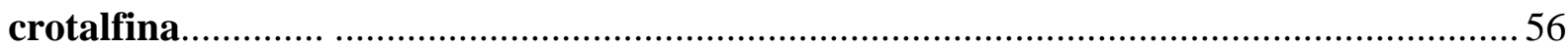

Figura 14 - A inibição de enzima metabolizadora de endocanabinóides potencializa o

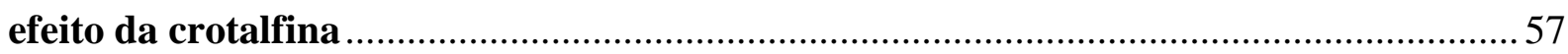

Figura 15 - Atividade antinociceptiva da crotalfina na vigência de hiperalgesia induzida

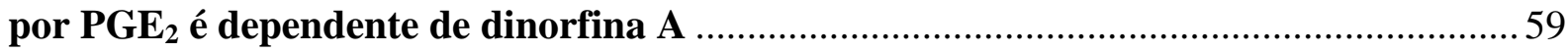

Figura 16 - A inibição de enzima metabolizadora de dinorfina A potencializa o efeito antinociceptivo da crotalfina 61

Figura 17 - A liberação de dinorfina A do tecido plantar de ratos pré-tratados com $\mathrm{PGE}_{2}$ induzida pela crotalfina é dependente de receptores canabinóides locais do tipo $\mathrm{CB}_{2}$

Figura 18 - Curva sigmoidal concentração-resposta do ensaio de binding competitivo da crotalfina sobre receptores tipo $\mathbf{C B}_{2}$ 


\section{LISTA DE TABELAS}

Tabela 1 - Ordem de incubação para realização do ensaio de ligação específica para

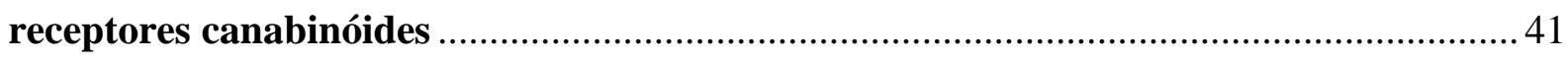

Tabela 2 - Ensaio de binding competitivo da crotalfina sobre receptores tipo CB $_{1} \ldots \ldots . .64$

Tabela 3 - Dados farmacológicos do ensaio de binding competitivo da crotalfina sobre

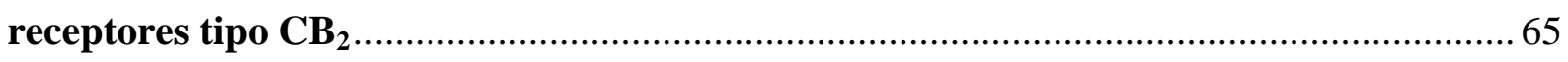




\section{LISTA DE ABREVIATURAS E SIGLAS}

$\Delta$ '-THC: delta $^{9}{ }^{9}$-tetrahidrocanabinol

2-AG: 2-aracdonil-glicerol ; endocanabinóide

ACEA: arachidonyl-2-chloroethylamide; agonista de receptores canabinóides tipo 1

AEA: aracdonil-etanolamida; andamida; endocanabinóide

AM1241: (2-iodo-5-nitrophenyl) - (1-(1-methylpiperidin-2-ylmethyl) - $1 \mathrm{H}$ - indol-3 -yl) methanone; agonista de receptores canabinóides do tipo 2

AM251: N-(Piperidin-1-yl) - 5 - (4-iodophenyl) - 1 - (2,4-dichlorophenyl) - 4-methyl - $1 \mathrm{H}$ pyrazole - 3 - carboxamide; antagonista de receptores canabinóides tipo 1

AM630: 6 - Iodo - 2-methyl - 1-[2-(4-morpholinyl)ethyl] - 1H-indol-3-yl] (4-methoxyphenyl) methanone; antagonista de receptors canabinóides tipo 2

Bmax: capacidade de ligação máxima; número máximo de sítios de ligação de um receptor

BSA: Soro fetal bovino; conhecido também como "Fração V"

$\mathbf{C a C l}_{2}$ : cloreto de cálcio

$\mathbf{C B}_{1}$ : receptores canabinóide do tipo 1

$\mathbf{C B}_{2}$ : receptores canabinóides do tipo 2

CEUAIB: Comissão de Ética para Uso de Animais do Instituto Butantan

cm: centímetro

DMSO: Dimetilsulfóxido

ELISA: Enzyme-linked immunosorbent assay; Ensaio Imunoadsorvente Ligado à Enzima

FAAH: enzima ácido graxo amida hidroxilase

g/s: gramas por segundo

g: gramas

GPCR: $G$ protein coupled receptors; receptores acoplados à proteína $\mathrm{G}$

HBSS: Hank's Buffered Salt Solution; Solução Balanceada de Hank`s

IC $_{\mathbf{5 0}}$ : concentração do agente competidor na qual se obtém $50 \%$ de inibição da ligação do radioligante

i.pl.: via intraplantar

KCl: cloreto de potássio

$\mathbf{K} \boldsymbol{d}$ : constante de dissociação do ligante radiomarcado (obtido por ensaio de saturação "Scatchard")

Ki: constante de dissociação do agente competidor não radiomarcado (mesma definição de $\mathrm{K} d$, só que obtido através de ensaio de competição, e não de saturação) 
$\mathbf{K H}_{2} \mathrm{PO}_{4}$ : Diidrogenofosfato de potássio, fosfato monobásico de potássio ou Fosfato monopotássico

log: logaritmo na base 10

M: concentração molar

MAFP: (5Z,8Z,11Z,14Z)-5,8,11,14 - eicosatetraenyl - methyl ester phosphonofluoridic acid; inibidor da enzima ácido graxo amida hidroxilase, responsável por degradar os endocanabinóides

MF: medida final, pós-tratamento

$\mathbf{M g C l}_{2}$ : cloreto de magnésio

MAGL: enzima lipase monoacilglicerol

MgSO 4 : sulfato de magnésio

MI: medida inicial, basal

mg: mili grama $\left(10^{-3}\right.$ grama)

mM: mili molar $\left(10^{-3}\right.$ molar $)$

$\mu \mathrm{g}$ : micro grama $\left(10^{-6}\right.$ grama)

$\boldsymbol{\mu M}$ : micro molar $\left(10^{-6}\right.$ molar $)$

$\mathrm{Na}_{2} \mathrm{HPO}_{4}$ : Fosfato monossódico (fosfato de sódio monobásico)

NaCl: cloreto de sódio

$\mathrm{NaHCO}_{3}$ : bicarbonato de sódio

ng: nano grama $\left(10^{-9}\right.$ grama)

nM: nano molar $\left(10^{-9}\right.$ molar $)$

NorBNI: nor-binaltorfimina; antagonista de receptores kappa opióide

Orlistat: N-Formyl-L-leucine(1S)-1-[[(2S,3S)-3-hexyl-4-oxo-2-oxetanyl]methyl]dodecyl

Ester; um inibidor do diacilglicerol, precursor dos endocanabinóides, produzido a partir da hidrólise de fosfoinositídeos de membrana

p.o.: per os (do latim, pela boca); via oral

PGE $_{2}$ : prostaglandina $\mathrm{E}_{2}$

pH: potencial de hidrogénio iônico

s.c.: via subcutânea

SNC: Sistema Nervoso Central

TNF: Fator de Necrose Tumoral

TRPV1: receptor de potencial transiente vanilóide 1

VCdt: veneno da serpente Crotalus durissus terrificus 


\section{SUMÁRIO}

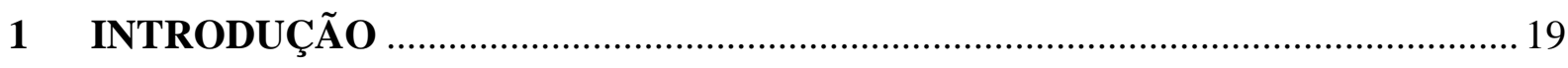

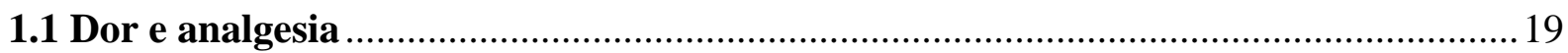

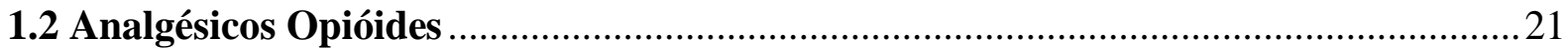

1.3 Estudos sobre a crotalfina e sua interação com o sistema opióide ............................24

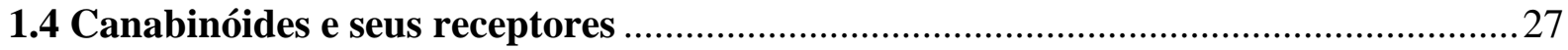

1.5 Propriedades analgésicas dos canabinóides e sua interação com opióides ................. 31

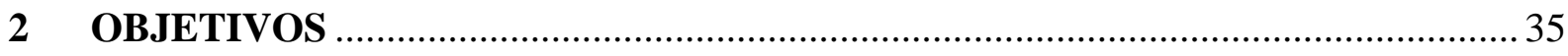

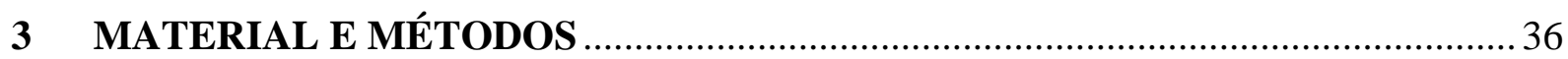

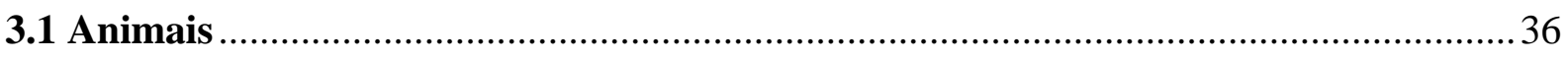

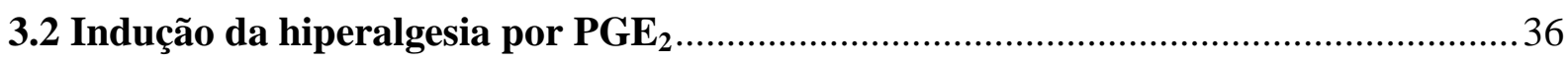

3.3 Avaliação da sensibilidade dolorosa: Determinação da hiperalgesia ..........................36

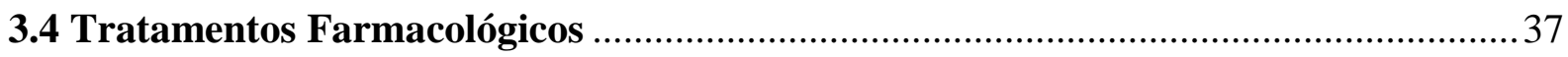

3.5 Determinação da atividade de receptores canabinóides e opióides: Imunomarcação

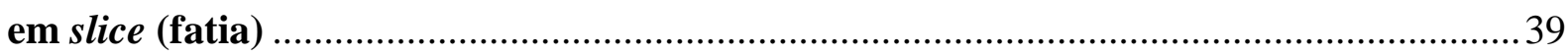

3.6 Avaliação da possível liberação local de opióides endógenos, por células do tecido

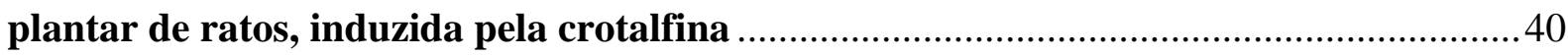

3.7 Ensaio de ligação específica para receptores canabinóides ...................................... 40

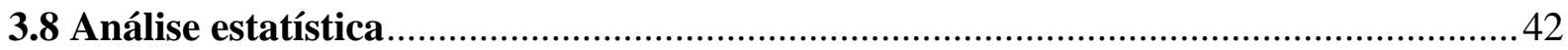

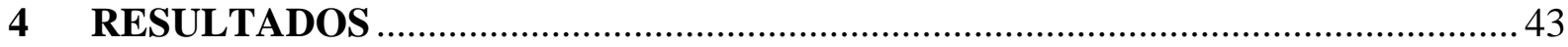

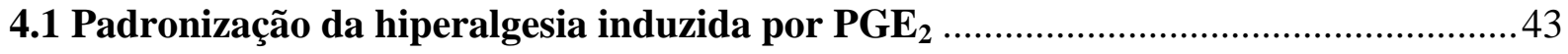

4.2 Efeito sistêmico e local da crotalfina sobre a hiperalgesia induzida por PGE $_{2} \ldots \ldots \ldots . . .44$

4.3 Avaliação da atividade de agonistas e antagonistas canabinóides $\mathbf{C B}_{\mathbf{1}} \mathbf{e} \mathbf{C B}_{2} \ldots \ldots \ldots \ldots . . . .46$

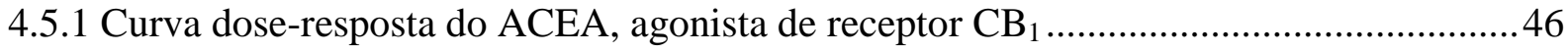

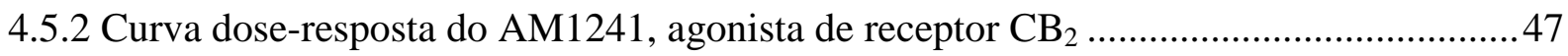

4.5.3 Avaliação do AM251 sobre o efeito antinociceptivo do ACEA ...................................48

4.5.4 Avaliação do AM630 sobre o efeito antinociceptivo do AM1241 ................................49 
4.6 Avaliação da participação do sistema canabinóide no efeito da crotalfina 50

4.7 Avaliação da ativação de receptores opióides e canabinóides após o tratamento local com crotalfina

4.8 Participação de endocanabinóides e opióides endógenos no efeito da crotalfina ........55

4.8.1 Envolvimento de endocanabinóides no efeito da crotalfina ...........................................55

4.8.2 Envolvimento de opióides endógenos no efeito da crotalfina .......................................58

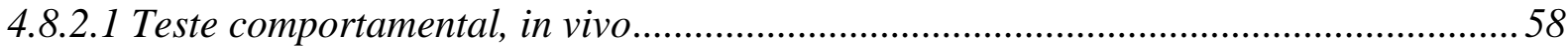

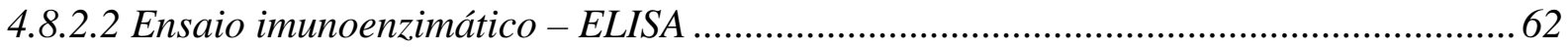

4.9 Atividade da crotalfina sobre os receptores canabinóides......................................63

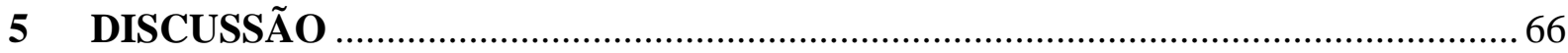

6 CONCLUSÃO

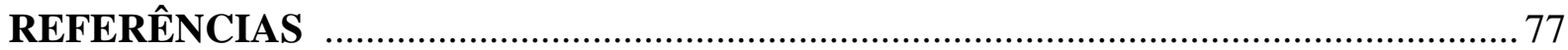




\section{INTRODUÇÃO}

A dor é um fenômeno que afeta todas as pessoas, independente de raça, cor, sexo ou idade, em alguma fase de sua vida. E apesar dos avanços obtidos nos últimos anos em relação ao entendimento dos mecanismos envolvidos na gênese, processamento e transmissão dos impulsos dolorosos, bem como do seu controle, muitas pessoas ainda sofrem com tratamentos que não são totalmente efetivos ou ainda com efeitos adversos severos de alguns tratamentos. Apesar das diversas opções existentes para o tratamento da dor, entre fármacos e outras terapias, os opióides ainda estão entre os fármacos mais utilizados para o tratamento de processos dolorosos, principalmente em relação às dores persistentes.

\subsection{Dor e analgesia}

A transmissão da dor, da periferia para o SNC (nocicepção), está associada à atividade elétrica das fibras nervosas aferentes primárias, as quais possuem terminações sensoriais nos tecidos periféricos e são ativadas por estímulos mecânicos, térmicos e químicos. Os neurônios aferentes primários desempenham três funções principais no que diz respeito à nocicepção: 1detecção do estímulo nociceptivo ou nocivo (transdução); 2- condução do impulso da periferia para a medula espinhal; 3- transferência sináptica desses implusos para neurônios presentes em lâminas específicas do corno dorsal da medula espinhal (transmissão) (CAVIEDES; HERRANZ, 2002).

Muitas destas fibras nervosas aferentes são denominadas nociceptores polimodais (fibras C), possuindo baixa velocidade de condução, por não apresentarem mielina. As fibras nociceptivas mielinizadas, denominadas $A \delta$, conduzem mais rapidamente os estímulos periféricos. As fibras nociceptivas terminam nas camadas superficiais do corno dorsal da medula espinhal, formando conexões sinápticas com os neurônios da transmissão que se dirigem ao tálamo (BELMONTE; CERVERO, 1996; CARRANZANA, 1998; JULIUS; BASBAUM, 2001; RANG et al., 1997).

Os mediadores periféricos da dor atuam via receptores ligados a intermediários celulares regulatórios (proteína $\mathrm{G}$, segundos mensageiros), que regulam a permeabilidade da membrana e a concentração iônica celular (BEVAN, 1999; REICHLING; LEVINE, 1999). A resposta hipernociceptiva está baseada no desequilíbrio entre os níveis intracelulares de AMPc e GMPc, que ocorre quando o receptor esta inativo. $\mathrm{Na}$ vigência de hipernocicepção, ocorre incremento das concentrações intracelulares de AMPc, ativação de proteínoquinases, como 
PKA e fosforilação de canais iônicos, aumento do influxo de $\mathrm{Ca}^{2+}$ intracelular, despolarização da membrana celular e transmissão do impulso nervoso (CUNHA et al., 1999; ENGLAND et al., 1996; FERREIRA, 1994). Alguns mediadores hipernociceptivos elevam diretamente as concentrações intracelulares de AMPc mas outros, cujos receptores não estão acoplados a adenilato ciclase, sensibilizam nociceptores por mecanismos independentes da formação direta do AMPc. Estes mecanismos incluem a geração de prostanóides e a ativação de proteínoquinase C (PKC) (BEVAN, 1999). A ativação da PKC acarreta a fosforilação e o aumento da atividade de canais iônicos permeáveis a $\mathrm{Ca}^{2+}$ e $\mathrm{Na}^{+}$(JULIUS; BASBAUM, 2001; LORENZETTI; FERREIRA, 1996; MILLAN, 1999).

Tem sido proposta ainda, uma via de sinalização intracelular adicional, a via das MAPKs, que pode ser ativada independentemente da ativação da PKC ou PKA (DINA et al., 2003). A cascata das MAPKs é ativada pela fosforilação de resíduos de tirosina e treonina (JI; WOOLF, 2001), sendo subdividida em 3 membros: quinases reguladas por sinais extracelulares (ERKs), quinase N-terminal c-Jun (JNK) e a p-38 MAPK. Dai e colaboradores (2002) demonstraram a participação das MAPKs, mais especificamente das ERKs, em processos hipernociceptivos (DAI et al., 2002). Independentemente do mecanismo de sinalização intracelular, o aumento na expressão e fosforilação de canais iônicos em membranas de neurônios periféricos é o principal fator responsável pelo aumento da excitabilidade da membrana destas células (WOOLF, 2000). Os principais canais iônicos responsáveis pela geração de potenciais de ação na membrana de neurônios nociceptivos são os canais de sódio e cálcio dependentes de voltagem (SAEGUSA et al., 2002; VANEGAS; SCHAIBLE, 2000; WOOLF, 2004).

O corno dorsal da medula espinhal é um sítio importante no processo de transmissão da informação nociceptiva da periferia para o SNC. Muitos neurotransmissores estão envolvidos na modulação desta transmissão neste sítio medular (AIMONE; YAKSH, 1989). Estes neurotransmissores incluem, entre outros, aminoácidos excitatórios como o glutamato, e neurocininas como a substância P, a neurocinina A e o Peptídeo Relacionado ao Gene da Calcitonina (KIDD; URBAN, 2001; SCHAIBLE; RICHTER, 2004), os quais, atuando em receptores específicos na membrana celular de neurônios pós-sinápticos, favorecem a transmissão da informação nociceptiva e a geração da sensibilização central. A ativação de receptores NMDA para glutamato tem papel chave na indução e manutenção da sensibilização central (SCHAIBLE; RICHTER, 2004). Contudo, a liberação de neuropeptídeos, fatores neurotróficos e de prostaglandinas, neste sítio medular, também 
contribui para a gênese do processo de sensibilização central (BESSON, 1999; SCHAIBLE; RICHTER, 2004; WOOLF, 2000).

Com base nesses mecanismos, analgésicos podem ser divididos em dois grupos: a) os que previnem a sensibilização dos nociceptores (FERREIRA, 1972; 1973), como os antiinflamatórios não esteroidais e b) os que interferem direta ou indiretamente, com os receptores da dor já sensibilizados, como dipirona, opióides ou substâncias liberadoras de opióides endógenos (FERREIRA; LORENZETTI, 1995; FERREIRA et al., 1984; FERREIRA; NAKAMURA, 1979a; b; c; LORENZETTI; FERREIRA, 1982).

\subsection{Analgésicos Opióides}

Os opióides estão entre os analgésicos mais utilizados no controle da dor. Opióides exógenos (FERREIRA; NAKAMURA, 1979a; b; PRZEWLOCKI; PRZEWLOCKA, 2001; STEIN; ZOLLNER, 2009) e endógenos (STEIN; ZOLLNER, 2009; TRIGO et al., 2009) induzem marcado efeito antinociceptivo central e periférico, através da interação com receptores opióides presentes em nervos sensitivos no tecido inflamado (RACHINGERADAM et al., 2011; WALKER, 2003). Stein e colaboradores (STEIN et al., 1989) sugeriram o envolvimento de receptores periféricos na analgesia periférica, baseados na demonstração de que, em modelo de hiperalgesia inflamatória induzida pela administração intraplantar (i.pl.) de adjuvante de Freud em ratos, agonistas específicos destes receptores, injetados pela mesma via, acarretavam antinocicepção.

O termo opióide aplica-se a qualquer substância que produza efeitos semelhantes aos da morfina e que são bloqueados por antagonistas do tipo naloxona (FOLEY; INTURRISI, 1987; REISINE et al., 1996). Os opióides, por ação em receptores específicos, acarretam alteração da resposta neuronal a estímulos nociceptivos, induzindo analgesia em seres humanos e em animais (PRZEWLOCKI; PRZEWLOCKA, 2001; VANDERAH, 2007; YAKSH, 1999). Os receptores opióides apresentam 7 domínios transmembrânicos são acoplados à proteína G (GPCRs) e apresentam extensa homologia estrutural entre si (PRZEWLOCKI; PRZEWLOCKA, 2001; ZHANG et al., 2005). São conhecidas pelo menos 5 tipos de receptores opióides - mu ( $\mu$ ou MOP), delta ( $\delta$ ou DOP), kappa ( $\kappa$ ou KOP), epsilon $(\varepsilon)$ e sigma $(\sigma)$. Uma sexta classe de receptores, denominada nociceptina/orfanina FQ (NOP), cujo ligante natural é a nociceptina, tem sido proposta como integrante da família dos receptores opióides (BARLOCCO et al., 2000). No entanto, os principais efeitos analgésicos dos opióides são mediados por receptores opióides do tipo mu, kappa e delta. 
Os ligantes endógenos dos receptores opióides foram identificados como encefalinas, dinorfinas e endorfinas. Receptores $\kappa$ possuem afinidade elevada por dinorfina A, indicando ser este o ligante endógeno deste tipo de receptor. Por outro lado, estudos anatômicos têm sugerido não só afinidade, como também co-distribuição entre encefalinas e a expressão dos receptores $\delta$ e $\mu$ em muitas regiões do Sistema Nervoso. As beta-endorfinas, por sua vez, ligam-se diretamente a receptores $\mu$ e $\delta$ (PRZEWLOCKI; PRZEWLOCKA, 2001; REISINE et al., 1996).

Os receptores opióides estão amplamente distribuídos no Sistema Nervoso Central (SNC) (BODNAR, 2002; WITTERT et al., 1996), em regiões como tálamo, córtex cerebral, amígdala, núcleo acumbens, substância nigra, formação reticular e substância cinzenta periaquedutal mesencefálicas, além de serem encontrados na medula espinhal (PRZEWLOCKI; PRZEWLOCKA, 2001; VANDERAH, 2007; YAKSH, 1999). Na periferia, são encontrados em tecidos e em células, sendo que estudos farmacológicos, neurofisiológicos e imunohistológicos têm comprovado que os opióides acarretam analgesia periférica, através da interação com receptores opióides presentes em nervos sensitivos no tecido inflamado (BODNAR, 2002; WITTERT et al., 1996; YAKSH, 1999)

Diversos mecanismos moleculares estão envolvidos na ação analgésica dos opióides. Estes mecanismos incluem a abertura de canais de potássio, com consequente hiperpolarização da membrana celular e/ou a inibição do sistema da adenilciclase, diminuindo a produção de AMPc (SCHULTZ; GROSS, 2001) e impedindo a abertura dos canais de cálcio. A redução do influxo de cálcio nas fibras nervosas acarreta inibição da liberação de neurotransmissores, contribuindo para a diminuição da transmissão do impulso nervoso (DICKENSON; SULLIVAN, 1987; VANDERAH, 2007).

Os receptores opióides estão predominantemente acoplados a proteínas Gi/G0 (GARZON et al., 1998). A ativação dos receptores opióides acarreta interação das subunidades $\alpha$ e $\beta \gamma$ da proteina $\mathrm{G}$, com vários sistemas efetores celulares, modulando uma série de vias de sinalização intracelular. Por exemplo, foi observado ainda, em experimentos in vitro, utilizando diferentes linhagens de células em cultura, que a ativação de receptores opióides acarreta ativação da via das MAPKs (BELCHEVA et al., 2005; BELCHEVA et al., 1998; BOHN et al., 2000; BRUCHAS et al., 2006) e que a ativação diferencial de uma ou outra das enzimas que compõem esta via parece ser importante para os efeitos de alguns agonistas opióides. Dentre essas enzimas, incluem-se diferentes cascatas de quinases, tais 
como proteína quinase $\mathrm{C}$ (PKC), calmodulina quinase II (CaM quinase II), proteína quinase $\mathrm{B}$ (Akt) e MAP quinases (LOHSE et al., 1990; WILLIAMS et al., 2001).

Dados de literatura mostram também, que a ativação da via L-arginina-óxido nítricoGMPc é responsável pela analgesia periférica induzida por alguns opióides ou substâncias liberadoras de opióides endógenos, uma vez que inibidores da enzima óxido nítrico sintase (NOS) ou da guanilato ciclase revertem o efeito destes fármacos (AMARANTE; DUARTE, 2002; FERREIRA, 1990; FERREIRA; LORENZETTI, 1995; GRANADOS-SOTO et al., 1997; SACHS et al., 2004). Recentemente foi demonstrada a participação da via PI3K $\gamma / \mathrm{AKt}$ na síntese de óxido nítrico induzida pela morfina, protótipo de fármacos opióides (CUNHA et al., 2010).

Como dito anteriormente, analgésicos opióides estão classificados entre aqueles capazes de interferir direta ou indiretamente, com os receptores da dor já sensibilizados (FERREIRA; LORENZETTI, 1995; FERREIRA et al., 1984; FERREIRA; NAKAMURA, 1979a; b; c; LORENZETTI; FERREIRA, 1982), sendo seu principal representante a morfina. A morfina, agonista preferencial de receptores $m u$, é um fármaco amplamente utilizado no controle de dores crônicas e severas. Apesar disto, ainda existe certa resistência ao seu uso, devido aos efeitos indesejáveis associados à sua administração, entre eles depressão respiratória, euforia, dependência e sedação (BODNAR, 2009). Outro efeito adverso comumente observado após o uso de opióides é o fenômeno de hiperalgesia (aumento da sensibilidade a dor), que pode ocorrer agudamente, após administração de baixas doses, ou tardiamente, subsequente ao término do efeito analgésico, e que pode contribuir para o desenvolvimento de tolerância ao efeito analgésico destes fármacos. Este fenômeno não parece estar relacionado ao estímulo doloroso original. Sendo assim, apesar do importante efeito analgésico, os fármacos opióides acarretam esses vários efeitos adversos, o que faz com que a utilização desses fármacos seja muitas vezes limitada (JENSEN et al., 2009).

Consequentemente, tem sido grande a busca por novos medicamentos opióides com um menor número de efeitos indesejáveis. Estas pesquisas tem se concentrado em encontrar opióides com ação periférica ou ainda agonistas de receptores kappa e delta, uma vez que a maioria dos efeitos adversos dos opióides é decorrente da ação em receptores mu (BODNAR, 2009; RACHINGER-ADAM et al., 2011; VADIVELU et al., 2011). 


\subsection{Estudos sobre a crotalfina e sua interação com o sistema opióide}

No sentido de buscar novos medicamentos opióides com um número menor de efeitos adversos, foi demonstrado recentemente o efeito antinociceptivo da crotalfina, um peptídeo de 14 aminoácidos (Figura 1) contendo uma ponte dissulfídica e um ácido piroglutâmico, com ação analgésica tipo opióide, sintetizado a partir da sequência de um composto analgésico purificado do veneno de serpentes Crotalus durissus terrificus (KONNO et al., 2008).

\section{Figura 1 - Seqüência de aminoácidos da crotalfina.}

\section{$<$ EFSPENCQGESQPC}

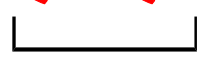

Fonte: (KONNO et al., 2008)

O isolamento, caracterização e seqüenciamento da crotalfina são resultantes de anos de estudo sobre o efeito antinociceptivo do veneno da serpente Crotalus durissus terrificus (VCdt). Nestes estudos, quando avaliado nos modelos de hiperalgesia induzida por prostaglandina $E_{2}$ ou hiperalgesia inflamatória induzida por carragenina, foi demonstrado que o VCdt era capaz de acarretar antinocicepção central e periférica, de longa duração, mediado pela ativação de receptores opióides. O efeito central, investigado no modelo da placa-quente, era de longa duração (5 dias) e mediado pela ativação de receptores opióides do tipo kappa (BRIGATTE et al., 2001; GIORGI et al., 1993). O efeito do VCdt também é mediado pela estimulação do óxido nítrico sintetizado a partir da óxido nítrico sintase neuronal, pelo GMPc (e parcialmente da PKG) e por canais para $\mathrm{K}^{+}$dependentes de ATP (CHACUR et al., 2003; PICOLO et al., 2003; PICOLO; CURY, 2004; PICOLO et al., 2000). Ainda, no modelo de hiperalgesia induzida por carragenina, não era observada tolerância ao efeito analgésico, mesmo para o veneno administrado diariamente por até 15 dias (PICOLO et al., 2003; PICOLO et al., 2000).

O veneno também era capaz de acarretar antinocicepção em modelos de dor crônica, como a dor de câncer e a dor neuropática induzida pela constrição crônica do nervo ciático de ratos. Nestes modelos, o efeito antinociceptivo era mediado também pela ativação simultânea de receptores periféricos kappa e delta opióides, contudo a importância de cada receptor para a atividade analgésica era dependente do modelo utilizado (BRIGATTE, 2005; GUTIERREZ, 
2005). No modelo de dor neuropática, o efeito observado também era de longa duração (3 dias após a administração de uma única dose do VCdt) (GUTIERREZ, 2005).

Figura 2 - Extração do veneno bruto de serpentes Crotalus durissus terrificus.

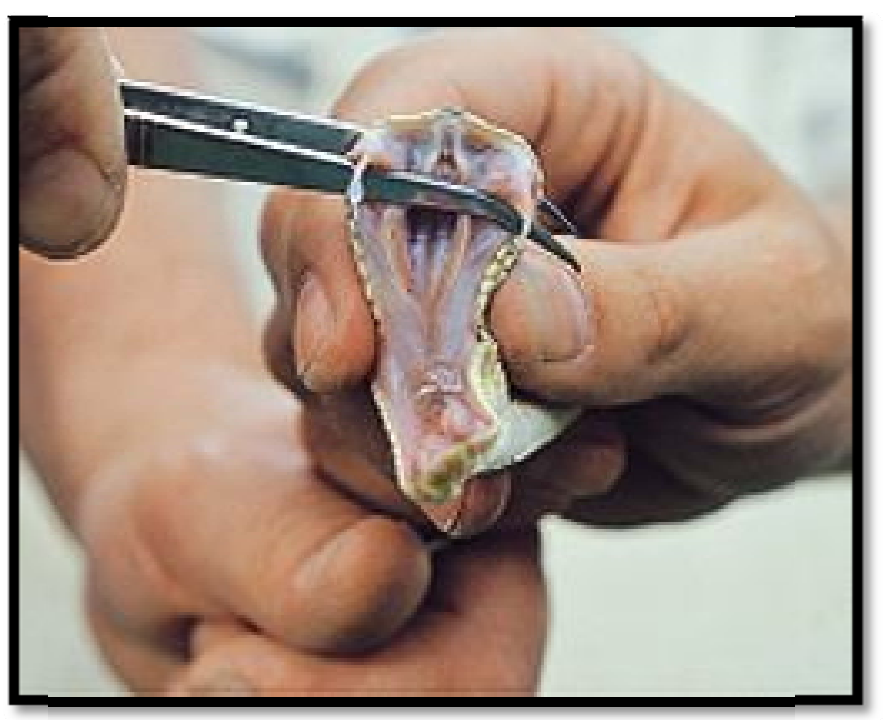

Fonte: (CURY; PICOLO, 2006)

A partir destes dados, foram iniciados os estudos para obtenção do composto analgésico presente neste veneno que resultaram na purificação, isolamento e identificação do fator analgésico natural presente no VCdt. A partir da seqüencia de aminoácidos deste fator, a crotalfina foi sintetizada por síntese química manual (KONNO et al., 2008).

Os estudos realizados com a crotalfina demonstraram que ela era capaz de reproduzir os dados obtidos com o veneno bruto. Os resultados demonstram que ela é capaz de induzir antinocicepção de longa duração por via oral e intraplantar, de maneira dose-dependente. Este efeito pode ser observado no modelo de hiperalgesia induzida por $\mathrm{PGE}_{2}$, quando administrada por vias sistêmicas - oral e endovenosa, ou por via local - intraplantar (KONNO et al., 2008). O efeito antinociceptivo é também observado no modelo de hiperalgesia inflamatória induzida por carragenina e em modelos experimentais de dor crônica - dor de câncer e dor neuropática (BRIGATTE, 2005; GUTIERREZ et al., 2008; KONNO et al., 2008). Em todos os modelos, o efeito é de longa duração (2-3 dias nos modelos de dor crônica e até 5 dias no modelo de hiperalgesia inflamatória) e mediado pela ativação de receptores opióides periféricos do tipo $\kappa$ (modelos agudos) ou $\kappa$ e $\delta$ (modelos crônicos) (GUTIERREZ et al., 2008; KONNO et al., 2008) e pela ativação da via L-arginina-NO-GMPc (GUTIERREZ et al., 2012). 
Estudos realizados pelo nosso grupo evidenciaram também que a potência e a longa duração de ação da crotalfina são detectadas na presença de um estímulo inflamatório (carragenina), de sensibilização por prostaglandina $E_{2}$ ou de neuropatia, uma vez que na ausência destes estímulos, o efeito antinociceptivo é de menor intensidade e detectado por apenas 5 horas (Pereira, L. \& Cury, Y., manuscrito em preparação). Ainda, foi demonstrado que a sensibilização previa por prostaglandina $\mathrm{E}_{2}$ ou lesão nervosa, aumenta a expressão de receptores opióides no gânglio da raiz dorsal e no nervo da pata de ratos, e que a crotalfina é capaz de alterar o estado conformacional destes receptores (indicativo de ativação), sendo esta alteração de maior magnitude, na presença de sensibilização previa (Zambelli et al, submetido). Este fenômeno pode contribuir para a detecção da maior efetividade da crotalfina na vigência de inflamação/lesão tecidual.

Estes mesmos estudos de Zambelli e colaboradores mostraram ainda (dados preliminares) que a crotalfina ativa a via das MAPKs (ERK1/2 e JNK) em neurônios do DRG, evento este que é dependente da pré-sensibilização com $\mathrm{PGE}_{2}$, da ativação do receptor opióide do tipo $\mathrm{K}$ e da proteína quinase $\mathrm{C} \zeta$. Outros resultados preliminares do nosso grupo demonstram a participação das MAPKs no efeito antinociceptivo da crotalfina também em modelos in vivo. Estes testes confirmam que as quinases ERK e JNK estão envolvidas na ação do peptídeo, uma vez que a administração intratecal dos inibidores destas quinases, mas não do inibidor da via da p38, reverteram a antinocicepção induzida pela crotalfina em ensaios in vivo (Pereira, L. \& Cury, Y., manuscrito em preparação).

$\mathrm{O}$ tratamento prolongado com o peptídeo sintético não acarreta o desenvolvimento de tolerância ao efeito antinociceptivo, quando avaliado em modelo de dor neuropática (GUTIERREZ et al., 2008). Ainda, diferentemente do observado com a morfina, na clínica médica e em estudos experimentais (CELERIER et al., 2000; COMPTON et al., 2003; GUIGNARD et al., 2000), a administração de crotalfina em ratos, em doses sub-analgésicas, não induz o aparecimento de hiperalgesia ou, quando administrada em doses analgésicas, não acarreta o desenvolvimento de hiperalgesia tardia, subseqüentemente ao fim do efeito analgésico (Pereira \& Cury, comunicação pessoal).

É importante ressaltar que, apesar de acarretar analgesia revertida por antagonistas de receptores opióides, a sequência da crotalfina não apresenta similaridade com nenhum outro opióide conhecido (KONNO et al., 2008). Ainda, estudos preliminares indicam que a crotalfina não age diretamente nos receptores opióides, uma vez que o peptídeo não é capaz de deslocar naloxona marcada $\left(\left[{ }^{3} \mathrm{H}\right]\right.$ naloxone) em estudos de "binding" (Correa, F., comunicação pessoal). Assim, buscamos neste projeto investigar quais mecanismos estariam 
envolvidos na antinocicepção induzida pela crotalfina, avaliando a participação de receptores canabinóides neste efeito, uma vez que tem sido sugerida uma estreita relação entre os sistemas opióides e canabinóides.

\section{Figura 3 - Crotalus durissus terrificus}

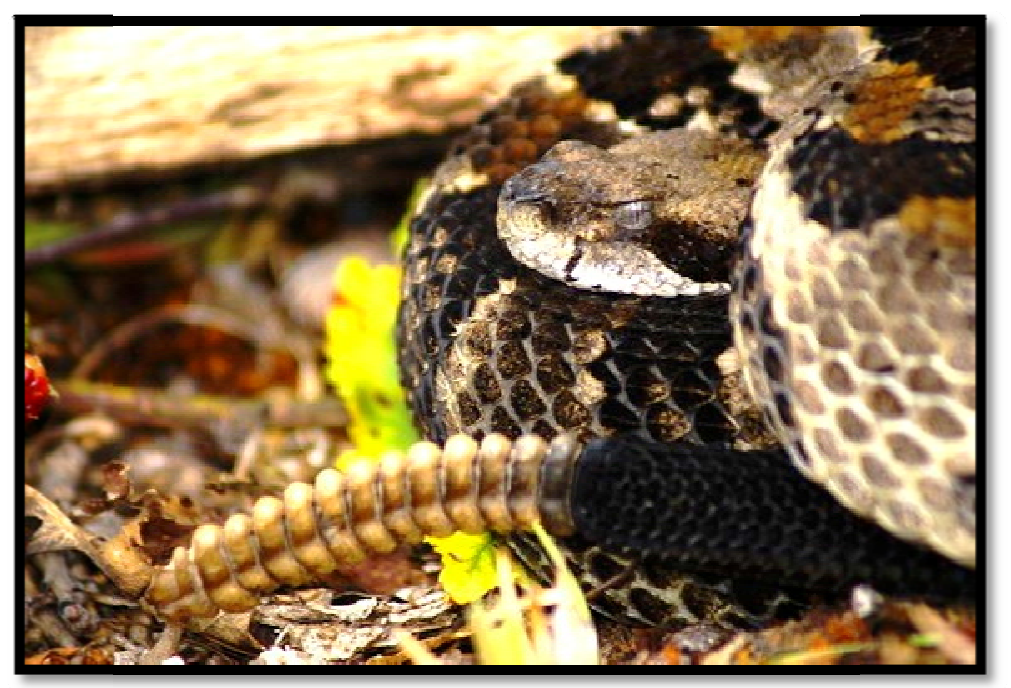

Fonte: (CURY; PICOLO, 2006)

\subsection{Canabinóides e seus receptores}

Com relação à busca por novos compostos analgésicos, muitos estudos têm chamado atenção para a Cannabis sativa, devido ao seu potencial analgésico e pela sua capacidade de aliviar sintomas relacionados com desordens do sistema nervoso central (BONFA et al., 2008; ZUARDI, 2006). E a partir da década de 90, após a descrição dos receptores canabinóides e de um sistema canabinóide endógeno no cérebro, houve um aumento no interesse dos pesquisadores, bem como uma diminuição do preconceito pelo assunto. Assim, principalmente na última década, vários dados têm sido obtidos a respeito da farmacologia dos canabinóides (BONFA et al., 2008). Além do seu princípio ativo, o delta- ${ }^{9}$ tetrahidrocanabinol ( $\Delta^{9}$-THC), a Cannabis sativa contém outras 65 substâncias, chamadas fitocanabinóides (BONFA et al., 2008).

Atualmente, dois tipos de receptores canabinóides são conhecidos: $\mathrm{CB}_{1}$, clonado em 1990, e $\mathrm{CB}_{2}$, clonado em 1993. Um terceiro receptor, chamado de GPR55, foi caracterizado como não- $\mathrm{CB}_{1}$ e não- $\mathrm{CB}_{2}$, porém se liga seletivamente a ligantes canabinóides endógenos, naturais e sintéticos já conhecidos (BAKER et al., 2006). Entretanto, estudos adicionais são 
necessários para identificar o receptor GPR55 como membro da família de receptores canabinóides, ou receptor $\mathrm{CB}_{3}$ (PERTWEE, 2010).

Os receptores $\mathrm{CB}_{1}$ são amplamente expressos em diversas estruturas encefálicas, medula espinal, gânglios da medula dorsal, sistema nervoso entérico, adipócitos, células endoteliais, hepatócitos, tecido muscular e trato gastrointestinal. Pode-se considerar que os receptores $\mathrm{CB}_{1}$ encontram-se distribuídos amplamente por todo o cérebro e em níveis comparáveis aos encontrados para os receptores ligados a canais iônicos, sendo considerados os receptores acoplados à proteína $\mathrm{G}$ de maior abundância no SNC (HERKENHAM et al., 1990; HOWLETT et al., 2004). Concentrações particularmente altas de receptores $\mathrm{CB}_{1}$ foram encontradas nos gânglios da base (substância negra, estriado e globo pálido), no cerebelo, córtex, amígdala e hipocampo, regiões cerebrais que estão relacionadas com os efeitos comportamentais conhecidos dos canabinóides (HERKENHAM et al., 1990). Níveis mais baixos de receptores $\mathrm{CB}_{1}$ foram encontrados no hipotálamo e na medula espinhal, sendo praticamente ausentes nos centros respiratórios do tronco cerebral, de acordo com as observações clínicas de baixíssima letalidade para a overdose de canabinóides (HOWLETT et al., 2004). Estudos de imunohistoquímica confirmaram as localizações encefálicas dos receptores $\mathrm{CB}_{1}$ e enfatizaram que altos níveis de receptores $\mathrm{CB}_{1}$ são encontrados nas fibras axonais, especialmente na extremidade terminal (KATONA et al., 2000). Mais detalhadamente, estudos utilizando microscopia eletrônica em fatias de hipocampo descreveram que os receptores $\mathrm{CB}_{1}$ nesta preparação são encontrados quase que exclusivamente em terminais neuronais pré-sinápticos de neurônios GABAérgicos e de colecistocinina (CCK) (HAJOS et al., 2000; KATONA et al., 2000). Outro estudo em tecido hipocampal demonstrou que os receptores $\mathrm{CB}_{1}$ são expressos em toda a membrana do terminal pré-sináptico, com exceção da zona ativa, enquanto estudos de tecido do estriado demonstraram uma expressão mais abrangente dos receptores $\mathrm{CB}_{1}$, incluindo elementos póssinápticos e glia (RODRIGUEZ et al., 2001).

Fora do sistema nervoso os receptores $\mathrm{CB}_{1}$ podem ser encontrados em tecidos periféricos como as glândulas pituitária e adrenal, células do sistema imune, medula óssea, coração, pulmões, timo, fígado, e tecidos de órgãos reprodutivos como a próstata e os testículos (GALIEGUE et al., 1995; HOWLETT et al., 2004; PERTWEE, 2001).

Já os receptores $\mathrm{CB}_{2}$ estão presentes predominantemente no sistema periférico, e se relacionam com o sistema imunológico, células $\mathrm{T}$, células $\mathrm{B}$, baço e amígdalas (AMERI, 1999; MARTIN; LICHTMAN, 1998). Por consequencia, estão intimamente ligados a funções do sistema imune onde regulam a liberação de citocinas e a migração de células do sistema 
imune, podendo ser encontrados em diversos tecidos linfóides dentro ou fora do SNC (FERNANDEZ-RUIZ et al., 2007; PERTWEE, 2001). Ensaios de hibridização in situ demonstraram a existência de RNAm para os receptores $\mathrm{CB}_{2}$ no fígado, timo, amígdalas, medula óssea, pâncreas, assim como em macrófagos, monócitos e em uma ampla variedade de células imunes em cultura (LYNN; HERKENHAM, 1994). RNAm para os receptores canabinóides $\mathrm{CB}_{2}$ também foi encontrado em tecido glial de córtex retirados de ratos recémnascidos, inclusive em concentrações mais elevadas do que os níveis de RNAm para os receptores $\mathrm{CB}_{1}$ encontrados na mesma preparação, demonstrando uma possível função dos receptores $\mathrm{CB}_{2}$ no desenvolvimento cerebral (CABRAL et al., 2001). Além do mais, estudo recente demonstrou enfaticamente a presença de receptores $\mathrm{CB}_{2}$ funcionais no córtex, cerebelo e tronco cerebral de ratos, validadas farmacologicamente in vivo utilizando antagonistas seletivos para ambos os receptores $\mathrm{CB}_{1}$ e $\mathrm{CB}_{2}$ em um modelo animal de atividade anti-emética do $\Delta^{9}$-THC (VAN SICKLE et al., 2005).

Ambos os receptores canabinóides $\mathrm{CB}_{1}$ e $\mathrm{CB}_{2}$ são receptores acoplados à proteína $\mathrm{Gi} / \mathrm{o}$ e exercem seus efeitos fisiológicos pela inibição da atividade da adenilato ciclase, com conseqüente diminuição dos níveis intracelulares de AMPc (FELDER et al., 1995). Além disso, a ativação de receptores canabinóides pode dar início a uma cascata de ativação de proteínas quinases ativadas por mitógeno (MAPk) (BOUABOULA et al., 1995) e sinalização mediada por genes de expressão rápida, como c-FOS (PATEL et al., 1998) e a quinase Nterminal do c-Jun (JNK) (RUEDA et al., 2000). Os receptores $\mathrm{CB}_{1}$ também podem aumentar a condutância de canais de potássio (FELDER et al., 1995) ou diminuir a condutância de canais de cálcio atuando indiretamente pela ativação de proteína $G$ e produção de segundos mensageiros (FELDER et al., 1995; GEBREMEDHIN et al., 1999)

Por outro lado, os receptores $\mathrm{CB}_{2}$ também podem exercer seu efeito através da trandução de sinal via uma outra proteína heterodimérica $G$, chamada $G_{q}$, ativando a fosfolipase C, que quebra o fosfatidilinositol 4,5-bifosfato (PIP2) em inositol trifosfato (IP3) e diacilglicerol (DAG). O IP3 interage com os canais de cálcio do retículo sarcoplasmático, liberando o cálcio que estava retido para o citoplasma. O cálcio, por sua vez, aciona todos o outros efeitos (FERNANDEZ-RUIZ et al., 2007).

Apesar deste resumo geral dos efeitos da ativação de receptores canabinóides, já se tem notícia de que seus efeitos podem variar enormemente dependendo do tecido e tipo celular onde são expressos. Também já são conhecidos os ligantes endógenos destes receptores, sendo os principais a aracdonil-etanolamida (AEA), também conhecida como anandamida, e o 2-aracdonil-glicerol (2-AG). Assim como as substâncias presentes na 
Cannabis, os canabinóides de mamíferos são de natureza lipídica (MARTIN; LICHTMAN, 1998). A partir deles, vários outros compostos com estruturas químicas bastante diferentes e que ativam os receptores canabinóides vêm sendo pesquisados e sintetizados, mas os mecanismos de interação entre estes compostos e os receptores canabinóides ainda não são completamente conhecidos.

Diferentemente dos neurotransmissores clássicos, os endocanabinóides são considerados mensageiros atípicos, uma vez que medeiam a transferência das informações dos terminais pós aos pré-sinápticos de uma forma retrógrada. Ainda, são sintetizados sob demanda e não são armazenados em vesículas (DI MARZO et al., 2004). A síntese de endocanabinóides ocorre nos neurônios pós-sinápticos após o influxo de cálcio e a subseqüente ativação das fosfolipases (fosfolipase D no caso da anandamida e diaciglicerol lipase no caso da 2-AG), que convertem os fosfolipídeos em endocanabinóides. Eles parecem atingir imediatamente a fenda sináptica por meio da difusão livre ou assistida e se acoplar aos receptores pré-sinápticos. Por meio de uma rede complexa de processos de sinalização intracelular, a ativação dos receptores canabinóides resulta finalmente em uma diminuição no influxo de cálcio nos terminais axônicos e, dessa forma, na diminuição da liberação de transmissores responsáveis em continuar conduzindo a informação dolorosa, tais como, subtância $\mathrm{P}$ e glutamato. Ademais da ativação de receptores canabinóides, a ativação dos receptores TRPV1 pela anandamida leva à despolarização aumentada das membranas póssinápticas. Portando, a ativação de receptores $\mathrm{CB}_{1}$ e do TRPV1 parece exercer efeitos opostos (DI MARZO et al., 1999; DI MARZO et al., 1994; MECHOULAM et al., 1998).

Assim como no caso dos neurotransmissores clássicos, as ações dos endocanabinoides são limitadas por um processo em duas etapas: internalização, seguida por catabolismo. A primeira etapa ainda não está clara, já que há debate sobre se a internalização dos endocanabinoides ocorre passivamente por meio da difusão ou por transportadores específicos. Após a internalização, os endocanabinoides sofrem hidrólise enzimática (MECHOULAM et al., 1998).

As principais enzimas responsáveis pela hidrólise da anandamida e da 2-AG são a amida hidrolase de ácidos graxos (FAAH) e a lipase monoacilglicerol (MAGL), respectivamente. É intrigante que os dois endocanabinoides sejam degradados tanto de forma pré-sináptica (2-AG) como pós-sináptica (anandamida). Tanto a FAAH quanto a MAGL emergiram como importantes alvos farmacológicos com potencial terapêutico promissor (DI MARZO et al., 2004; PIOMELLI, 2003; WALKER; HUANG, 2002). 
Além dos receptores de membrana já mencionados, dados da literatura indicam que um ou mais ligantes do receptor de $\mathrm{CB}_{1} / \mathrm{CB}_{2}$ pode alvejar também locais alostéricos sobre receptores acoplados à proteína $\mathrm{G}$, canais iónicos e receptores nucleares. Como exemplo, pode-se citar o GPR55, receptores $\beta$-adrenérgicos, serotoninérgicos, muscarínicos, nicotínicos, opióides, os receptores de adenosina e imidazolina-like, receptores glutamatérgicos ionotrópicos, receptores de glicina, canais de cálcio, de potássio, de sódio, canais TRPV1, TRPV2, TRPA1 e os receptores nucleares (particularmente PPAR $\alpha$ and PPAR $\gamma$ ) (PERTWEE, 2010).

Sobre as evidências de que os endocanabinóides possam agir em receptores nucleares para lipídeos (O'SULLIVAN, 2007), vale recordar que receptores PPAR pertencem a uma família de receptores nucleares, com três isoformas: $\alpha, \delta$ e $\gamma$. Estes receptores se heterodimerizam com receptores retinóide $\mathrm{X}$ e se ligam a elementos responsivos a PPAR no DNA, levando à transcrição gênica. Entre as diversas classes de transmissores que atuam nos PPAR estão os ácidos graxos e seus derivados, de maneira que não surpreende que estes receptores possam participar da sinalização endocanabinóide.

Apesar dos estudos recentes demonstrando eficácia da Cannabis sativa no tratamento da êmese, glaucoma, anorexia, obesidade, esclerose múltipla, entre outros, seu uso continua limitado, devido a uma série de efeitos indesejáveis, relacionados as suas propriedades psicotrópicas. Têm sido descrito, entre outros efeitos, a dificuldade de concentração, prejuízo da memória, euforia, confusão de pensamentos, sonolência, relaxamento, instabilidade no andar, alteração da memória imediata, diminuição da capacidade para a realização de tarefas que requeiram operações múltiplas e variadas, lentidão na capacidade de reação e déficit na aptidão motora (AMERI, 1999; ANAND et al., 2009; BONFA et al., 2008; PINI et al., 2012).

Nesse sentido, os estudos referentes às propriedades analgésicas dos canabinóides têm se concentrado preferencialmente, mas não exclusivamente, nos receptores $\mathrm{CB}_{2}$, uma vez que estes estão presentes principalmente na periferia, sendo que drogas que atuem nesses canais poderiam acarretar menor número de efeitos indesejáveis (AMERI, 1999; ANAND et al., 2009; MARTIN; LICHTMAN, 1998).

\subsection{Propriedades analgésicas dos canabinóides e sua interação com opióides}

No século XIX, a maconha foi largamente utilizada para o alívio da dor (BONFA et al., 2008). Recentemente, esta propriedade voltou a ser intensamente estudada. Na história, diversos compostos, inicialmente alucinógenos, como o ópio, foram posteriormente utilizados 
como analgésicos. Este foi o ponto de partida para modificações estruturais nas moléculas de canabinóides, visando aumentar a atividade analgésica e diminuir a dependência causada pela droga (BONFA et al., 2008). Diversos estudos têm comprovado a eficácia analgésica dos canabinóides. Como exemplo, o $\Delta^{9}$-THC, o maior psicoativo da Cannabis, é capaz de induzir analgesia até 10 vezes maior que a morfina, em modelos animais tanto de dor aguda quanto neuropática. Este mesmo efeito tem sido observado também para outros canabinóides sintéticos (CICHEWICZ, 2004).

Modelos animais têm sido utilizados para investigar e confirmar esta antinocicepção, bem como para avaliar os mecanismos envolvidos neste efeito. Através desses modelos, tem sido demonstrada a capacidade dos canabinóides em suprimir a resposta comportamental após estimulação nociceptiva (ANAND et al., 2009; BONFA et al., 2008). Esta resposta antinociceptiva tem sido demonstrada para agonistas não-seletivos ou seletivos de $\mathrm{CB}_{1}$ e $\mathrm{CB}_{2}$ (BURGOS et al., 2009; GUERRERO et al., 2008; MALAN et al., 2001), tanto em animais (MALAN et al., 2001) como em condições clínicas (WALLACE et al., 2007), em diferentes tipos de dor, tanto aguda, incluindo modelos inflamatórios (BURGOS et al., 2009; COX et al., 2007), quanto crônica (GUERRERO et al., 2008; SAGAR et al., 2005).

Como dito anteriormente, vários dados da Literatura têm proposto uma estreita relação entre os sistemas opióides e canabinóides (DESROCHES; BEAULIEU, 2011). Tanto os receptores opióides quanto os canabinóides produzem antinocicepção através de mecanismos dependentes de proteína $\mathrm{G}$, que bloqueiam a liberação de neurotransmissores nociceptivos no cérebro e na medula espinhal (ANAND et al., 2009; CICHEWICZ, 2004; WELCH, 2009). Ambos os sistemas atuam em locais comuns, sendo que seus receptores estão co-distribuídos em áreas importantes para o controle da dor como o corno dorsal da medula espinhal, substância cinzenta periaquedutal, núcleo da rafe e núcleo talâmico centro-medial. Estes sistemas, ainda, parecem potencializar um ao outro, indicando uma interação sinérgica entre eles (CICHEWICZ, 2004; PAROLARO et al., 2011).

Estudos comportamentais e moleculares sobre este sinergismo demonstram que agonistas canabinóides induzem a liberação de opióides endógenos da mesma maneira que agonistas opióides podem induzir a liberação de endocanabonóides (IBRAHIM et al., 2005; WELCH; EADS, 1999). Outras formas de interação farmacológica entre esses dois sistemas também são relatados, por exemplo, a existência de uma interação direta receptor-receptor em células onde receptores opióides e canabinóides são co-expressos e a interação entre seus alvos intracelulares (DESROCHES; BEAULIEU, ; PAROLARO et al.). 
Tem sido relatado que a naloxona, um antagonista opióide não seletivo, previne efeito analgésico do AM1241, agonista seletivo para $\mathrm{CB}_{2}$, mostrando a participação de receptores opióides no efeito antinociceptivo de canabinóides (ANAND et al., 2009; IBRAHIM et al., 2005). Estudos semelhantes também têm sido realizados, utilizando antagonistas específicos de receptores opióides. Estes estudos têm mostrado, por exemplo, que o NorBNI, um antagonista de receptor opióide do tipo kappa, administrado por via intratecal, bloqueia o efeito antinociceptivo do $\Delta^{9}$-THC (SMITH et al., 1994; WELCH; EADS, 1999). Além disso, o anticorpo para dinorfina A também antagoniza o efeito antinociceptivo do $\Delta^{9}$-THC, sugerindo a contribuição do receptor kappa para a analgesia induzida por canabinóides, e demonstrando que o efeito dos canabinóides é dependente da liberação de opióides endógenos (BUSHLIN et al., 2009; MARTIN; LICHTMAN, 1998; PAROLARO et al., 2011).

Nesse sentido, a liberação de opióides endógenos por canabinóides tem sido demonstrada por diferentes autores (WELCH, 2009). Dados demonstram que o THC, administrado por via i.t. induz a liberação de opióides endógenos que estimulam tanto receptores kappa quanto delta (BUSHLIN et al., 2009; WELCH, 2009). Acredita-se ainda que o efeito sinérgico do $\Delta^{9}$-THC e morfina seja resultado não só da liberação de dinorfina $\mathrm{A}$, como também de $\beta$-endorfina, uma vez que o AM1241, agonista seletivo de receptores $\mathrm{CB}_{2}$ estimula liberação de $\beta$-endorfina em cultura de queratinócitos humanos, enquanto o AM630, antagonista de receptor $\mathrm{CB}_{2}$, inibe essa liberação. $\mathrm{O}$ anticorpo para $\beta$-endorfina também previne ação do agonista $\mathrm{CB}_{2}$, sugerindo que a antinocicepção mediada por ativação de $\mathrm{CB}_{2}$ está associada também à ativação de receptores opióides do tipo $\mu$ (IBRAHIM et al., 2005).

Dados recentes de Literatura têm demonstrado não só que drogas canabinóides são capazes de acarretar liberação de opióides endógenos, mas também que drogas opióides podem acarretar a liberação de endocanabinóides. Fonseca Pacheco e colaboradores (DA FONSECA PACHECO et al., 2008) demonstraram que tanto antagonistas de receptores $\mathrm{CB}_{1}$ como antagonistas de receptores $\mathrm{CB}_{2}$ são capazes de reverter analgesia induzida por morfina. Ainda, o MAFP (metil araquidonil fluorofosfonado), um inibidor da enzima que hidrolisa os endocanabinóides, potencializa a antinocicepção induzida pela morfina. 
Assim, baseado nos dados de literatura demostrando: (a) estreita relação entre o sistema canabinóide e o sistema opióide; (b) que agonistas canabinóides podem causar analgesia através da liberação de opióides endógenos e consequente ação destes em receptores opióides; (c) que a crotalfina acarreta analgesia periférica revertida por antagonistas opióides do tipo kappa e delta, e que (d) apesar do efeito antinociceptivo da crotalfina ser revertido por antagonistas opióides, estudos preliminares indicam que a crotalfina não ativa diretamente os receptores opióides uma vez que o peptídeo não é capaz de deslocar naloxona marcada $\left(\left[{ }^{3} \mathrm{H}\right]\right.$ naloxona) em estudos de "binding" (Correa, F., comunicação pessoal), o objetivo deste projeto é avaliar o possível efeito da crotalfina sobre o sistema canabinóide. 


\section{OBJETIVOS}

Baseado no texto exposto anteriormente, este projeto tem como objetivo avaliar o possível efeito da crotalfina sobre o sistema canabinóide, e a interação deste sistema com o sitema opióide.

Os objetivos específicos deste projeto são:

$\checkmark \quad$ Avaliar o efeito antinociceptivo da crotalfina sobre a hiperalgesia periférica aguda induzida por prostaglandina $\mathrm{E}_{2}$, em ratos, utilizando o modelo de pressão de pata;

$\checkmark \quad$ Avaliar a participação de receptores canabinóides $\mathrm{CB}_{1}$ e $\mathrm{CB}_{2}$ neste efeito;

$\checkmark \quad$ Avaliar a capacidade da crotalfina em ativar receptores canabinóides e opióides periféricos localizados no tecido plantar de ratos;

Avaliar se a ativação de receptores canabinóides e opióides induzida pela crotalfina ocorre indiretamente, devido liberação de endocanabinóides ou opióides endógenos;

Determinar se a liberação de opióides endógenos é decorrente da estimulação de receptores $\mathrm{CB}_{2}$ e se ela ocorre a partir de células periféricas presentes no tecido plantar dos animais; e

Determinar se a ativação de receptores canabinóides ocorre diretamente, decorrente de uma ligação com o receptor $\mathrm{CB}_{1}$ ou $\mathrm{CB}_{2}$. 


\section{MATERIAL E MÉTODOS}

\subsection{Animais}

Foram utilizados ratos Wistar, machos, com peso entre 160 a $180 \mathrm{~g}$, fornecidos pelo Biotério Central do Instituto Butantan (aprovado pela Comissão de Ética para Uso de Animais do Instituto Butantan - protocolo CEUAIB 622/09 e USP 029). Estes animais foram mantidos com água e ração ad libitum em sala apropriada, com isolamento acústico, temperatura controlada $\left(22^{\circ} \mathrm{C} \pm 1\right)$ e ciclo claro-escuro $(12: 12 \mathrm{~h})$, em caixas de microambiente, por um período mínimo de 3 dias antes dos experimentos.

\subsection{Indução da hiperalgesia por $\mathrm{PGE}_{2}$}

Uma solução estoque de $\mathrm{PGE}_{2}$ foi preparada, dissolvendo-se $500 \mu \mathrm{g}$ de prostaglandina $E_{2}$ em $1 \mathrm{ml}$ de etanol. No momento do uso, essa solução estoque foi novamente diluída em salina estéril, para a obtenção da dose de 100 ng/pata de $\mathrm{PGE}_{2}$. Ratos injetados com salina mais a proporção de etanol utilizada para diluição da $\mathrm{PGE}_{2}$, por via intraplantar (i.pl.), foram inicialmente utilizados como controles nos testes in vivo e demonstraram não induzir diferença significativa quando comparados com animais tratados com salina, pela mesma via. Portanto, nos testes comportamentais subseqüentes, os animais do grupo controle foram injetados com salina (i.pl.). Vale ressaltar que a solução com salina mais a proporção de etanol foi mantida e considerada em todos os testes ex vivo.

\subsection{Avaliação da sensibilidade dolorosa: Determinação da hiperalgesia}

Para avaliação da resposta hiperalgésica, foi utilizado o teste de pressão da pata de ratos (Analgesy-Meter Ugo Basile®, Itália), realizado de acordo com o método descrito por Randall and Sellito (RANDALL; SELITTO, 1957). Neste teste, uma força em gramas (g), de magnitude crescente (16 g/s), é continuamente aplicada sobre o dorso das patas posteriores do rato e interrompida quando o animal apresenta a reação de "retirada" do membro. Neste modelo, o limiar de dor é representado como a força (g) necessária para a indução da reação. Este teste foi aplicado antes (medida inicial) e diversos tempos após a administração de $\mathrm{PGE}_{2}$, na pata e de crotalfina pela via oral ou intraplantar. Os resultados foram analisados por meio 
da comparação das médias das medidas iniciais e finais ou, quando determinado, através da comparação das médias obtidas nos diferentes grupos experimentais.

\section{Figura 4 - Teste de pressão de pata de ratos}

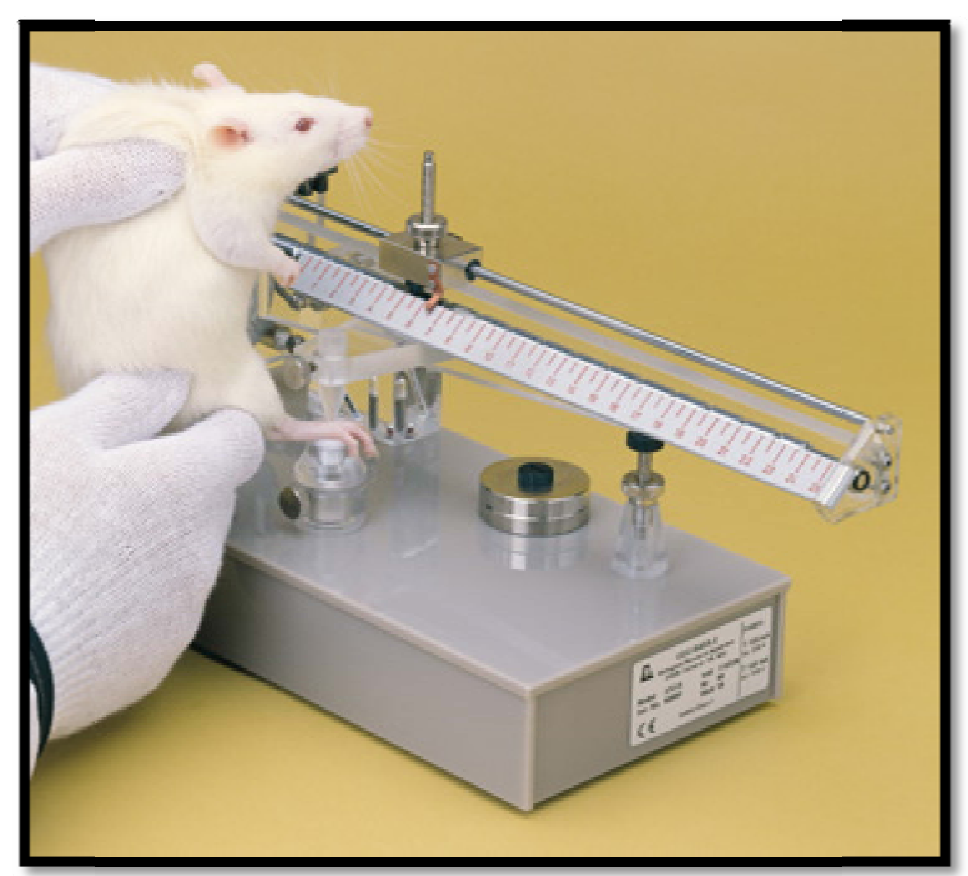

Fonte: Ugo Basile, Comerio, VA, Itália (2009)

\subsection{Tratamentos Farmacológicos}

Para avaliação do efeito analgésico, foi utilizada:

- Crotalfina (American Peptide Co, Sunnyvale, CA, Estados Unidos), administrada por via p.o., 2 horas após da $\mathrm{PGE}_{2}$, nas doses de 0,008; 0,016; 0,$04 ; 0,2 ; 1 \mu \mathrm{g} / \mathrm{kg}$, ou por via intraplantar na dose de $0,0006 \mu \mathrm{g} / \mathrm{pata}$.

Para avaliar a participação de receptores canabinóides no efeito antinociceptivo da crotalfina, foram utilizados:

- AM251 (Tocris Bioscience, Bristol, BS11 0QL, Reino Unido), antagonista com seletividade aproximadamente 360 vezes maior para receptores $\mathrm{CB}_{1}$ do que para $\mathrm{CB}_{2}$ (GATLEY et al., 1997; LAN et al., 1999), injetado por via i.pl. (80 e $120 \mu \mathrm{g} /$ pata).

- AM630 (Tocris Bioscience, Bristol, BS11 0QL, Reino Unido), antagonista com seletividade entre 70 a 165 vezes maior para receptores $\mathrm{CB}_{2}$ do que para 
CB 1 (HOSOHATA et al., 1997; ROSS et al., 1999), injetado por via i.pl. (10; 25 e $50 \mu \mathrm{g} /$ pata).

Para a determinação das doses de antagonistas de receptores canabinóides que apresentassem apenas efeito local, foi inicialmente determinada uma curva dose-resposta do respectivo agonista, a fim de se encontrar a dose capaz de acarretar analgesia periférica de mesma intensidade de crotalfina. A partir da determinação da dose do agonista, procuramos a dose de antagonista capaz de reverter a antinocicepção local causada pelo respectivo agonista. Encontrada esta dose, esta foi avaliada sobre o efeito da crotalfina. Assim, como agonistas canabinóides, foram utilizados:

- AM1241 (Cayman Chemical, Ann Arbor, MI, Estados Unidos), agonista com seletividade 340 vezes maior para receptores $\mathrm{CB}_{2}$ do que para $\mathrm{CB}_{1}$ (GOUTOPOULOS; MAKRIYANNIS, 2002; IBRAHIM et al., 2003), injetado por via i.pl. nas doses de 0,$5 ; 1 ; 5 ; 10 ; 20 ; 50 \mu \mathrm{g} /$ pata

- ACEA (Tocris Bioscience, Bristol, BS11 0QL, Reino Unido), agonista com seletividade 1400 vezes maior para receptores $\mathrm{CB}_{1}$ do que para $\mathrm{CB}_{2}$ (HILLARD et al., 1999), injetado por via i.pl. nas doses de 1; 5; 10; 20; 25 e $50 \mu \mathrm{g} / \mathrm{pata}$

Para avaliar se a ação da crotalfina em receptores $\mathrm{CB}_{1}$ e $\mathrm{CB}_{2}$ ocorre direta ou indiretamente, pela liberação de endocanabinóides, utilizamos o Orlistat, um inibidor do diacilglicerol (precursor dos endocanabinóides, produzido a partir da hidrólise de fosfoinositídeos de membrana), a fim de se verificar se este inibidor é capaz de interferir com a antinocicepção induzida pela crotalfina, ou o MAFP (metil araquidonil fluorofosfonado), um inibidor da hidrolase amida de ácidos graxos (enzima que hidrolisa os endocanabinóides), a fim de se verificar se este inibidor é capaz de potencializar a antinocicepção induzida pela crotalfina. Assim, utilizamos:

- Orlistat (Tocris Bioscience, Bristol, BS11 0QL, Reino Unido), injetado por via i.pl., 4 e $12 \mu \mathrm{g} /$ pata.

- MAFP (Tocris Bioscience, Bristol, BS11 0QL, Reino Unido), injetado por via i.pl., $4 \mu \mathrm{g} /$ pata.

Para se avaliar se a ativação dos receptores canabinóides acarreta liberação de opióides endógenos foram utilizados anticorpos anti-opióides endógenos, administrados por via intraplantar. Os seguintes anticorpos foram utilizados: 
- Anticorpo anti- Met-Encefalina (Bachem, San Carlos, CA, Estados Unidos) injetado por via i.pl., 0,$1 ; 1 ; 10$ e $50 \mu \mathrm{g} /$ pata.

- Anticorpo anti- $\beta$-endorfina (Bachem, San Carlos, CA, Estados Unidos) injetada por via i.pl., 0,$05 ; 0,5$ e $5 \mu \mathrm{g} /$ pata.

- Anticorpo anti- Dinorfina-A (Bachem, San Carlos, CA, Estados Unidos) injetado por via i.pl., 0,01; 0,1 e $1 \mu \mathrm{g} /$ pata.

- Captopril, inibidor da enzima peptidil dipeptidase A (Sigma, St. Louis, MO, Estados Unidos), capaz de degradar opióides endógenos, injetado por via i.pl., $10 \mu \mathrm{g} / \mathrm{pata}$ e gentilmente cedido pelo Prof. Dr. Benedito Carlos Prezoto do Departamento de Farmacologia do Intituto Butantan.

\subsection{Determinação da atividade de receptores canabinóides e opióides: Imunomarcação em slice (fatia)}

Com o objetivo de investigar se a crotalfina é capaz de acarretar ativação dos receptores canabinóides ou opióides, investigamos as alterações conformacionais destes receptores pelo método de imunomarcação em slice (fatia), na pata dos animais tratados com este analgésico. Para tanto, ratos tratados com $\mathrm{PGE}_{2}$ na pata e crotalfina ou salina (controle) por via oral ou intraplantar tiveram o tecido plantar removido e imediatamente congelados à $80{ }^{\circ} \mathrm{C}$. O tecido foi emblocado em "tissue freezing medium” (TBS $®$ ). Posteriormente, foram realizados cortes de $10 \mu \mathrm{m}$ em criostato. Os cortes foram colocados em lâmina e bloqueados com $1 \%$ de BSA $+5 \%$ de sacarose. A técnica de imunomarcação foi empregada nestes tecidos. O material foi incubado overnight com anticorpos conformação especifica anti-CB $\mathrm{CB}_{1}$, $\mathrm{CB}_{2}$, mu, kappa e delta, na diluição de 1:1000 (Proteimax Biotecnologia Ltda, Cotia, SP, Brasil) marcados com fluorescência (Alexa Flúor $680 \mathrm{~nm}$ ou $800 \mathrm{~nm}$ ). Estes anticorpos são sensíveis a alteração conformacional mediada por ativação do receptor, podendo então reconhecer diferentes estados de ativação deste receptor (GUPTA et al., 2007). Após este período as lâminas foram lavadas 3 vezes em PBS e a análise de quantificação de fluorescência foi realizada em leitor de fluorescência utilizando o equipamento Odyssey (LiCOR) (GUPTA et al., 2007). O aumento da ativação dos receptores foi avaliado levando em consideração o número total de receptores expressos no mesmo tecido. 


\subsection{Avaliação da possível liberação local de opióides endógenos, por células do tecido plantar de ratos, induzida pela crotalfina}

Para se avaliar se a liberação de opióides endógenos poderia ocorrer localmente, pelo tecido dérmico da pata, foi utilizado o método segundo Ibrahim et al (IBRAHIM et al., 2005). Após 2 horas do tratamento com 100 ng de $\mathrm{PGE}_{2}$ via intraplantar, animais sensibilizados foram eutanaziados utilizando-se isofluorano $4 \%$, e o tecido plantar foi removido. Um cortador de $4 \mathrm{~mm}$ de diâmetro foi utilizado para se obter tecidos plantares de mesmo tamanho. O tecido plantar foi então colocado em tubos de polipropileno, contendo solução de Hanks (HBSS; $1.26 \mathrm{mM} \mathrm{CaCl} 2 ; 5,33 \mathrm{mM} \mathrm{KCl} ; 0,44 \mathrm{mM} \mathrm{K \textrm {K } _ { 2 }} \mathrm{PO}_{4} ; 0,5 \mathrm{mM} \mathrm{MgCl} ; 0,41 \mathrm{mM}$ $\mathrm{MgSO}_{4} ; 138 \mathrm{mM} \mathrm{NaCl} ; 4 \mathrm{mM} \mathrm{NaHCO}{ }_{3} ; 0,3 \mathrm{mM} \mathrm{Na} \mathrm{HPO}_{4} ; 5,6 \mathrm{mM}$ glucose, pH 7.4), contendo $1 \%$ de BSA por 30 minutos a $37^{\circ} \mathrm{C}$. Crotalfina, nas concentrações de $2.6 \mathrm{nM}$ (que corresponde a dose de $0,0006 \mu \mathrm{g} /$ pata que induz efeito antinociceptivo periférico) e $1 \mu \mathrm{M}$ (concentração conhecida do peptídeo que ativa in vitro a cascata de sinalização intracelular relacionada às MAPkinases - dados não publicados), foi adicionada a este tubo, na presença ou não de antagonista de receptores $\mathrm{CB}_{2}$, e mantida por 30 minutos a $37^{\circ} \mathrm{C}$, em agitação para manter a oxigenação do tecido. O sobrenadante foi então coletado e mantido em gelo. A dosagem de $\beta$-endorfina, dinorfina-A e met-encefalina foi realizada utilizando-se kit imunoenzimático comercial - ELISA (Bachem, San Carlos, CA, Estados Unidos).

\subsection{Ensaio de ligação específica para receptores canabinóides}

O ensaio de ligação específica para os receptores canabinóides foi conduzido conforme previamente descrito por (CHIANESE et al., 2011; LIGRESTI et al., 2012). Membranas de receptores $\mathrm{CB}_{1}$ e $\mathrm{CB}_{2}$ humanos foram suspensas em tampão de incubação (50 $\mathrm{mM}$ de Tris- $\mathrm{HCl} \mathrm{pH}$ 7,2; $2,5 \mathrm{mM}$ de EDTA; $5 \mathrm{mM}$ de $\mathrm{MgCl}_{2}$ e $10 \%$ de soro fetal bovino). No mesmo tampão, foram diluídos o agonista canabinóide WIN 55212-2 (controle positivo, com concentração de incubação final de $10 \mu \mathrm{M}$ ) ou a crotalfina (concentração de incubação final 50; 25; 10; 5; 1;0,1;0,01;0,001;0,0001 e 0,00001 $\mu \mathrm{M})$. Membranas de células HEK-293 transfectadas com o receptor $\mathrm{CB}_{1}$ humano recombinante $(\mathrm{Bmax}=2,5 \mathrm{pmol}$ de proteína/mg) e do receptor $\mathrm{CB}_{2}$ humano recombinante $(\mathrm{Bmax}=4,7$ proteína $\mathrm{pmol} / \mathrm{mg})$ foram incubadas com o ligante de afinidade elevada radiomarcada ${ }^{[3 \mathrm{H}]} \mathrm{CP}-55940(0,14 \mathrm{nM}, \mathrm{Kd}=0,18 \mathrm{nM}$ e 0,084 $\mathrm{nM}, \mathrm{Kd}=0,31 \mathrm{nM}$, para os receptores $\mathrm{CB}_{1}$ e $\mathrm{CB}_{2}$, respectivamente) e deslocado com $10 \mu \mathrm{M}$ 
WIN 55212-2 (Ki valores de 9,2 $\mathrm{nM}$ e 2,1 $\mathrm{nM}$ para os receptores $\mathrm{CB}_{1}$ e $\mathrm{CB}_{2}$, respectivamente) ou com diferentes concentrações de crotalfina para a ligação não especifica. Todos os compostos foram ensaiados segundo o procedimento descrito pelo fabricante (PerkinElmer, Waltham, MA, Estados Unidos). As curvas de deslocamento foram geradas por incubação de drogas com ${ }^{[3 \mathrm{H}]} \mathrm{CP}-55$, 940. Para tanto, componentes do ensaio foram adicionados em tubos identificados, seguindo sempre a mesma ordem de incubação, conforme a tabela abaixo. Adicionados todos os componentes, todos os tubos foram incubados por 90 minutos a $30{ }^{\circ} \mathrm{C}$, em banho úmido.

Tabela 1 - Seqüência de incubação para realização do ensaio de ligação específica para receptores canabinóides

\begin{tabular}{|c|c|c|c|c|}
\hline & $\begin{array}{c}1 \\
\text { Tampão }\end{array}$ & $\begin{array}{c}2 \\
\text { Proteína } \\
\text { de } \\
\text { membrana } \\
\left(C B_{1} \text { ou }\right. \\
\left.C B_{2}\right)\end{array}$ & $\begin{array}{c}3 \\
{ }^{[3 \mathrm{H}]} \mathrm{CP55,490}\end{array}$ & $\begin{array}{c}4 \\
\text { Fármaco }\end{array}$ \\
\hline Branco & $100 \mu \mathrm{l}$ & - & $100 \mu \mathrm{l}$ & - \\
\hline Controle & $50 \mu \mathrm{l}$ & $50 \mu \mathrm{l}$ & $100 \mu \mathrm{l}$ & - \\
\hline Controle Positivo & - & $50 \mu \mathrm{l}$ & $100 \mu \mathrm{l}$ & $50 \mu \mathrm{l}$ de WIN55212-2 \\
\hline Amostra desconhecida & - & $50 \mu \mathrm{l}$ & $100 \mu \mathrm{l}$ & $50 \mu \mathrm{l}$ de crotalfina \\
\hline
\end{tabular}

Nota: Tampão: veículo utilizado para diluição

Proteína de membrana:

${ }^{[3 \mathrm{H}]} \mathrm{CP55,490:}$ Membranas de células HEK-293 transfectadas com o receptor $\mathrm{CB}_{1}$ humano recombinante $\left(B \max =2,5\right.$ pmol de proteína/mg) e do receptor $\mathrm{CB}_{2}$ humano recombinante $(\mathrm{Bmax}=4,7$ proteína $\mathrm{pmol} / \mathrm{mg}$ )

Fármaco: ligante de deslocamento; $10 \mu \mathrm{M}$ de WIN 55212-2 (controle de ligação máxima do dia, Ki valores de $9,2 \mathrm{nM}$ e $2,1 \mathrm{nM}$ para os receptores $\mathrm{CB}_{1}$ e $\mathrm{CB}_{2}$, respectivamente) ou $50 ; 25 ; 10 ; 5 ; 1 ; 0,1$; 0,$01 ; 0,001 ; 0,0001$ e $0,00001 \mu \mathrm{M}$ de crotalfina (fármaco teste)

A reação foi interrompida por filtração. Os filtros foram previamente tratados com solução de polietilenoimina $(0,1 \%)$ por um período mínimo de 2 h. Em seguida os filtros foram expostos à filtração a vácuo da solução teste e então lavados com o tampão de incubação. As amostras foram filtradas e, imediatamente após a filtração, os filtros foram então transferidos para frascos específicos para detecção de radioatividade. Nestes frascos, foi adicionado, ainda, um detergente específico para a propagação do sinal radioativo. Após 1 hora, a leitura da radioatividade foi realizada. A porcentagem de ligação da crotalfina nos 
receptores $\mathrm{CB}_{1}$ e $\mathrm{CB}_{2}$ foi calculada considerando a porcentagem de deslocamento máximo do radioligante canabinoide marcado ${ }^{[3 \mathrm{H}]} \mathrm{CP}-55940$ induzido pelo controle positivo, WIN 552122, valor de referência para portentagem de ligação máxima (100\%) obtida no dia do experimento. Os dados são médias de quatro experiências independentes.

A constante de inibição $(\mathrm{K} i)$ dos compostos competidores foi calculada usando a equação de Cheng-Prusoff (CHENG; PRUSOFF, 1973).

$$
K_{i}=\frac{I C_{50}}{\frac{[A]}{E C_{50}}+1}
$$

Já os valores de $\mathrm{IC}_{50}$ foram obtidos por programa GraphPad Prism versão 4.0 para Windows (GraphPad Software, San Diego, CA, Estados Unidos) para o deslocamento do radioligante ligado por concentrações crescentes do composto de ensaio.

\subsection{Análise estatística}

A análise estatística foi realizada por meio de variância (SNEDECOR, 1946) associada ao teste de Tukey (SNEDECOR et al., 1946), para comparação de mais de duas médias. $\mathrm{O}$ índice de significância foi de $\mathrm{p}<0,05$. 


\section{RESULTADOS}

\subsection{Padronização da hiperalgesia induzida por $\mathrm{PGE}_{2}$}

Inicialmente foi avaliado o efeito nociceptivo da prostaglandina $\mathrm{E}_{2}\left(\mathrm{PGE}_{2}\right)$ sobre o limiar de resposta dos ratos ao estímulo mecânico (teste de pressão de pata).

A administração intraplantar de $100 \mathrm{ng}$ de prostaglandina $\mathrm{E}_{2}$ induziu alterações significativas no limiar de resposta dos animais somente na terceira hora do tempo de observação.

Figura 5 - Curva tempo-resposta do efeito nociceptivo da $\mathrm{PGE}_{2}$

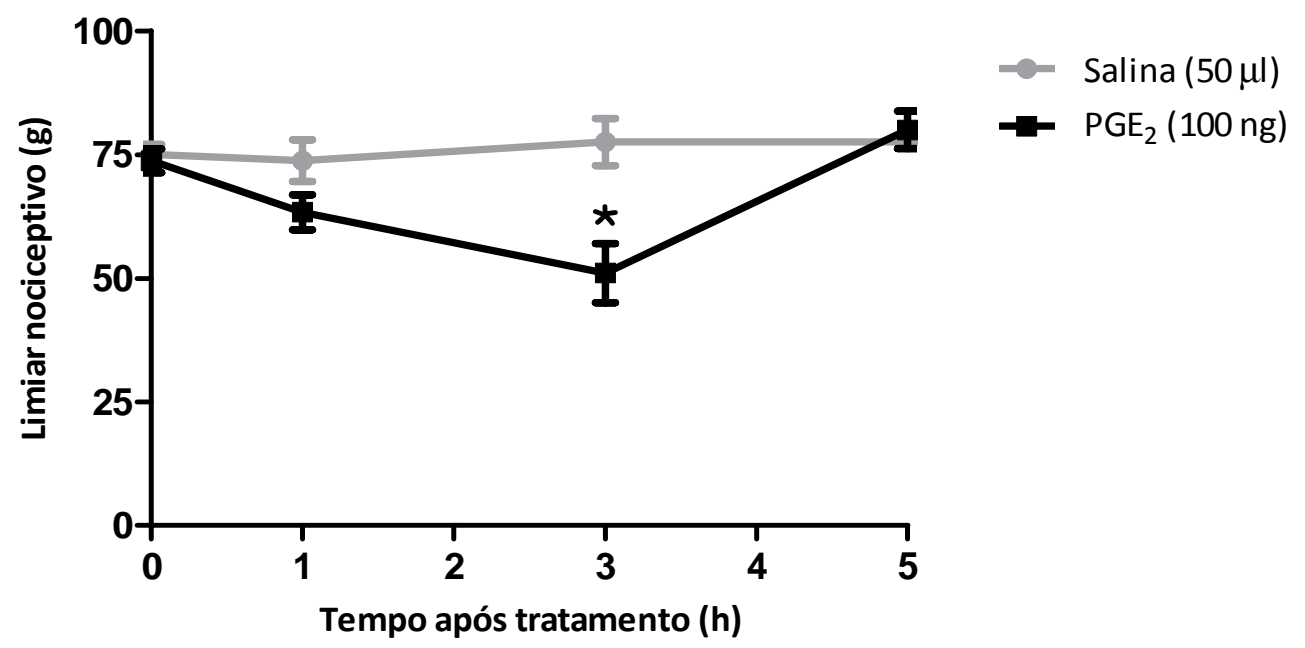

O limiar nociceptivo está representado pela força (em gramas) necessária para o rato apresentar a reação de "retirada" da pata. As medidas foram realizadas antes (tempo 0), 1, 3 e 5 horas após a administração intraplantar de $100 \mathrm{ng}$ de prostaglandina $\mathrm{E}_{2}$. O grupo controle foi composto por animais injetados com solução salina estéril. Os dados representam a média \pm e.p.m. de pelo menos 5 animais por grupo. ${ }^{*}$ p $<0,05$ por comparação com a medida basal. 


\subsection{Efeito sistêmico e local da crotalfina sobre a hiperalgesia induzida por PGE $_{2}$}

Foram testadas cinco doses da crotalfina, por via oral, e uma dose local, via intraplantar. A escolha das doses foi baseada em dados experimentais anteriores obtidos por nosso grupo, mostrando sua efetividade em inibir a sensibilidade dolorosa dos animais em diversos modelos experimentais (GIORGI, 1996; GUTIERREZ, 2005; GUTIERREZ et al., 2008; PICOLO et al., 2003; PICOLO; CURY, 2004; PICOLO et al., 1998; PICOLO et al., 2000).

Como mostrado na figura $6 \mathrm{~A}$, a dose de $0,008 \mu \mathrm{g} / \mathrm{kg}$ de crotalfina reverteu parcialmente a hiperalgesia induzida pela administração intraplantar de 100 ng de PGE $_{2}$. Por outro lado, a reversão total da sensibilidade dolorosa foi observada nas doses de $0,04 \mu \mathrm{g} / \mathrm{kg}$ e $0,2 \mu \mathrm{g} / \mathrm{kg}$ do analgésico. A administração pela via oral de $1 \mu \mathrm{g} / \mathrm{kg}$ do peptídeo sintético mostrou-se capaz não só de reverter totalmente a hipernocicepção, como também de aumentar o limiar basal de resposta nociceptiva do rato. Esta dose foi selecionada para os ensaios subseqüentes, uma vez que induziu aumento na resposta dos animais semelhante ao aumento induzido pela dose padrão de morfina ( $5 \mathrm{mg} / \mathrm{kg}$, s.c.), utilizada como controle positivo.

Com relação à administração local de crotalfina, a figura 6B demonstra que a dose de $0,0006 \mu \mathrm{g} /$ pata de crotalfina também se mostrou capaz não só de reverter totalmente a hipernocicepção, como também de aumentar o limiar basal de resposta nociceptiva do rato sem interferir com a hiperalgesia induzida pela $\mathrm{PGE}_{2}$ na pata contralateral, comprovando seu efeito apenas local, e sendo selecionada para os ensaios de atividade local subseqüentes. 
Figura 6 - Curva dose-resposta da crotalfina

A

Salina $\square$ Crotalfina ( $\mu \mathrm{g} / \mathrm{kg} ;$ p.o.) $\gg$ Morfina (mg/kg; s.c.)

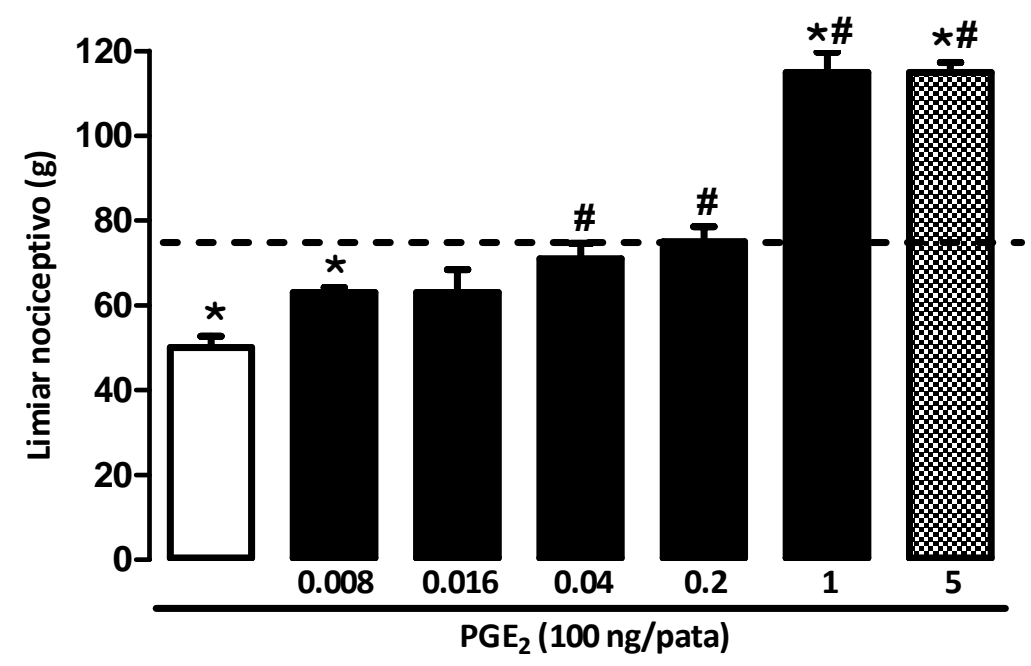

B

Salina Crotalfina $(0,0006 \mu \mathrm{g} /$ pata $)$

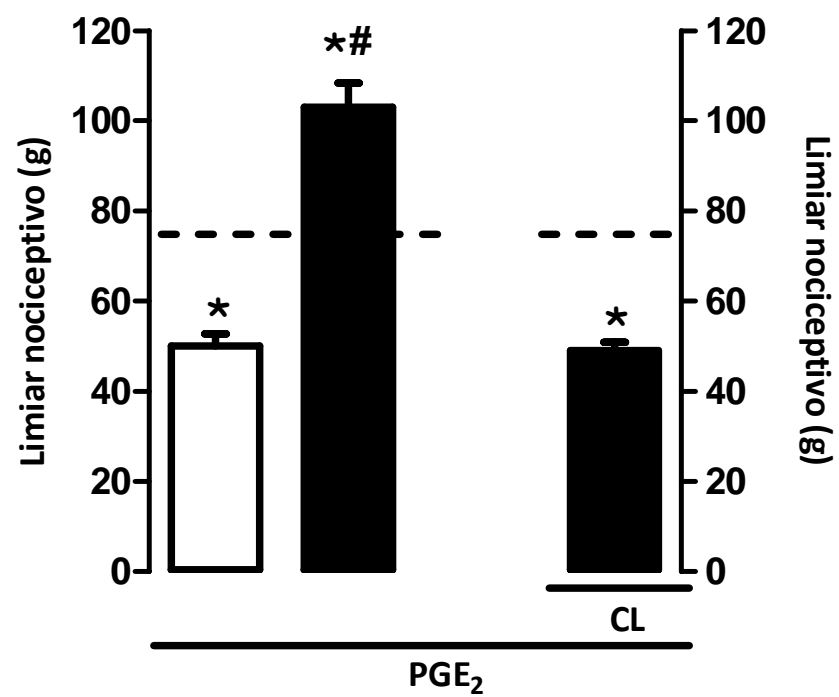

O limiar nociceptivo está representado pela força (em gramas) necessária para o animal apresentar a reação de "retirada" da pata. As medidas foram realizadas antes (medida inicial, representada pela linha tacejada) e 3 horas após a administração intraplantar de $100 \mathrm{ng}$ de $\mathrm{PGE}_{2}$ (medida final, pós-tratamento, representada pelas barras). Crotalfina foi administrada via oral (painel A) e via intraplantar (painel B) 2 horas depois da administração intraplantar de $\mathrm{PGE}_{2}$. $\mathrm{O}$ grupo controle foi composto por animais tratados com $\mathrm{PGE}_{2}$ (i.pl.) e administração de salina estéril (p.o., painel A ou i.pl., painel B). Os dados representam a média \pm e.p.m. de pelo menos 5 animais por grupo. *p<0,05 por comparação com a medida basal (tempo 0 ), \# por comparação com o grupo controle e \& por comparação com o grupo tratado com $1 \mu \mathrm{g} / \mathrm{kg}$ de crotalfina. 


\subsection{Avaliação da atividade de agonistas e antagonistas canabinóides $\mathrm{CB}_{1}$ e $\mathrm{CB}_{2}$}

Para a seleção das doses de antagonistas de receptores canabinóides foi inicialmente determinada uma curva dose-resposta dos agonistas canabinóides, a fim de se encontrar a dose capaz de acarretar analgesia periférica de mesma intensidade do peptídeo sintético. A partir da determinação da dose de cada agonista $\left(\mathrm{CB}_{1}\right.$ e $\left.\mathrm{CB}_{2}\right)$, procuramos a dose do respectivo antagonista capaz de reverter a antinocicepção local causada pelo agonista. As doses de antagonista $\mathrm{CB}_{1}$ e $\mathrm{CB}_{2}$ capazes de reverter o efeito periférico e local do seu respectivo agonista foram selecionadas e desafiadas sobre o efeito da crotalfina.

É importante ressaltar que a escolha das doses de todas as drogas, administradas por via intraplantar, esteve baseada em dados da literatura, mostrando sua efetividade em inibir a sensibilidade dolorosa dos animais em diversos modelos experimentais (ANAND et al., 2009; BURGOS et al., 2009; GOUTOPOULOS; MAKRIYANNIS, 2002; GUERRERO et al., 2008; GUTIERREZ et al., 2007; HILLARD et al., 1999; IBRAHIM et al., 2003; MALAN et al., 2001)

4.5.1 Curva dose-resposta do ACEA, agonista de receptor $\mathrm{CB}_{1}$

Inicialmente, foram testadas quatro doses do ACEA, agonista de receptor canabinóide do tipo 1. O ACEA apresentou atividade antinociceptiva dose-dependente, em ratos, sobre a hiperalgesia induzida por $\mathrm{PGE}_{2}$. As doses de 10, 20 e $50 \mu \mathrm{g} /$ pata mostraram-se capazes de reverter completamente a hiperalgesia induzida por $100 \mathrm{ng}$ de $\mathrm{PGE}_{2}$. No entanto, somente a dose de $50 \mu \mathrm{g} / \mathrm{pata}$ induziu um aumento no limiar basal de resposta nociceptiva dos ratos, representado na figura $10 \mathrm{~A}$ pela linha tracejada, efeito antinociceptivo este de mesma intensidade quando comparada com $1 \mu \mathrm{g} / \mathrm{kg}$ de crotalfina (p.o.) e $5 \mathrm{mg} / \mathrm{kg}$ de morfina (s.c.). 
Figura 7 - Curva dose-resposta do agonista de receptor $\mathrm{CB}_{1}$

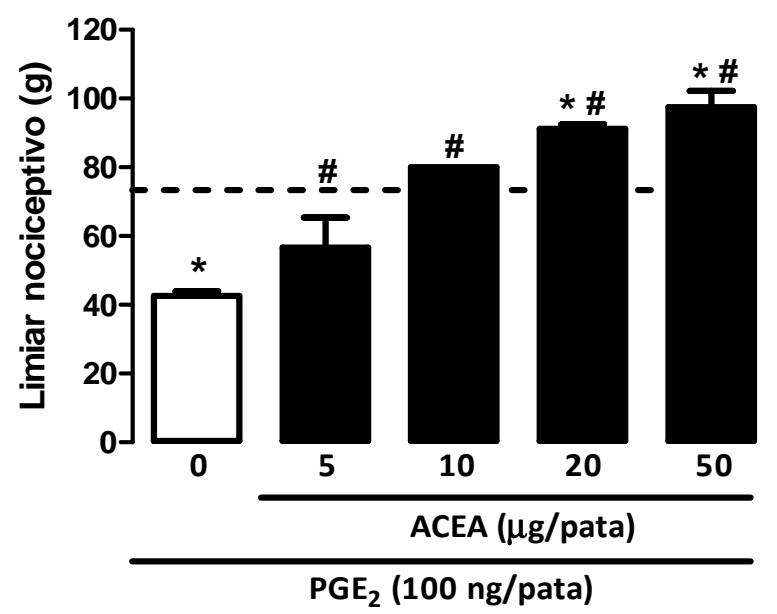

No painel A, o limiar nociceptivo está representado pela força (em gramas) necessária para o animal apresentar a reação de "retirada" da pata. ACEA foi administrado via intraplantar 2 horas depois da injeção do agente hiperalgésico (i.pl.). O grupo controle foi composto por animais tratados com injeção intraplantar de $\mathrm{PGE}_{2} \mathrm{e}$ veículo (i.pl., DMSO 6\% em água destilada). Os dados representam a média \pm e.p.m. de pelo menos 5 animais por grupo. * $\mathrm{p}<0,05$ por comparação com a medida basal e \# por comparação com o grupo controle.

4.5.2 Curva dose-resposta do AM1241, agonista de receptor $\mathrm{CB}_{2}$

Foram testadas quatro doses do AM1241, agonista de receptor canabinóide do tipo 2. Como representada na figura 11A, todas as doses de AM1241 testadas apresentaram atividade antinociceptiva de mesma intensidade. As doses de 5, 10, 20 e $50 \mu \mathrm{g} /$ pata mostraram-se capazes de reverter totalmente a hiperalgesia induzida por $100 \mathrm{ng}$ de $\mathrm{PGE}_{2}$. Entretanto, nenhuma dessas doses apresentou capacidade de aumentar o limiar de resposta nociceptiva basal dos ratos. Portanto, a dose de $5 \mu \mathrm{g} /$ pata foi selecionada para ensaios subseqüentes, uma vez que não houve diferença no efeito antinociceptivo observado pelas diferentes doses. 


\section{Figura 8 - Curva dose-resposta do agonista de receptor $\mathbf{C B}_{2}$}

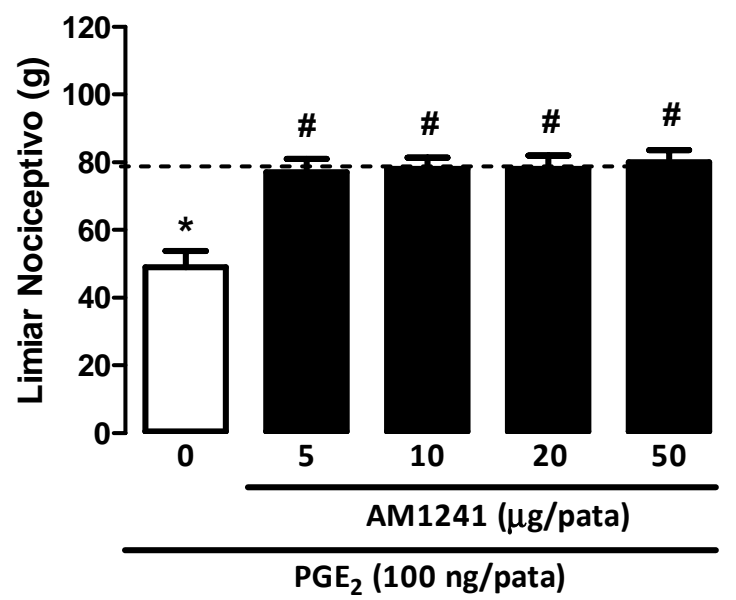

No painel A, o limiar nociceptivo está representado pela força (em gramas) necessária para o animal apresentar a reação de "retirada" da pata. As medidas foram realizadas antes (medida inicial, pré-tratamento, representada pela linha tracejada somente no painel A) e 3 horas após a administração intraplantar do agente hiperalgésico (100 ng de $\mathrm{PGE}_{2}$ : medida final, pós-tratamento, representada pelas barras). AM1241 foi administrado via intraplantar 2 horas depois da injeção do agente hiperalgésico (i.pl.). O grupo controle foi composto por animais tratados com injeção intraplantar de $\mathrm{PGE}_{2}$ e veículo (i.pl., DMSO 6\% em água destilada). Os dados representam a média \pm e.p.m. de pelo menos 5 animais por grupo. ${ }^{*} \mathrm{p}<0,05$ por comparação com a medida basal e \# por comparação com o grupo controle.

\subsubsection{Avaliação do AM251 sobre o efeito antinociceptivo do ACEA}

Para este ensaio, a dose de $50 \mu \mathrm{g} /$ pata (i.pl.) do agonista de receptor canabinóide do tipo 1, ACEA, foi selecionada no ensaio anterior. A escolha da dose do antagonista AM251, $80 \mu \mathrm{g}$ administrada por via intraplantar, esteve baseada em dados da literatura, mostrando sua efetividade em reverter o efeito inibitório do ACEA sobre a sensibilidade dolorosa local dos animais em diversos modelos experimentais (GATLEY et al., 1997; LAN et al., 1999).

Como demonstrada na figura 9, a dose de $50 \mu \mathrm{g} /$ pata de agonista $\mathrm{CB}_{1}$ acarreta efeito antinociceptivo periférico local, uma vez que a antinocicepção foi observada apenas na pata injetada, sem induzir alterações significativas na hiperalgesia induzida por $\mathrm{PGE}_{2}$ na pata contralateral. O AM251 reverteu totalmente a atividade antinociceptiva do seu respectivo agonista, ACEA, sem induzir, per se, alterações significativas no limiar nociceptivo dos ratos.

Portanto, a dose de $80 \mu \mathrm{g}$ de AM630 (i.pl.) foi selecionada para ensaios subsequientes a fim de verificar a participação de receptores $\mathrm{CB}_{1}$ periféricos no efeito da crotalfina. 
Figura 9 - AM251 foi capaz de reverter o efeito local induzido pelo ACEA

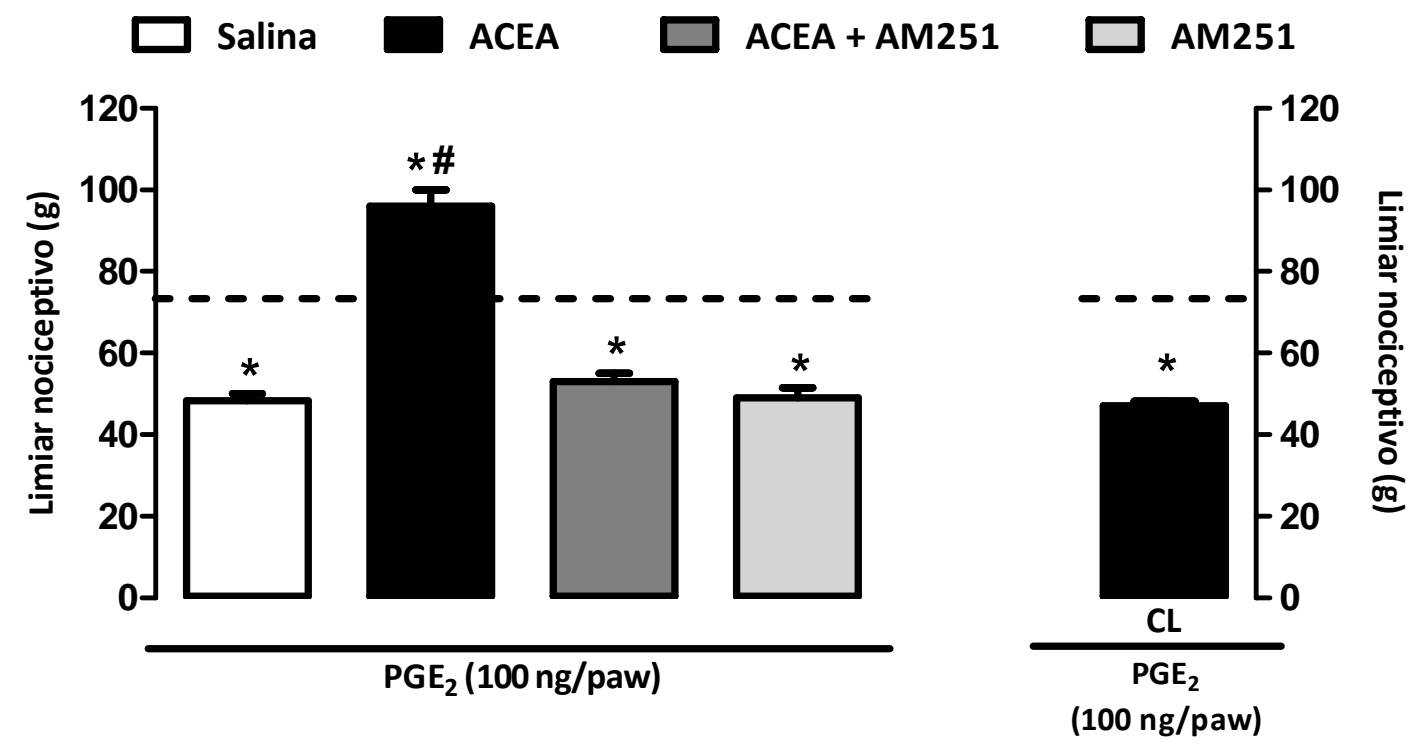

O limiar nociceptivo está representado pela força (em gramas) necessária para o animal apresentar a reação de "retirada" da pata. As medidas foram realizadas antes (medida inicial, pré-tratamento, representada pela linha tracejada) e 3 horas após a administração intraplantar do agente hiperalgésico (100 ng de PGE 2 : medida final, pós-tratamento, representada pelas barras). AM251 (80 $\mu \mathrm{g} / \mathrm{pata})$ foi administrado via intraplantar 30 minutos antes do ACEA (50 $\mu \mathrm{g} /$ pata) e 2 horas depois da injeção do agente hiperalgésico (i.pl.). O grupo controle foi composto por animais tratados com $\mathrm{PGE}_{2}$ (i.pl.) e veículo (i.pl., DMSO 6\% em água destilada). Os dados representam a média \pm e.p.m. de pelo menos 5 animais por grupo. $*$ p $<0,05$ por comparação com a medida basal e \# por comparação com o grupo controle.

\subsubsection{Avaliação do AM630 sobre o efeito antinociceptivo do AM1241}

Devido ao fato de não haver diferença na intensidade de nocicepção entre todas as diferentes doses testadas do agonista de receptor canabinóide do tipo 2, AM1241, a menor dose, $5 \mu \mathrm{g} /$ pata, foi escolhida para avaliar a atividade do seu respectivo antagonista, AM630.

A escolha da dose do AM630, $50 \mu \mathrm{g}$ administrada por via intraplantar, esteve baseada em dados da literatura, mostrando sua efetividade em reverter o efeito inibitório do AM1241 sobre a sensibilidade dolorosa dos animais em diversos modelos experimentais (HOSOHATA et al., 1997; ROSS et al., 1999).

Como demonstrada na figura 10 , a dose de $5 \mu \mathrm{g} /$ pata de agonista $\mathrm{CB}_{2}$ tem efeito periférico local, uma vez que não induziu alterações significativas na hiperalgesia induzida por injeção intraplantar de $\mathrm{PGE}_{2}$ na pata contralateral. O antagonista AM630 reverteu totalmente a atividade antinociceptiva do seu respectivo agonista, sem interferir, per se, com o limiar nociceptivo dos ratos.

Portanto, a dose de $50 \mu \mathrm{g}$ de AM630 (i.pl.) foi selecionada para ensaios subseqüentes a fim de verificar a participação de receptores $\mathrm{CB}_{2}$ no efeito da crotalfina. 
Figura 10 - AM630 foi capaz de inibir o efeito local do AM1241

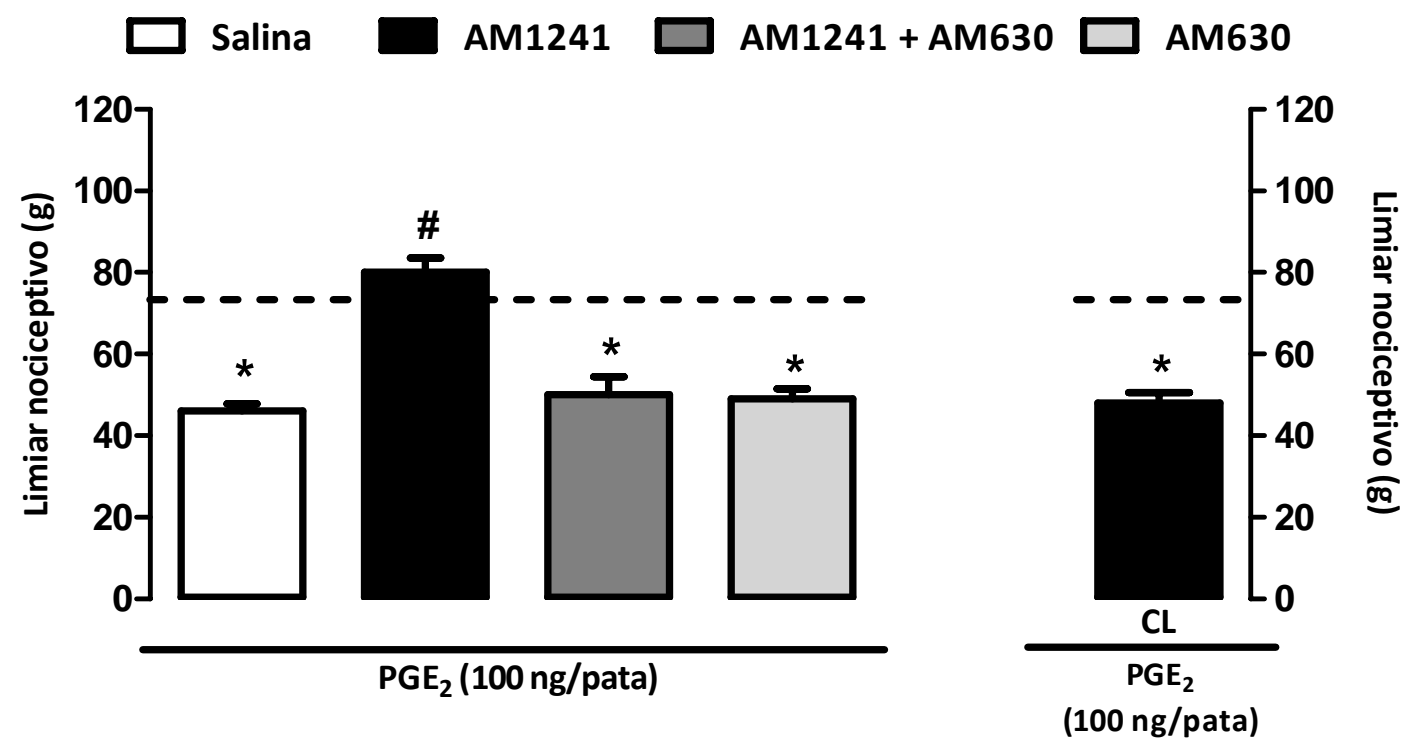

O limiar nociceptivo está representado pela força (em gramas) necessária para o animal apresentar a reação de "retirada" da pata. As medidas foram realizadas antes (medida inicial, pré-tratamento, representada pela linha tracejada) e 3 horas após a administração intraplantar do agente hiperalgésico (100 ng de PGE 2 : medida final, pós-tratamento, representada pelas barras). AM630 (50 $\mu \mathrm{g} /$ pata) foi administrado via intraplantar 30 minutos antes do AM1241 (5 $\mu \mathrm{g} /$ pata) e 2 horas depois da injeção do agente hiperalgésico (i.pl.). O grupo controle foi composto por animais tratados com $\mathrm{PGE}_{2}$ (i.pl.) e veículo (i.pl., DMSO 6\% em água destilada). Os dados representam a média \pm e.p.m. de pelo menos 5 animais por grupo. $*$ p $<0,05$ por comparação com a medida basal e \# por comparação com o grupo controle.

\subsection{Avaliação da participação do sistema canabinóide no efeito da crotalfina}

A injeção intraplantar de AM251, antagonista de receptores canabinóides do tipo 1, reverteu parcialmente o efeito antinociceptivo induzido pela crotalfina adminstrada por via oral (Fig. 11A), enquanto que o AM630, antagonista de receptores canabinóides do tipo 2, administrado pela mesma via, mostrou-se capaz de reverter completamente a antinocicepção da crotalfina adminstrada por via oral (Fig. 11B) e intraplantar (Fig. 11C), na vigência de hiperalgesia aguda induzida por $\mathrm{PGE}_{2}$. Uma vez que a reversão pelo antagonista $\mathrm{CB}_{1}$ foi parcial, uma dose maior foi testada $(120 \mu \mathrm{g} /$ pata). Porém, os mesmos resultados foram obtidos, confirmando essa reversão parcial do efeito da crotalfina. Os antagonistas, per se, não interferiram no limiar nociceptivo dos animais no modelo avaliado. 
Figura 11 - Atividade antinociceptiva da crotalfina é mediada por receptores canabinóides periféricos

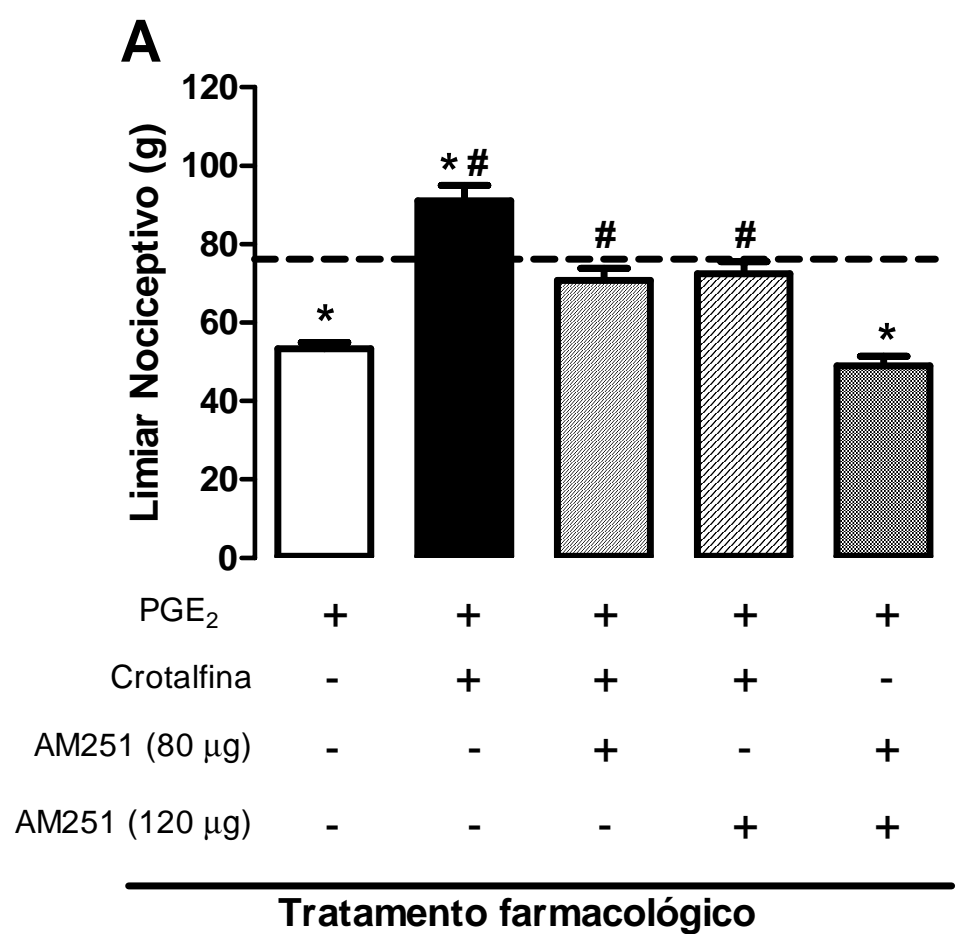

B

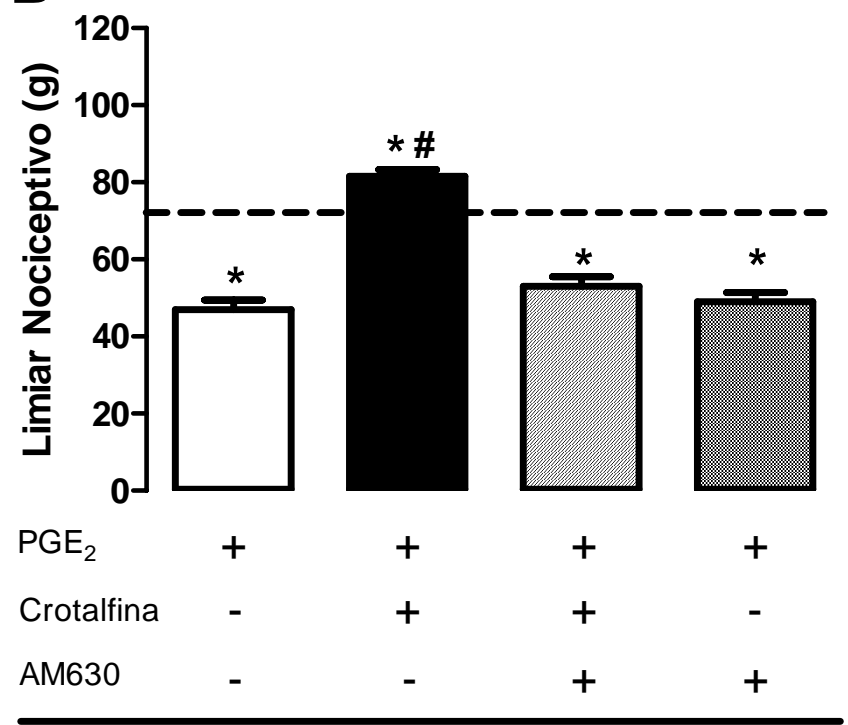

Tratamento farmacológico 
C
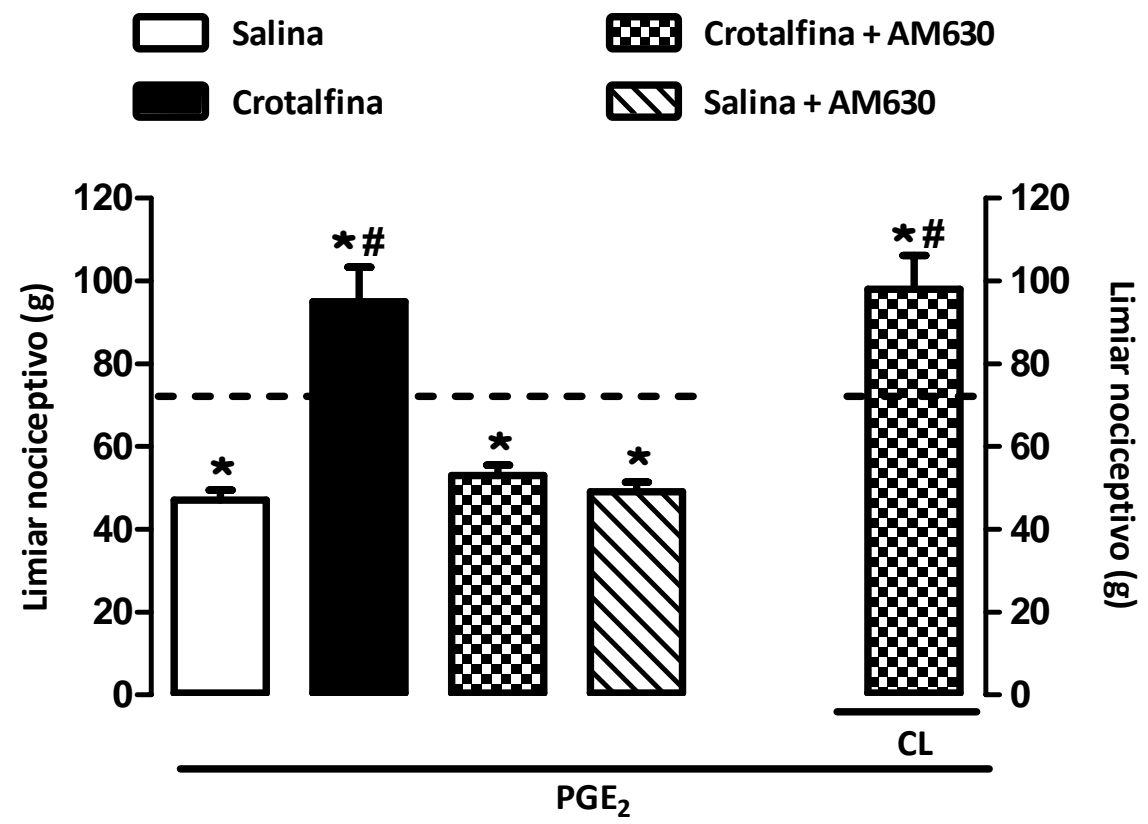

O limiar nociceptivo está representado pela força (em gramas) necessária para o animal apresentar a reação de "retirada" da pata. As medidas foram realizadas antes (medida inicial, representada pela linha tacejada) e 3 horas após a administração intraplantar de $100 \mathrm{ng}$ de $\mathrm{PGE}_{2}$ (medida final, pós-tratamento, representada pelas barras). AM251 (80 e $120 \mu \mathrm{g} /$ pata, painel A) e AM630 (50 $\mu \mathrm{g} /$ pata, painel B e C) foram administrados via intraplantar 30 minutos antes do crotalfina $(1 \mu \mathrm{g} / \mathrm{kg}$. p.o., painel $\mathbf{A}$ e $\mathbf{B} ; 0,0006 \mu \mathrm{g} / \mathrm{pata}$, i.pl., painel $\mathbf{C}-2$ horas após à injeção de $\mathrm{PGE}_{2}$ ). $\mathrm{O}$ grupo controle foi composto por animais tratados com $\mathrm{PGE}_{2}$ (i.pl.), salina estéril (p.o.) e veículo (i.pl., DMSO 6\% em água destilada). Os dados representam a média \pm e.p.m. de pelo menos 5 animais por grupo. ${ }^{*} \mathrm{p}<0,05$ por comparação com a medida basal e \# por comparação com o grupo controle. 


\subsection{Avaliação da ativação de receptores opióides e canabinóides após o tratamento local com crotalfina}

Uma vez que dados anteriores de nosso grupo indicavam a participação de receptores opióides kappa no efeito da crotalfina, e os dados obtidos presentemente demonstravam a participação de receptores $\mathrm{CB}_{2}$ neste efeito, investigamos qual receptor apresentava realmente aumento na sua atividade após o tratamento dos animais com crotalfina. Assim, investigamos a alteração no estado conformacional dos receptores canabinóides e opióides induzida pela crotalfina. Para tanto, foram realizados ensaios de imunomarcação em slice (fatia), no tecido da pata de ratos, utilizando anticorpos fluorescentes sensíveis à conformação específica do estado ativado de receptores $\mathrm{CB}_{1}, \mathrm{CB}_{2}, m u$, kappa e delta. Esses anticorpos são capazes de distinguir mudanças conformacionais destes receptores, já que são capazes de reconhecer a parte da porção N-terminal exposta somente quando o receptor se encontra no seu estado ativado (GUPTA et al., 2007) (Proteimax Biotecnologia, Cotia, SP, Brasil).

Após a ánalise das imagens, foi realizada a quantificação de receptores ativados, levando em consideração o número de receptores totais expressos após cada tratamento, normalizando, assim, os dados obtidos. O resultado final foi analisado comparando os dados obtidos de tecido plantar de animais tratados com os dados obtidos de amostras de animais naïve (limiar basal de ativação de cada receptor, considerado 100\%).

A figura 12 demonstra que a administração intraplantar de $0,0006 \mu \mathrm{g}$ de crotalfina induziu um aumento significativo no nível de ativação de receptores $\mathrm{CB}_{2}$ e kappa opióide no tecido plantar de ratos pré-tratados com $\mathrm{PGE}_{2}$, sem alterar o estado de ativação dos receptores $\mathrm{CB}_{1}$ e delta, confirmando a ativação de ambos receptores kappa e $\mathrm{CB}_{2}$ periféricos pela crotalfina. Com relação ao receptor $m u$, este teve sua ativação inibida pela administração da $\mathrm{PGE}_{2}$, sendo que esta inibição não foi alterada pela injeção de crotalfina. 
Figura 12 - Tratamento local com crotalfina induz aumento no nível de ativação de receptores kappa opióide e canabinóide do tipo $\mathbf{C B}_{2}$

A

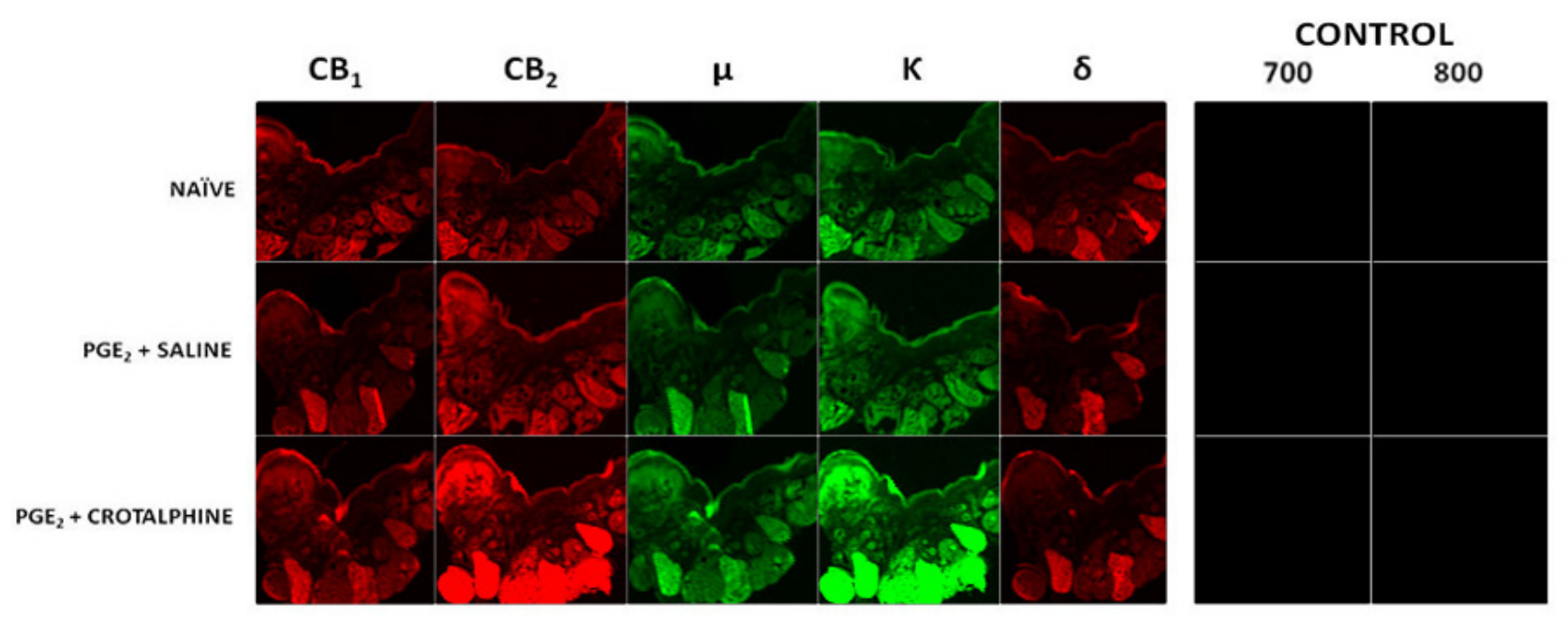

B

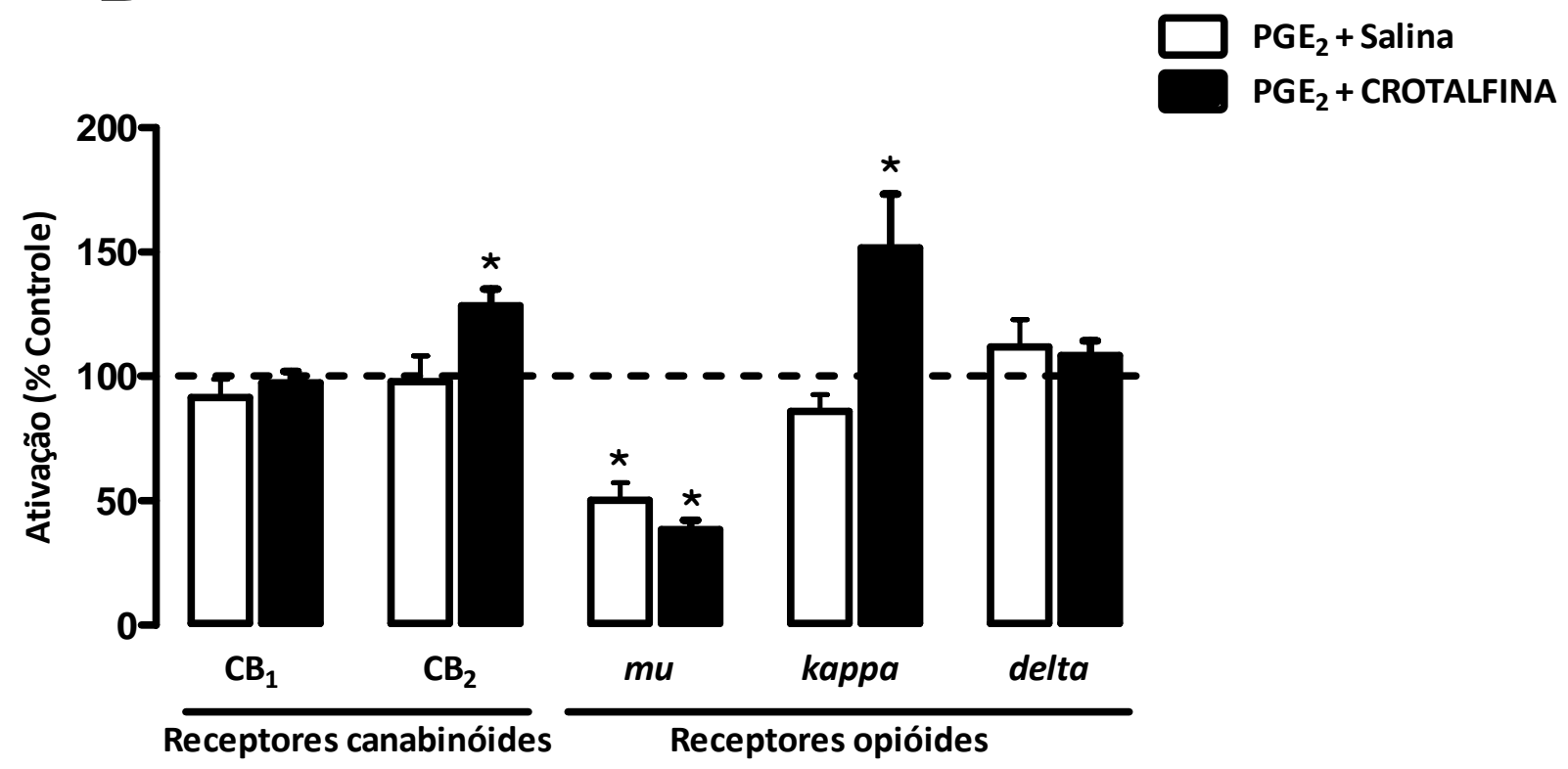

Ratos tratados com $\mathrm{PGE}_{2}(100 \mathrm{ng} / \mathrm{pata})$ e crotalfina $\left(0,0006 \mu \mathrm{g} / \mathrm{pata} ; 2\right.$ horas após a $\left.\mathrm{PGE}_{2}\right)$ foram eutanaziados (3 horas após o tratamento com a $\mathrm{PGE}_{2}$ ), perfundidos e tiveram o tecido plantar removido, seccionado e organizado em lâminas. Essas lâminas foram incubadas com anticorpos fluorescentes anti-receptores opióides (mu, kappa e delta) e canabinóides $\left(\mathrm{CB}_{1}\right.$ e $\mathrm{CB}_{2}$ ) ativados (diluição 1:4000), acarretando em dupla marcação na mesma lâmina. Essas lâminas foram submetidas a um sistema de detecção de imagem capaz de quantificar a fluorescência com alta precisão e sensibilidade, usando o sistema Odyssey (Li-COR). O painel A representa a análise qualitativa de receptores ativados nas imagens obtidas de fatias de uma amostra de tecido plantar de um mesmo animal de cada tratamento farmacológico; o painel B representa em forma de gráfico a análise quantitativa e normalizada de receptores ativados, sendo assim o aumento da ativação dos receptores avaliado levando em consideração o número total de receptores expressos no mesmo tecido.Os dados representam a média \pm e.p.m. de pelo menos 5 animais por grupo. * p $<0,05$ por comparação com o nível basal de ativação de cada receptor, valor obtido de animais não tratados, naive (representados pela linha tracejada). 


\subsection{Participação de endocanabinóides e opióides endógenos no efeito da crotalfina}

Diante dos dados que sugerem a participação de receptores periféricos kappa opióide (KONNO et al., 2008) e canabinóide do tipo $\mathrm{CB}_{2}$ no efeito da crotalfina e de estudos preliminares indicando que a crotalfina não ativa diretamente os receptores opióides, uma vez que o peptídeo não é capaz de deslocar naloxona marcada $\left(\left[{ }^{3} \mathrm{H}\right]\right.$ naloxone) em estudos de "binding" (Correa, F., comunicação pessoal), a próxima etapa deste projeto foi avaliar se a participação dos receptores opióides e canabinóides no efeito da crotalfina ocorre então de maneira indireta, como uma conseqüência da liberação de opióides endógenos e de endocanabinóides, uma vez que tem sido demonstrado que drogas canabinóides podem ter seu efeito mediado pela liberação de opióides endógenos, da mesma maneira que opióides podem induzir a liberação de endocanabinóides.

\subsubsection{Envolvimento de endocanabinóides no efeito da crotalfina}

Para avaliar o envolvimento dos endocanabinóides no efeito da crotalfina, foram utilizados o Orlistat, um inibidor do diacilglicerol (precursor dos endocanabinóides, produzido a partir da hidrólise de fosfoinositídeos de membrana), e o MAFP, um inibidor da hidrolase amida de ácidos graxos (enzima que hidrolisa os endocanabinóides). Apesar das doses de 4 e $12 \mu \mathrm{g}$ de Orlistat não interferirem no efeito da crotalfina (Figura 13), a administração intraplantar de $4 \mu \mathrm{g}$ de MAFP induziu um aumento da atividade antinociceptiva de uma baixa dose de crotalfina $(0,04 \mu \mathrm{g} / \mathrm{kg})$ somente na pata tratada com o inidor (Figura 14). 
Figura 13 - Inibição do precursor dos endocanabinóides não interfere com o efeito da crotalfina

$\square$ Salina Crotalfina
Crotalfina + Orlistat $12 \mu \mathrm{g} /$ pata

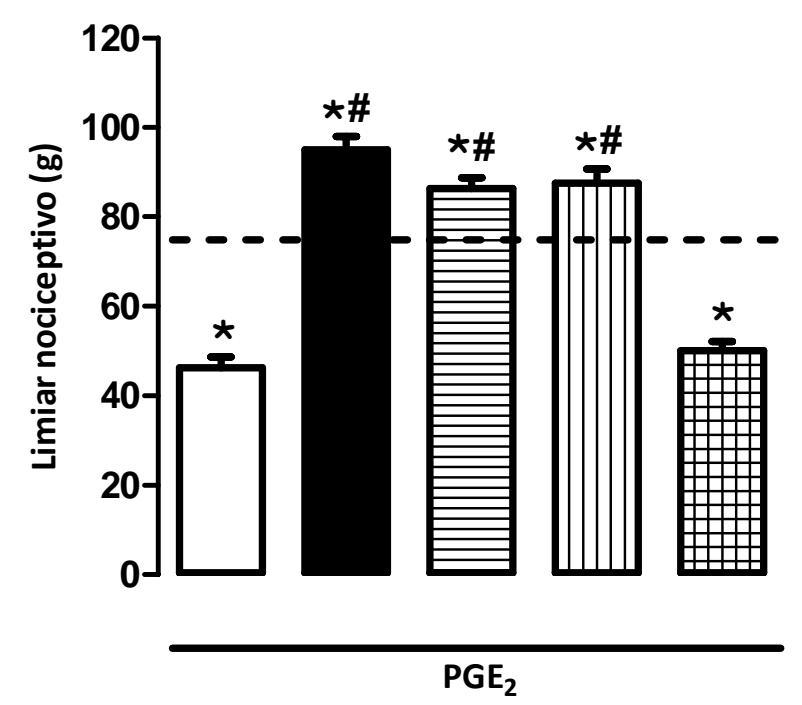

O limiar nociceptivo está representado pela força (em gramas) necessária para o animal apresentar a reação de "retirada" da pata. As medidas foram realizadas antes (medida inicial, representada pela linha tacejada) e 3 horas após a administração intraplantar de $100 \mathrm{ng}$ de $\mathrm{PGE}_{2}$ (medida final, pós-tratamento, representada pelas barras). Orlistat foi administrado via intraplantar 30 minutos antes do crotalfina $(1 \mu \mathrm{g} / \mathrm{kg}, 2$ horas após à injeção de $\mathrm{PGE}_{2}$ ). $\mathrm{O}$ grupo controle foi composto por animais tratados com $\mathrm{PGE}_{2}$ (i.pl.), salina estéril (p.o.) e veículo (i.pl., DMSO $6 \%$ em água destilada). Os dados representam a média \pm e.p.m. de pelo menos 5 animais por grupo. * p<0,05 por comparação com a medida basal e \# por comparação com o grupo controle. 
Figura 14 - A inibição de enzima metabolizadora de endocanabinóides potencializa o efeito da crotalfina

$\square$ Salina Crotalfina Crotalfina + MAFP Salina + MAFP

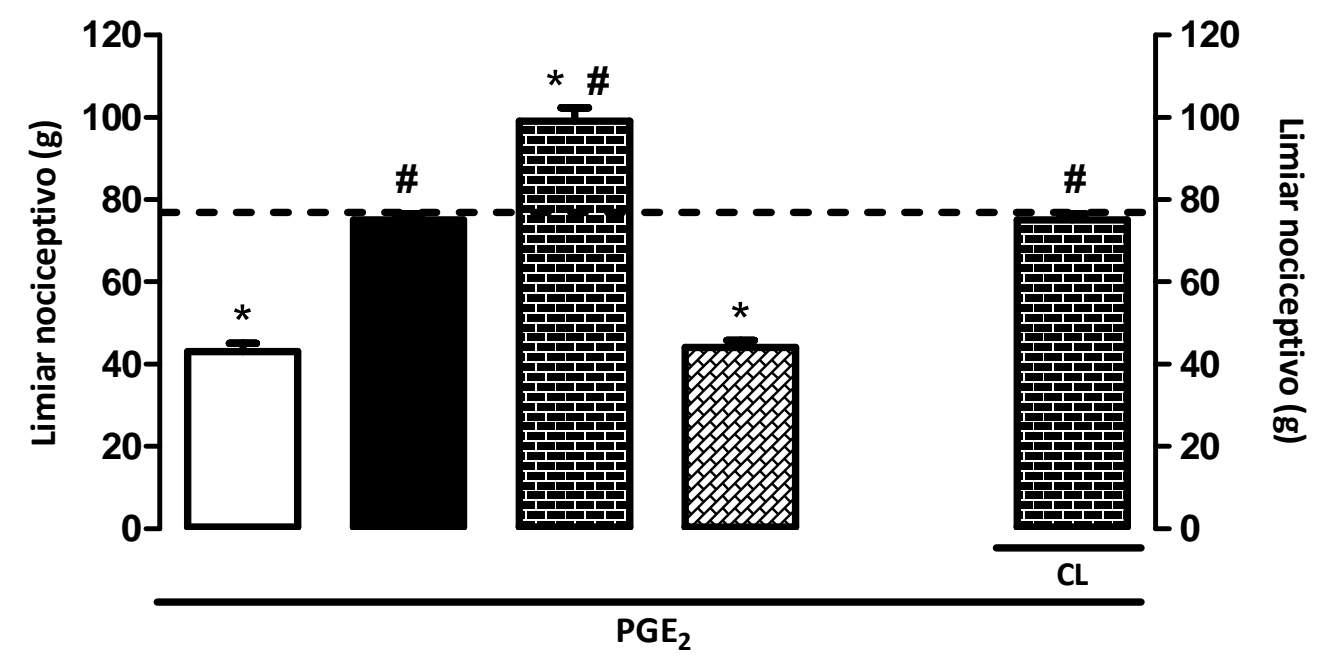

O limiar nociceptivo está representado pela força (em gramas) necessária para o animal apresentar a reação de "retirada" da pata. As medidas foram realizadas antes (medida inicial, representada pela linha tacejada) e 3 horas após a administração intraplantar de $100 \mathrm{ng}$ de $\mathrm{PGE}_{2}$ (medida final, pós-tratamento, representada pelas barras). MAFP (4 $\mu \mathrm{g} / \mathrm{pata})$ foi administrado via intraplantar 30 minutos antes do crotalfina $(0,04 \mu \mathrm{g} / \mathrm{kg}, 2$ horas após à injeção de $\mathrm{PGE}_{2}$ ). $\mathrm{O}$ grupo controle foi composto por animais tratados com $\mathrm{PGE}_{2}$ (i.pl.), salina estéril (p.o.) e veículo (i.pl., DMSO 6\% em água destilada). Os dados representam a média \pm e.p.m. de pelo menos 5 animais por grupo. ${ }^{*}$ p<0,05 por comparação com a medida basal e \# por comparação com o grupo controle. 
4.8.2 Envolvimento de opióides endógenos no efeito da crotalfina

Nestes ensaios, investigamos se a ativação dos receptores opióides ocorre de maneira indireta, como conseqüência da liberação de opióides endógenos. Ainda, investigamos se esta liberação seria induzida pela ativação dos receptores canabinóides, e se ela poderia ocorreria localmente, em células do tecido plantar de ratos, um estoque de opióides endógenos que contém tanto receptores opióides quanto canabinóides.

Para tanto, dois protocolos foram realizados: a) investigamos, in vivo, a capacidade de anticorpos anti-opióides endógenos (anticorpos anti-endorfina, anticorpos anti-dinorfina e anticorpos anti-encefalina), injetados por via intraplantar, em interferir com a antinocicepção induzida pela crotalfina; e b) determinamos a concentração de opióides liberados no sobrenadante de tecido plantar de ratos incubado com crotalfina, na presença e ausência de antagonistas de receptores canabinóides, utilizando ensaios de ELISA.

\subsubsection{Teste comportamental, in vivo}

A contribuição de peptídeos opióides endógenos para a antinocicepção induzida pela crotalfina foi investigada utilizando-se anticorpos específicos para cada opióide endógeno. Assim, analisamos, in vivo, a capacidade de anticorpos anti- $\beta$-endorfina $(0,05 ; 0,5$ e 5 $\mu \mathrm{g} /$ pata), anti- met-encefalina $(0,1 ; 1 ; 10$ e $50 \mu \mathrm{g} /$ pata $)$ e anti- dinorfina $\mathrm{A}(0,01 ; 0,1$ e 1 $\mu \mathrm{g} /$ pata), injetados por via intraplantar, em interferir com a antinocicepção induzida pela crotalfina durante a vigência de hiperalgesia induzida pela $\mathrm{PGE}_{2}$.

Os dados da figura 15 demonstram que a administração intraplantar de anticorpos anti$\beta$-endorfina e anti- met-encefalina não foram capazes de interferir no efeito da crotalfina. Por outro lado, o anticorpo anti-dinorfina A reverteu completamente a antinocicepção induzida pela crotalfina apenas na pata tratada, sem alterar o efeito antinociceptivo deste peptídeo na pata contralateral. 
Figura 15 - Atividade antinociceptiva da crotalfina na vigência de hiperalgesia induzida por $\mathrm{PGE}_{2}$ é dependente de dinorfina $\mathrm{A}$

A

$\square$ Salina $\quad$ Crotalfina Crotalfina + anti - $\beta$-endorfina 0,05 $\mu \mathrm{g} /$ pata

UII Crotalfina + anti - $\beta$-endorfina $0,5 \mu \mathrm{g} /$ pata Crotalfina + anti - $\beta$-endorfina $5 \mu \mathrm{g} /$ pata

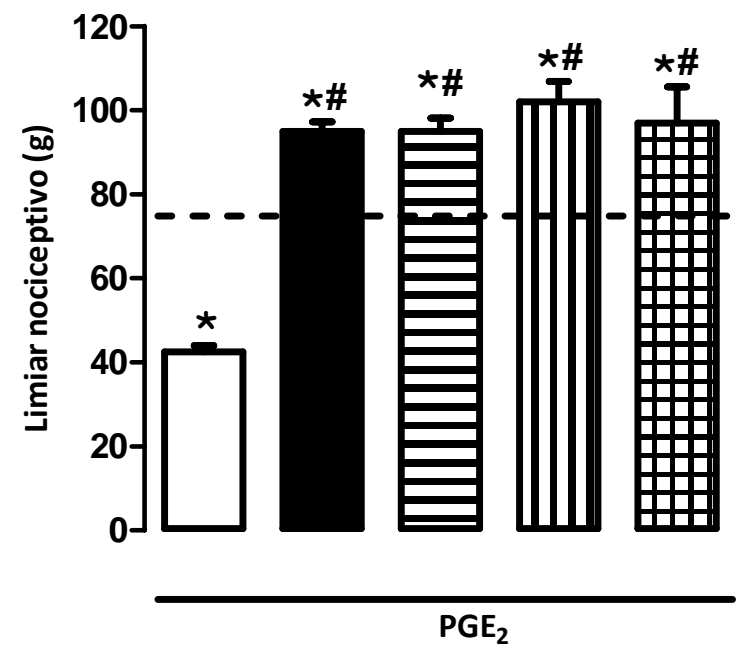

B
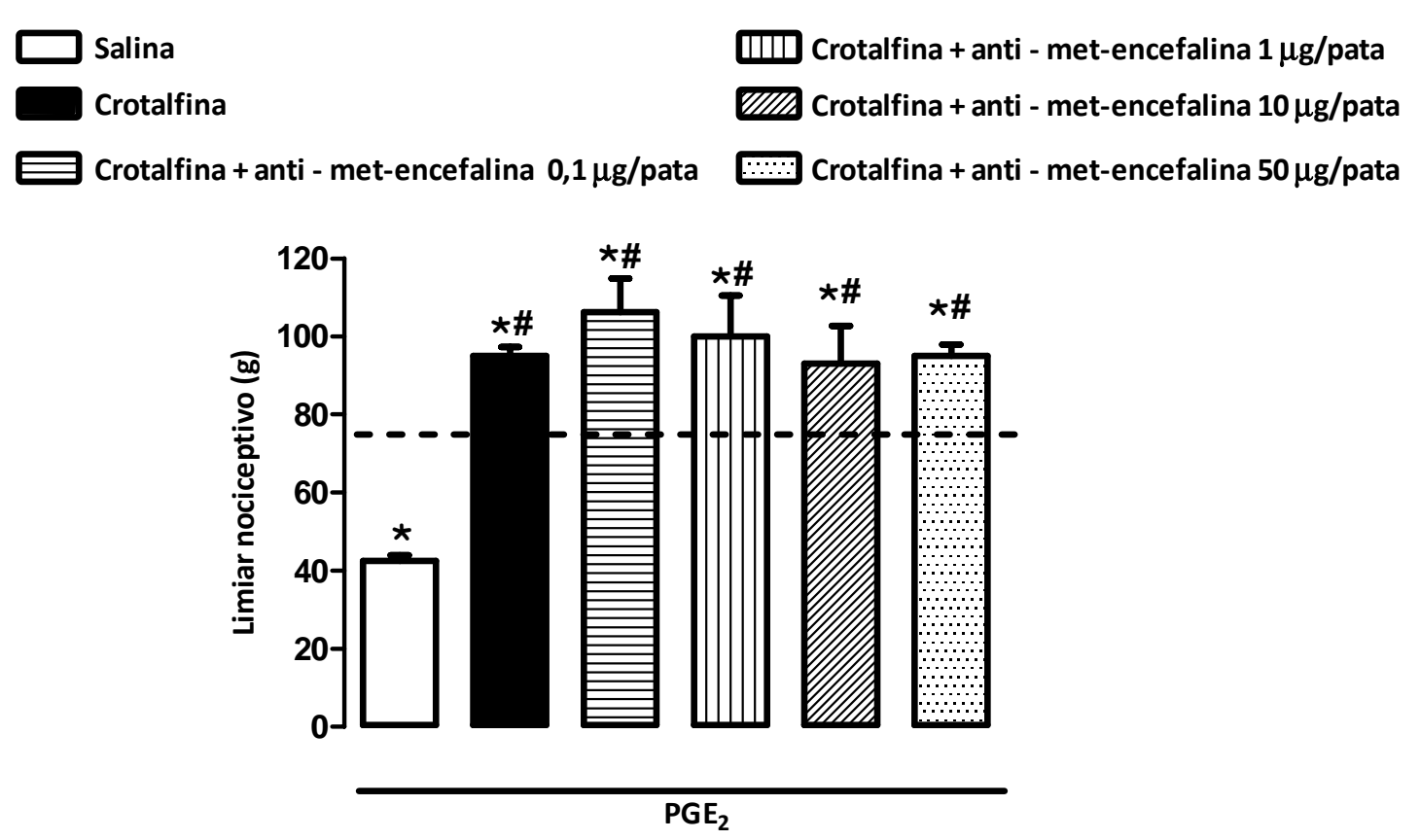
C

$\begin{array}{ll}\square \text { Calina } & \text { Crotalfina } \\ \square \text { Crotalfina + anti - dinorfina A 0,1 } \mu \mathrm{g} / \text { pata } & \mathbb{W} \text { Crotalfina + anti - dinorfina A } 1 \mu \mathrm{g} / \mathrm{pata}\end{array}$

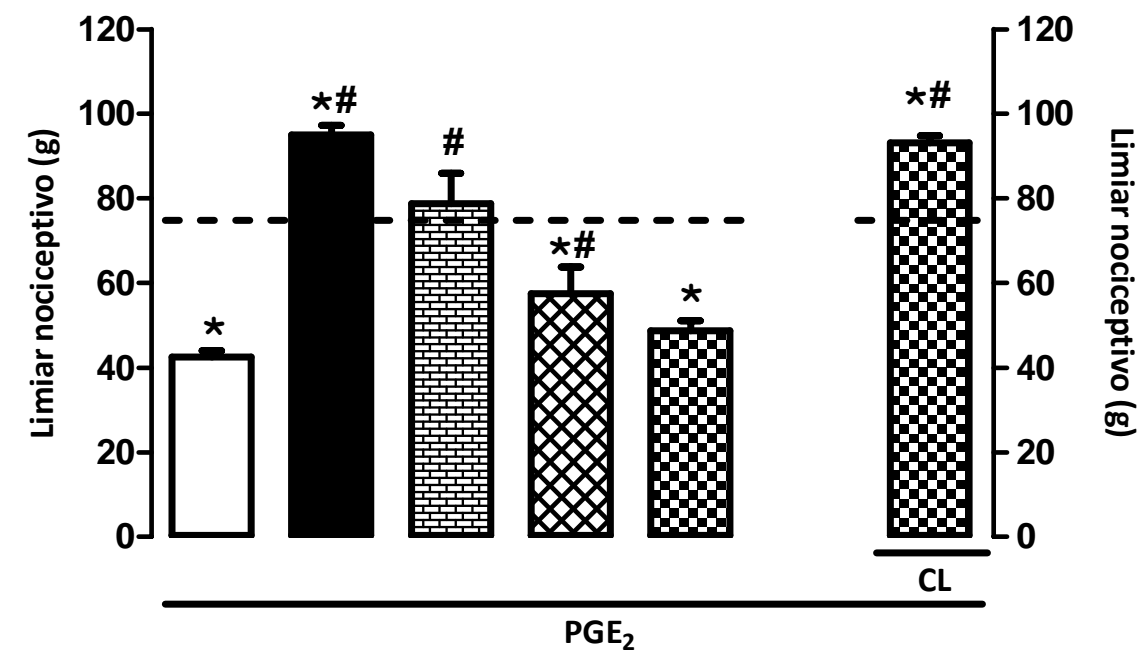

O limiar nociceptivo está representado pela força (em gramas) necessária para o animal apresentar a reação de "retirada" da pata. As medidas foram realizadas antes (medida inicial, representada pela linha tacejada) e 3 horas após a administração intraplantar de $100 \mathrm{ng}$ de $\mathrm{PGE}_{2}$ (medida final, pós-tratamento, representada pelas barras). Os anticorpos anti- $\beta$-endorfina $(0,05 ; 0,5$ e $5 \mu \mathrm{g} /$ pata, painel $\mathbf{A})$, anticorpos anti- met-encefalina $(0,1 ; 1 ; 10$ e 50 $\mu \mathrm{g} / \mathrm{pata}$, painel B) e anticorpos anti- dinorfina $\mathrm{A}(0,01 ; 0,1$ e $1 \mu \mathrm{g} / \mathrm{pata}$, painel $\mathbf{C})$ foram administrados via intraplantar 30 minutos antes do crotalfina $\left(1 \mu \mathrm{g} / \mathrm{kg}, 2\right.$ horas após à injeção de $\left.\mathrm{PGE}_{2}\right)$. O grupo controle foi composto por animais tratados com $\mathrm{PGE}_{2}$ (i.pl.), salina estéril (p.o.) e veículo (i.pl., salina estéril). Os dados representam a média \pm e.p.m. de pelo menos 5 animais por grupo. $*$ p $<0,05$ por comparação com a medida basal e \# por comparação com o grupo controle. 
Corroborando os dados anteriores que mostram a participação de opióides endógenos no efeito da crotalfina, a administração intraplantar de $10 \mu \mathrm{g} /$ pata de captopril, um inibidor da enzima peptidil dipeptidase que degrada opióides endógenos, induziu um aumento da atividade antinociceptiva de uma baixa dose de crotalfina $(0,04 \mu \mathrm{g} / \mathrm{kg})$ somente na pata tratada com o inibidor, sem alterar o efeito antinociceptivo deste peptídeo na pata contralateral (Figura 16).

\section{Figura 16 - A inibição de enzima metabolizadora de dinorfina A potencializa o efeito antinociceptivo da crotalfina}
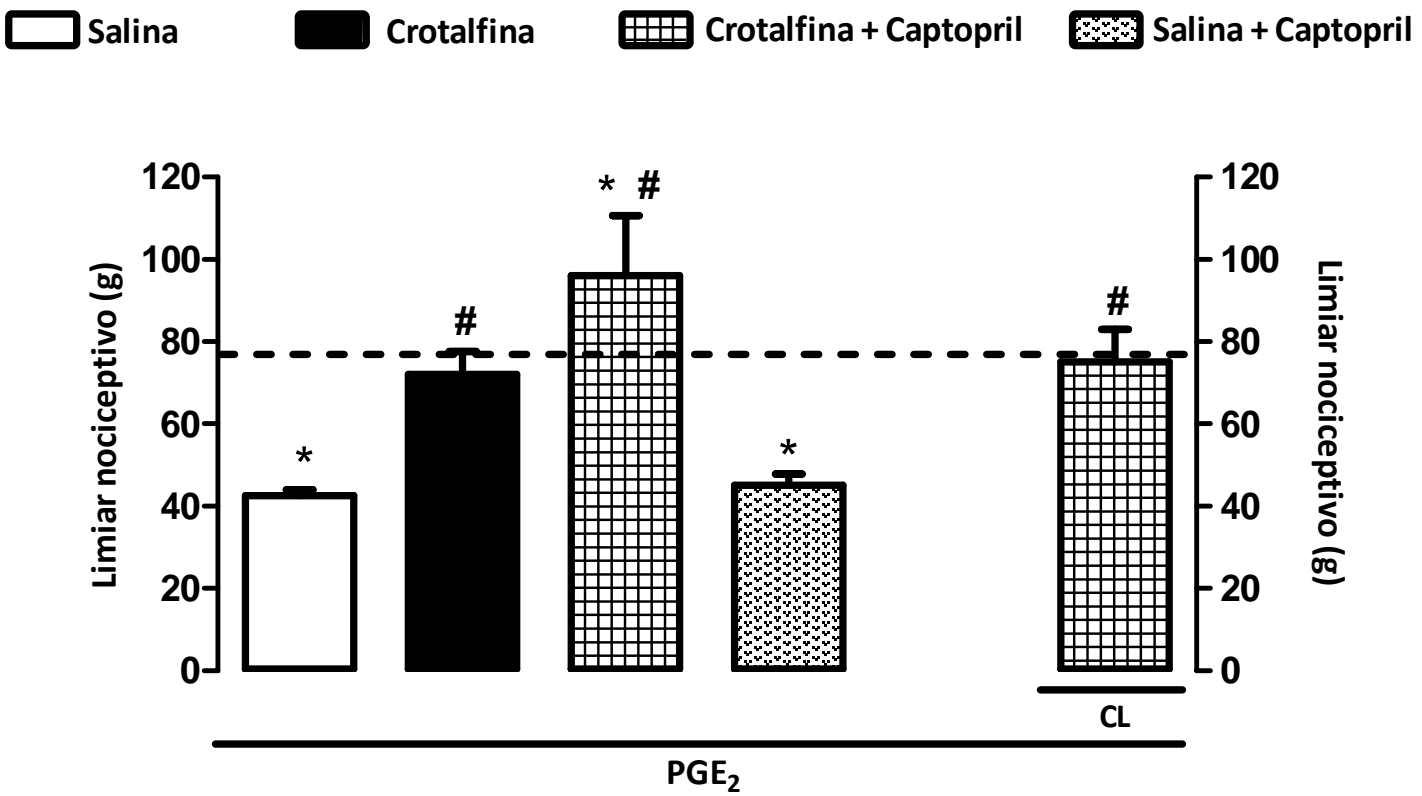

O limiar nociceptivo está representado pela força (em gramas) necessária para o animal apresentar a reação de "retirada" da pata. As medidas foram realizadas antes (medida inicial, representada pela linha tacejada) e 3 horas após a administração intraplantar de $100 \mathrm{ng}$ de $\mathrm{PGE}_{2}$ (medida final, pós-tratamento, representada pelas barras). Captopril $(10 \mu \mathrm{g} /$ pata) foi administrado via intraplantar 30 minutos antes do crotalfina $(0,04 \mu \mathrm{g} / \mathrm{kg}, 2$ horas após à injeção de $\mathrm{PGE}_{2}$ ). $\mathrm{O}$ grupo controle foi composto por animais tratados com $\mathrm{PGE}_{2}$ (i.pl.), salina estéril (p.o.) e veículo (i.pl., DMSO 6\% em água destilada). Os dados representam a média \pm e.p.m. de pelo menos 5 animais por grupo. ${ }^{*}$ p<0,05 por comparação com a medida basal e \# por comparação com o grupo controle. 
Diante dos nossos resultados que demonstram a participação de receptores periféricos kappa opióide, canabinóide do tipo $\mathrm{CB}_{2}$ e, ainda, do peptídeo opióide endógeno dinorfina $\mathrm{A}$ no efeito antinociceptivo da crotalfina, um ensaio imunoenzimático foi realizado para avaliar se a liberação de dinorfina seria dependente da ativação de receptores $\mathrm{CB}_{2}$, e se ela poderia ocorrer de tecidos periféricos locais previamente sensibilizados.

A figura 17 demonstra a concentração de opióides endógenos liberados no sobrenadante de tecido dérmico da pata de ratos previamente sensibilizados com a administração intraplantar de $\mathrm{PGE}_{2}$. O resultado demonstra mais uma vez que a crotalfina induz a liberação, pelo tecido plantar de ratos sensibilizados por $\mathrm{PGE}_{2}$, somente de dinorfina A $(2,6 \mathrm{nM}: 7,15 \mathrm{ng} / \mathrm{ml} \pm 1,51 ; 1 \mu \mathrm{M}: 7,05 \mathrm{ng} / \mathrm{ml} \pm 1,55$; em comparação ao nível basal observado em amostras de animais nä̈ve não tratadas e coletadas no mesmo dia de experimento, $0,64 \mathrm{ng} / \mathrm{ml} \pm 0,03)$.

Vale a pena ressaltar que as duas concentrações de crotalfina não induzem liberação de $\beta$-endorfina e de met-encefalina. Nessas condições experimentais, representando uma hiperalgesia aguda, a crotalfina não interferiu nos níveis basais de liberação de met-encefalina e inibiu a liberação de $\beta$-endorfina. 
Figura 17 - A liberação de dinorfina A do tecido plantar de ratos pré-tratados com $\mathrm{PGE}_{2}$ induzida pela crotalfina é dependente de receptores canabinóides locais do tipo $\mathrm{CB}_{2}$
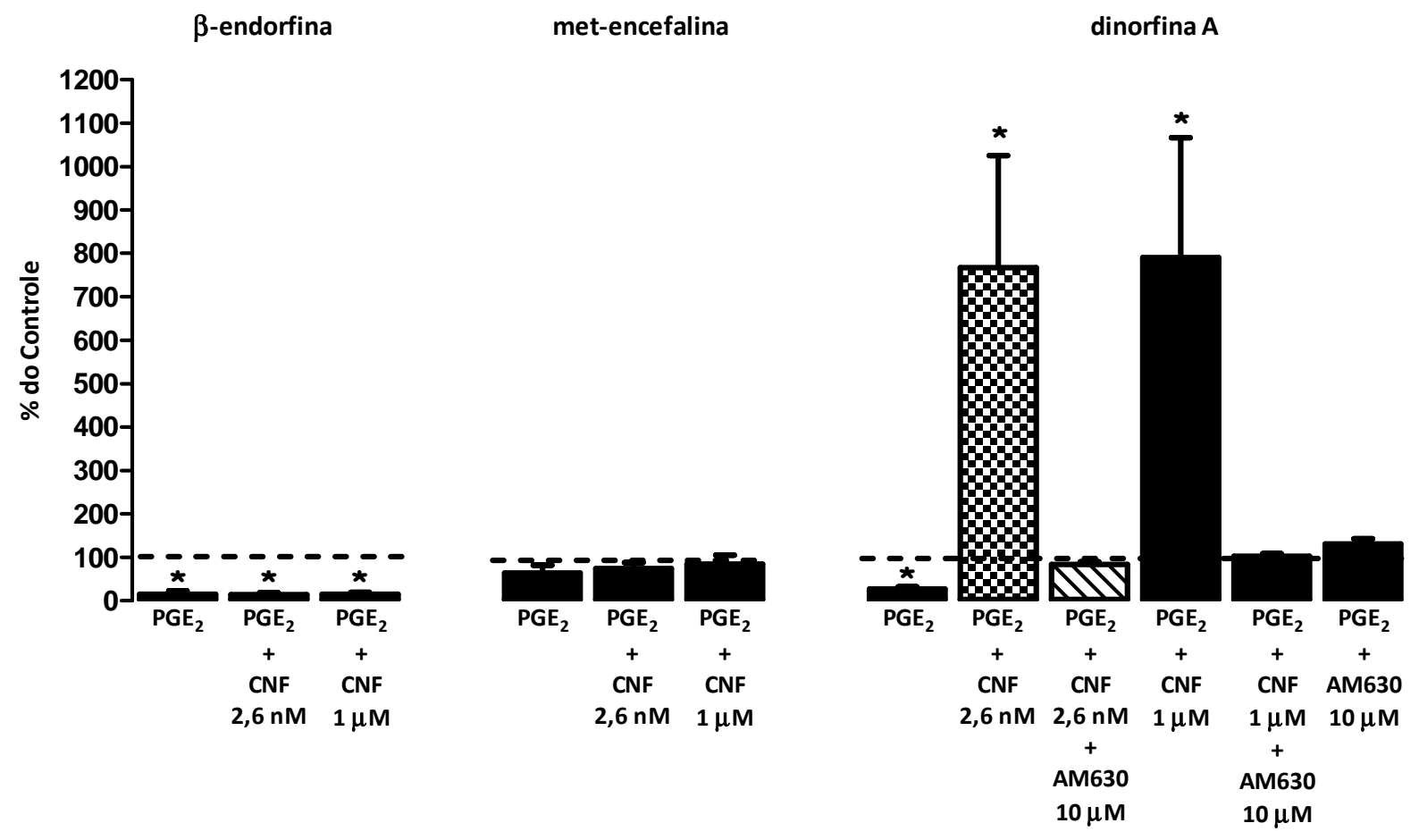

Para esse ensaio, ratos foram tratados com $100 \mathrm{ng}$ de $\mathrm{PGE}_{2}$, i.pl. A superfície do tecido plantar desses animais previamente sensibilizados foi cuidadosamente coletado 2 horas após o tratamento algogênico e mantido por 30 minutos em solução de Hank's contendo $1 \%$ de soro fetal bovino e o respectivo tratamento farmacológico à 37 ${ }^{\circ} \mathrm{C}$. Um punch de biópsia de pele (4 mm de diâmetro) foi utilizado para preparar as amostras de tecido. $\beta$ endorfina, met-encefalina e dinorfina A contidos no sobrenadante foi quantificado utilizando kit de imunoensaio comercial. * p $<0,05$ por comparação com os níveis de concentração de opióide endógeno basal, obtido de amostras de tecido plantar submetidos à incubação com tratamento farmacológico.

\subsection{Atividade da crotalfina sobre os receptores canabinóides}

A fim de determinar se o efeito da crotalfina sobre o sistema canabinóide ocorreria de maneira direta, por ligação aos receptores canabinóides, realizamos ensaio de binding indireto sobre os receptores $\mathrm{CB}_{1}$ e $\mathrm{CB}_{2}$, segundo metodologia descrita por Chianese et al. (CHIANESE et al., 2011).

Diferentes concentrações da ordem de nano e micromolar de crotalfina não demonstraram capacidade de competir significativamente com o agonista canabinóide radiomarcado no ensaio de binding em $\mathrm{CB}_{1}$. Além disso, não foi possível construir uma curva concentração - efeito e determinar outros importantes parâmetros farmacológicos como o $\mathrm{IC}_{50}$ e $\mathrm{K} i$ - vide tabela 2. 
Tabela 2 - Ensaio de binding competitivo da crotalfina sobre receptores tipo $\mathbf{C B}_{1}$

\begin{tabular}{cccc}
\hline & $\begin{array}{c}\text { \% de indução de } \\
\text { deslocamento do }\end{array}$ & $\begin{array}{c}\mathbf{I C}_{\mathbf{5 0}} \text { sobre } \\
\text { receptor } \mathbf{C B}_{\mathbf{1}}\end{array}$ & $\mathbf{K i}$ \\
Molar de & agonista & $(\boldsymbol{\mu M})$ & \\
crotalfina & radiomarcado & & \\
$(\boldsymbol{\mu M})$ & ${ }^{[3 \mathbf{H}]} \mathbf{C P 5 5 , 4 9 0}$ & $>25$ & $>25$ \\
$\mathbf{2 5}$ & $22,64 \%$ & & \\
$\mathbf{1 0}$ & $20,85 \%$ & & \\
$\mathbf{5}$ & $4,26 \%$ & & \\
$\mathbf{1}$ & $12,83 \%$ & & \\
$\mathbf{0 , 1}$ & $23,80 \%$ & & \\
$\mathbf{0 , 0 1}$ & $19,98 \%$ & & \\
$\mathbf{0 , 0 0 1}$ & $32,53 \%$ & & \\
$\mathbf{0 , 0 0 0 1}$ & $23,60 \%$ & & \\
\hline
\end{tabular}

Nota: $\mathrm{IC}_{50}$ : concentração de ligante de competição que desloca $50 \%$ da ligação específica de radioligante

$\mathrm{Ki}$ : inibição absoluta constante, convertendo $\mathrm{IC}_{50}$ e utilizando a equação clássica de ChengPrusoff (CHENG; PRUSOFF, 1973).

Por outro lado, no ensaio sobre receptores canabinóides do tipo $\mathrm{CB}_{2}$, concentrações nano molares de crotalfina demonstraram capacidade significativa de deslocamento do mesmo agonista canabinóide clássico utilizado no teste anterior, gerando uma curva concentração - resposta sigmoide, perfil farmacológico clássico para estudos de binding (Figura 19). Concentrações de ordem micro molar também foram testadas: 1; 10 e $25 \mu \mathrm{M}$.

A concentração de $1 \mu \mathrm{M}$ induziu 90,39 \% (+/- 3,45 \%) de deslocamento do ${ }^{\left[{ }^{3 H]}\right.} \mathrm{CP} 55,490$, gerando estatisticamente a formação de um platô na resposta máxima da curva concentração - efeito, vide figura 19.

Em posse destes dados, foi possível determinar a menor concentração molar de ligação máxima, o $\mathrm{IC}_{50}$ e o $\mathrm{K} i$ da crotalfina sobre receptores $\mathrm{CB}_{2}$ - vide tabela 2. Um decaimento da capacidade de binding da crotalfina em receptores do tipo $\mathrm{CB}_{2}$ foi observada nas concentrações de $10 \mu \mathrm{M}(75,29 \%)$ e $25 \mu \mathrm{M}(33,31 \%)$. 
Tabela 3 - Dados farmacológicos do ensaio de binding competitivo da crotalfina sobre receptores tipo $\mathrm{CB}_{2}$

\begin{tabular}{cccc}
\hline Menor & & & \\
concentração & $\%$ de indução de & IC $_{50}$ sobre & Ki \\
molar de & deslocamento do & receptor $\mathbf{C B}_{2}$ & $(\mathbf{n M})$ \\
atividade & agonista & $(\mathbf{n M})$ & \\
máxima de & radiomarcado & & \\
crotalfina & ${ }^{[3 \mathrm{H}]} \mathbf{C P 5 5 , 4 9 0}$ & & \\
$(\mathrm{nM})$ & & \\
\hline
\end{tabular}

$\begin{array}{llll}100 & 86.91 \% & 2.05+/-0.55 & 0.54+/-0.14\end{array}$

Nota: $\mathrm{IC}_{50}$ : concentração de ligante de competição que desloca $50 \%$ da ligação específica de radioligante

Ki: inibição absoluta constante, convertendo $\mathrm{IC}_{50}$ e utilizando a equação clássica de ChengPrusoff (CHENG; PRUSOFF, 1973).

Figura 18 - Curva sigmoidal concentração-resposta do ensaio de binding competitivo da crotalfina sobre receptores tipo $\mathrm{CB}_{2}$

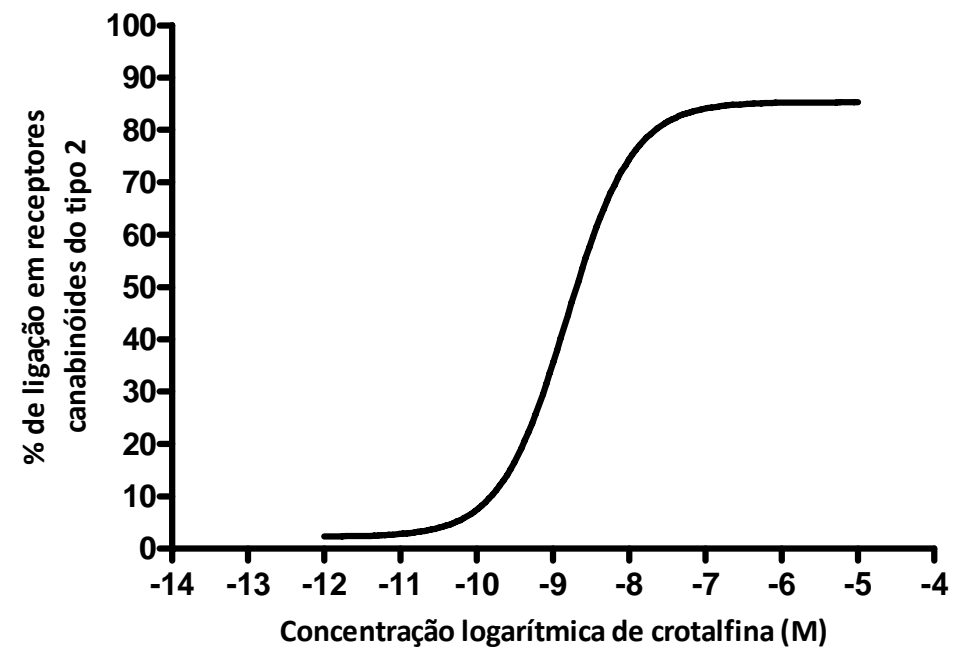

Membranas de células HEK-293 transfectadas com o receptor $\mathrm{CB}_{2}$ humano recombinante $(\mathrm{Bmax}=4,7$ proteína $\mathrm{pmol} / \mathrm{mg})$ foram incubadas com o ligando de afinidade elevada radiomarcada ${ }^{[3 \mathrm{H}]} \mathrm{CP}-55940(0,084 \mathrm{nM}, \mathrm{Kd}=$ 0,31 nM, para os receptores $\mathrm{CB}_{2}$ ) e deslocado com $10 \mu \mathrm{M}$ WIN 55212-2 como o competidor heterólogo para a ligação não especifica (Ki valor de $2,1 \mathrm{nM}$ para os receptores $\mathrm{CB}_{2}$ ). Os dados representam os valores médios de pelo menos três experiências separadas realizadas em triplicata e são expressos como Ki (nM). Os valores de Ki foram calculados por aplicação da equação de Cheng-Prusoff aos valores de $\mathrm{IC}_{50}$ (obtido por GraphPad) para o deslocamento do radioligante ligado por concentrações crescentes do composto de ensaio. 


\section{DISCUSSÃO}

A dor é um fenômeno que afeta todas as pessoas, em alguma fase de sua vida. Apesar dos estudos relacionados aos mecanismos da dor e seu controle terem avançado nos últimos anos, muitas pessoas ainda sofrem com a falta de controle de alguns tipos de dor ou ainda com efeitos adversos severos de alguns tratamentos. Assim, a busca por novas drogas capazes de controlar a dor tem sido constante.

Nesse sentido, foi demonstrado recentemente o efeito antinociceptivo da crotalfina, um peptídeo de 14 aminoácidos com ação analgésica tipo opióide, sintetizado a partir da seqüência de um composto analgésico purificado do veneno de serpentes Crotalus durissus terrificus (KONNO et al., 2008). Os estudos realizados com a crotalfina demonstraram que ela era capaz de reproduzir os dados obtidos com o veneno bruto: induzir antinocicepção de longa duração mediada pela ativação de receptores opióides do tipo kappa, em modelos de dor aguda (KONNO et al., 2008) ou kappa e delta, em modelo de dor neuropática induzida por constrição do nervo ciático (GUTIERREZ et al., 2008). Em todos os modelos o efeito é de longa duração (2-3 dias nos modelos de dor crônica e 5 dias no modelo de hiperalgesia inflamatória) e pode ser observado após administração por diferentes vias (GUTIERREZ et al., 2008; KONNO et al., 2008).

É importante ressaltar que, apesar de acarretar analgesia revertida por antagonistas de receptores opióides, a sequência da crotalfina não apresenta similaridade com nenhum outro opióide conhecido (KONNO et al., 2008). Ainda, estudos preliminares indicam que a crotalfina não ativa diretamente os receptores opióides uma vez que o peptídeo não é capaz de deslocar naloxona marcada $\left(\left[{ }^{3} \mathrm{H}\right]\right.$ naloxone) em estudos de "binding" (Correa, F., comunicação pessoal). Assim, buscamos neste projeto investigar quais mecanismos estariam envolvidos na antinocicepção induzida pela crotalfina.

Vários agentes indutores de hipernocicepção têm sido utilizados experimentalmente, tanto para o estudo de novas drogas, como para investigação de vias de dor e sua sinalização, dentre eles, a prostaglandina $\mathrm{E}_{2}\left(\mathrm{PGE}_{2}\right)$. $\mathrm{A} \mathrm{PGE}_{2}$ não induz resposta inflamatória, mas age sensibilizando diretamente o neurônio sensitivo primário, pela interação com receptores acoplados a segundos-mensageiros (DRAY, 1995), causando diminuição do limiar de dor dos animais (DRAY, 1995; FERREIRA; LORENZETTI, 1981; FERREIRA; NAKAMURA, 1979a; b; c). Esta hiperalgesia é decorrente do aumento dos níveis intracelulares de AMPc e $\mathrm{Ca}^{+2}$ (FERREIRA; NAKAMURA, 1979a; TAIWO; LEVINE, 1991), com conseqüente despolarização da membrana celular e transmissão do impulso nociceptivo (FERREIRA; 
LORENZETTI, 1994). Adicionalmente ao aumento dos níveis de AMPc, foi demonstrado que as prostaglandinas podem aumentar a sensibilização dos neurônios aferentes primários, por tornar funcionais os canais de $\mathrm{Na}^{+}$resistentes à tetrodotoxina, via ativação de proteínoquinase A (ENGLAND et al., 1996). Portanto, seu efeito hiperalgésico é resultante da sensibilização direta dos nociceptores e não de uma resposta inflamatória. Assim, a evidência de efeito analgésico de um fármaco, sobre este modelo de hiperalgesia, reflete ação direta deste fármaco sobre a atividade da fibra nervosa sensitiva aferente, responsável pela condução do impulso nociceptivo. Em nossos estudos foi utilizado o modelo de hiperalgesia aguda induzida por prostaglandina $\mathrm{E}_{2}$, que foi avaliada em ratos utilizando o modelo de pressão de pata.

Animais sensibilizados com $\mathrm{PGE}_{2}$ que foram tratados com o peptídeo sintético por via oral apresentaram antinocicepção de forma dose-dependente. Uma vez que dados anteriores do nosso grupo demonstraram o envolvimento de receptores opióides neste efeito (GUTIERREZ et al., 2008; KONNO et al., 2008), a dose de crotalfina selecionada inicialmente para os ensaios subseqüentes $(1 \mu \mathrm{g} / \mathrm{kg}$ em ratos) foi aquela capaz de acarretar alteração no limiar nociceptivo dos animais semelhante à alteração induzida pela administração de dose padrão de morfina $(5 \mathrm{mg} / \mathrm{kg}$ ), protótipo de droga opióide e nosso controle positivo.

Como citado anteriormente, apesar dos receptores opióides estarem envolvidos no efeito da crotalfina, estudos preliminares indicam que a crotalfina não ativa diretamente os receptores opióides uma vez que o peptídeo não é capaz de deslocar naloxona marcada $\left(\left[{ }^{3} \mathrm{H}\right]\right.$ naloxone) em estudos de "binding" (Correa, F., comunicação pessoal). Assim, buscamos neste projeto investigar quais mecanismos estariam envolvidos na antinocicepção induzida pela crotalfina.

Apesar de moléculas opióides e canabinóides se ligarem a diferentes receptores, vários dados da Literatura têm proposto uma estreita relação entre os sistemas opióides e canabinóides. Tanto os receptores opióides quanto os canabinóides produzem antinocicepção através de mecanismos dependentes de proteína G (ANAND et al., 2009; CICHEWICZ, 2004; PIOMELLI, 2003). Ainda, ambos os sistemas atuam em locais comuns, sendo que seus receptores estão co-distribuídos em áreas importantes para o controle da dor como o corno dorsal da medula espinhal, substância cinzenta periaquedutal, núcleo da rafe e núcleo talâmico centro-medial. Estes sistemas, ainda, parecem potencializar um ao outro, indicando uma interação sinérgica entre eles (CICHEWICZ, 2004). 
Diante dessas evidências e dos dados anteriores do nosso grupo que demonstraram que a crotalfina não ativa diretamente os receptores opióides, investigamos o possível efeito da crotalfina sobre o sistema canabinóide.

O sistema endocanabinóide é constituído pelos receptores canabinóides, os seus ligantes endógenos, os endocanabinóides, e as proteínas envolvidas na sua síntese e inativação. Por isso, inicialmente ensaios foram realizados analisando uma curva doseresposta dos agonistas específicos para estes receptores, administrados por via intraplantar, para se determinar a dose capaz de acarretar analgesia local de mesma intensidade que a crotalfina. Determinada esta dose, foi traçada outra curva dose-resposta dos antagonistas canabinóides sobre seu agonista específico, administrados pela via intraplantar, a fim de encontrar qual dose de antagonista reverte o efeito do seu agonista. Feito isso, foi avaliada a capacidade dos antagonistas $\mathrm{CB}_{1}$ e $\mathrm{CB}_{2}$ interferirem no efeito da crotalfina.

Os resultados demonstram que a injeção intraplantar do antagonista $\mathrm{CB}_{1}$ reverteu parcialmente o efeito da crotalfina, enquanto o antagonista $\mathrm{CB}_{2}$, administrado pela mesma via, inibiu completamente o efeito antinociceptivo do peptídeo no modelo de hiperalgesia aguda induzida por $\mathrm{PGE}_{2}$. Esse dados sugerem que receptores canabinóides periféricos do tipo 1 e, principalmente, do tipo 2 estão envolvidos no efeito antinociceptivo da crotalfina.

Uma vez que os resultados demonstrados até o momento indicam a participação de receptores canabinóides periféricos, principalmente do tipo $\mathrm{CB}_{2}$, no efeito antinociceptivo da crotalfina e dados anteriores do nosso grupo demonstram a participação de receptores opióides locais do tipo kappa neste efeito, investigamos a alteração no estado conformacional dos receptores canabinóides e opióides, a fim de se confirmar qual receptor apresentava aumento na sua atividade após o tratamento dos animais com crotalfina. Para tanto, foram realizados ensaios de imunomarcação em slice (fatia), no tecido da pata de ratos, utilizando anticorpos fluorescentes sensíveis à conformação específica ativada de receptores $\mathrm{CB}_{1}, \mathrm{CB}_{2}$, mu, kappa e delta fosforilados (GUPTA et al., 2007).

Segundo Gupta e colaboradores (GUPTA et al., 2007), anticorpos sensíveis ao estado conformacional de receptores receptores acoplados à proteína $\mathrm{G}$ distinguem mudanças conformacionais destes receptores, uma vez que são capazes de reconhecer a porção Nterminal, exposta somente quando o receptor se encontra no seu estado ativado (GUPTA et al., 2006) (Proteimax Biotecnologia, Cotia, SP, Brasil). Uma vez que existe a possibilidade de o tratamento farmacológico ( $\mathrm{PGE}_{2}$ e crotalfina) alterar a expressão de receptores opióides e canabinóides totais, os dados foram normalizados. Para tanto, a quantificação de receptores ativados levou em consideração o número de receptores totais expressos após cada 
tratamento. Para representação dos resultados, a ativação basal de cada receptor foi considerada $100 \%$.

Nossos dados demonstram que a administração intraplantar de $0,0006 \mu \mathrm{g}$ de crotalfina induziu um aumento no nível de ativação de receptores $\mathrm{CB}_{2}$ e kappa opióide no tecido plantar de ratos pré-tratados com $\mathrm{PGE}_{2}$, sem alterar o estado de ativação dos receptores $\mathrm{CB}_{1}$ e delta, confirmando a participação de ambos receptores canabinóide e opióide no efeito do peptídeo analgésico, reforçando os dados de Literatura que demonstram uma estreita relação entre estes sistemas na modulação da nocicepção (ANAND et al., 2009; CICHEWICZ, 2004).

Com relação ao receptor $m u$, este teve sua ativação inibida pela administração da $\mathrm{PGE}_{2}$, sendo que esta inibição não foi alterada pela crotalfina. Diversos trabalhos da Literatura demonstram que durante respostas inflamatórias, a eficácia de agonistas opióides pode variar de acordo com a natureza do estímulo nocivo ou do tipo de injúria periférica (MILLAN, 1986). Ainda, dependendo da natureza e do estágio da reação inflamatória, diferentes tipos de receptores opióides podem ser ativados (STEIN, 1993; STEIN; LANG, 2009). Além disso, diferentes estímulos nociceptivos periféricos podem ativar e/ou inibir a transcrição e/ou expressão de diferentes receptores opióides na fibra nociceptiva (ANTONIJEVIC et al., 1995; OBARA et al., 2009; STEIN, 1993; STEIN; LANG, 2009).

Nesse sentido, dados anteriores de nosso grupo demonstraram que a injeção intraplantar de $\mathrm{PGE}_{2}$, em ratos, aumenta a expressão gênica e proteica de receptores opióides $\mu$ tanto no gânglio da raiz dorsal quanto no nervo da pata, sem interferir com a ativação destes receptores (Zambelli et al, submetido). Já no presente ensaio, a crotalfina não foi capaz de alterar a inibição da atividade dos receptores $m u$ induzida pela $\mathrm{PGE}_{2}$. A diferença na natureza do material avaliado poderia explicar estes resultados distintos, uma vez que a avaliação da ativação de receptors $\mu$, por estes autores, foi realizada no gânglio da raiz dorsal e no nervo da pata isolado, enquanto nossos estudos levaram em consideração todo tecido da pata, incluindo queratinócitos e outros componentes da pele como células residentes e inflamatórias e terminações nociceptivas. De qualquer forma, o resultado do ensaio de imunofluorescência confirma a participação de receptores $\mathrm{CB}_{2}$ e kappa periféricos no efeito da crotalfina, já observada nos ensaios comportamentais in vivo (GUTIERREZ et al., 2008; KONNO et al., 2008).

Diante dos dados que demonstram a participação de receptores periféricos kappa opióide (KONNO et al., 2008) e canabinóide do tipo $\mathrm{CB}_{2}$ no efeito da crotalfina, a próxima etapa deste projeto foi avaliar se a participação dos receptores opióides e canabinóides no 
efeito da crotalfina ocorre então de maneira indireta, como uma conseqüência da liberação de opióides endógenos e de endocanabinóides.

Dados da literatura relatam que diversos compostos endógenos que se ligam seletivamente aos receptores canabinóides têm sido identificados, sendo os principais a anandamida ( $\mathrm{N}$-aracdonil-etanolamina, ligante preferencial de receptor $\mathrm{CB}_{1}$ ) e o 2aracdonilglicerol (2-AG ligante preferencial de receptor $\mathrm{CB}_{2}$ ). Desde a descoberta da anandamida, diversas moléculas formadas por ácidos graxos com atividade agonista total ou parcial sobre o receptor $\mathrm{CB}_{1}$ e/ou $\mathrm{CB}_{2}$ têm sido extraídas de tecidos animais ou quimicamente sintetizadas. Estas moléculas, entretanto, não só podem modular diretamente a sinalização do receptor canabinóide, como também podem afetar uma variedade de proteínas, incluindo canais iônicos (ex: TRPV1), receptores acoplados à proteína G (GPCRs) (ex: receptores para a serotonina) e enzimas (MECHOULAM et al., 1998).

As principais enzimas responsáveis pela hidrólise da anandamida e da 2-AG são a amida hidrolase de ácidos graxos (FAAH) e a lipase monoacilglicerol (MAGL), respectivamente. Os dois endocanabinoides são degradados tanto de forma pré-sináptica (2AG) como pós-sináptica (anandamida). Por isso, tanto a FAAH quanto a MAGL emergiram como importantes alvos farmacológicos com potencial terapêutico promissor (DI MARZO et al., 2004; PIOMELLI, 2003).

Endocanabinóides são rapidamente inativados. Portanto, o papel da FAAH e monoacilglicerol lipase na inativação de endocanabonóides sugere que os inibidores destas enzimas poderiam ser usados para aumentar a atividade endocanabinóide. Apesar de os inibidores da FAAH induzirem antinocicepção em modelos experimentais de dor inflamatória e crônica (DA FONSECA PACHECO et al., 2008; JAYAMANNE et al., 2006), dados da literatura demonstram que o MAFP por si só não altera a hiperalgesia induzida por $\mathrm{PGE}_{2}$.

Similar aos neurônios, uma via biossintética endocanabinóide tem sido descrita em células do sistema imunológico (principalmente macrófagos) e seus efeitos periféricos envolvem principalmente a participação de receptores $\mathrm{CB}_{2}$ locais (BISOGNO et al., 1997; PESTONJAMASP; BURSTEIN, 1998). No entanto, a contribuição dos endocanabinóides derivados de células imunes na modulação da dor ainda não foi totalmente elucidado (DI MARZO et al., 2004; DI MARZO et al., 1999).

A participação de endocanabinóides no efeito da crotalfina foi avaliada utilizando dois tratamentos farmacológicos: o Orlistat, um inibidor do diacilglicerol (precursor dos endocanabinóides, produzido a partir da hidrólise de fosfoinositídeos de membrana), a fim de se verificar se este inibidor é capaz de interferir com a antinocicepção induzida pela 
crotalfina, e o MAFP (metil araquidonil fluorofosfonado), um inibidor da hidrolase amida de ácidos graxos (enzima que hidrolisa os endocanabinóides), a fim de se verificar se este inibidor é capaz de potencializar a antinocicepção induzida pela crotalfina.

Apesar das doses de 4 e $12 \mu \mathrm{g}$ de Orlistat não interferirem no efeito da crotalfina, a administração intraplantar de $4 \mu \mathrm{g}$ de MAFP induziu um aumento da atividade antinociceptiva de uma baixa dose de crotalfina $(0,04 \mu \mathrm{g} / \mathrm{kg})$ somente na pata tratada com o inibidor. Assim, levando-se em conta a ausência de efeito do orlistat e o fato que o MAFP é um inibidor pouco seletivo de endocanabinóides, podendo interferir com a hidrólise de outros ácidos graxos, a participação de endocanabinóides no efeito da crotalfina continua incerto e ainda é avaliado por nosso grupo, em colaboração com o Grupo de Pesquisa sobre Endocannabinóides da Itália, utilizando ferramentas famacológicas mais seletivas e metodologias mais específicas.

Enquanto o envolvimento de endocanabinóides no efeito da crotalfina ainda é estudado, o entendimento sobre a interação do peptídeo analgésico sobre o sistema opióide se tornou prioridade. Uma vez que estudos preliminares que indicam que a crotalfina não é capaz de deslocar naloxona marcada $\left(\left[{ }^{3} \mathrm{H}\right]\right.$ naloxone) em estudos de "binding" (Correa, F., comunicação pessoal), este projeto buscou também avaliar a contribuição de peptídeos opióides endógenos para a antinocicepção induzida pela crotalfina, caracterizando assim uma atividade indireta no sistema opióide.

É importante ressaltar que Wittert e colaboradores (WITTERT et al., 1996) demonstraram que, além de serem encontrados no sistema nervoso (BODNAR; KLEIN, 2005), os três principais receptores para opióides ( $m u$, kappa e delta) também estão presentes no intestino, nas glândulas adrenais, rins, pulmões, baço, testículos, ovários, útero, estômago, fígado, endotélio vascular, epitélio cardíaco, células imunes e queratinócitos. Esta expressão de receptores opióides na periferia sugere que peptídeos opióides endógenos têm importante papel na regulação de processos fisiológicos. Além disso, a participação de opióides endógenos fora do sistema nervoso central no efeito da crotalfina não pode ser descartada porque desde a década de 1980 dados de literatura têm mostrado a presença desses opióides endógenos em tecidos periféricos, como neurônios aferentes primários, gânglios autonômicos, nervos entéricos e medula adrenal (NORTH; EGAN, 1983). No entanto, aproximadamente uma dúzia de peptídeos opióides endógenos é obtida após clivagem em diferentes pontos de três grandes moléculas protéicas: pró-opiomelanocortina, proencefalina e prodinorfina. Assim, nossos estudos se concentraram em avaliar a participação das mais importantes substâncias opióides geradas por estes precursores, sendo elas a $\beta$-endorfina, a met-encefalina 
e a dinorfina A (STEIN et al., 1990), utilizando inicialmente anticorpos contra cada um desses peptídeos endógenos.

Nossos dados demonstram que a administração intraplantar de anticorpos anti- $\beta$ endorfina e anti-met-encefalina não foram capazes de interferir no efeito da crotalfina. Por outro lado, o anticorpo anti-dinorfina A reverteu completamente a antinocicepção induzida pela crotalfina apenas na pata tratada, sem alterar o efeito antinociceptivo deste peptídeo na pata contralateral, sugerindo a participação deste peptídeo endógeno no efeito local da crotalfina.

Dados da literatura relatam que a degradação da dinorfina é quase completamente prevenida por uma mistura de três inibidores de peptidase: captopril, amastatin e fosforamidon. Ainda, ensaios comportamentais in vivo (BRUGOS; HOCHHAUS, 2004; KITAMURA et al., 2000), e in vitro (NUMATA et al., 1988), demonstram que a potencialização do efeito da dinorfina pode ser obtida também com preparações isoladas de cada inibidor. Assim, a fim de confirmar a participação de dinorfina A local no efeito do peptídeo analgésico, investigamos se a administração intraplantar de captopril é capaz de interferir no efeito da crotalfina. Os resultados demonstram que a administração intraplantar de $10 \mu \mathrm{g} /$ pata de captopril potencializou a atividade de uma baixa dose de crotalfina $(0,04$ $\mu \mathrm{g} / \mathrm{kg}$ ) somente na pata tratada com o inibidor, não interferindo com o limiar nociceptivo da pata contralateral e confirmando, portanto, a participação de dinorfina A local neste efeito.

Em relação à liberação de opióides endógenos e sua relação com o sistema canabinóide, Ibrahim e colaboradores (2005), avaliando a participação de $\beta$-endorfina no efeito antinociceptivo de agonistas $\mathrm{CB}_{2}$, demonstraram que a ativação de receptores $\mathrm{CB}_{2}$ produz antinocicepção indiretamente, pela liberação de $\beta$-endorfina contida em queratinócito presentes no tecido local. Diante destes relatos e dos nossos resultados que demonstram a participação de receptores periféricos kappa opióide, canabinóide do tipo $\mathrm{CB}_{2}$ e, ainda, do peptídeo opióide endógeno dinorfina A no efeito antinociceptivo da crotalfina, um ensaio imunoenzimático (ELISA) foi realizado para avaliar se a liberação de dinorfina A poderia ocorrer de tecidos periféricos locais, e se esta liberação seria dependente da ativação de receptores $\mathrm{CB}_{2}$. Para a realização deste ensaio, foram utilizados animais sensibilizados pela administração intraplantar de $\mathrm{PGE}_{2}$ para simular a hiperalgesia aguda utilizada como ferramenta experimental durante todo o desenvolvimento do projeto.

Os resultados comprovam que a crotalfina induz a liberação pelo tecido plantar somente de dinorfina A. Esta liberação, por sua vez, foi inibida pela pré-incubação do tecido 
plantar com antagonista $\mathrm{CB}_{2}$, sugerindo pela primeira vez que a liberação de dinorfina $\mathrm{A}$ induzida pela crotalfina é mediada por receptores $\mathrm{CB}_{2}$ em tecidos periféricos.

Receptores canabinóides, especialmente $\mathrm{CB}_{2}$, são amplamente expressos na periferia e em células imunes residentes ou infiltradas na pele, como por exemplo, linfócitos, mastócitos, monócitos, macrófagos e neutrófilos. Dados da literatura demonstraram que ambos tipos celulares - residentes e células migradas a partir de diferentes tecidos - podem libertar os opióides endógenos após diferentes tipos de estímulos (CABOT et al., 1997; CABOT et al., 2001; IBRAHIM et al., 2005). Além disso, Ibrahim et al. (2005) mostraram que os queratinócitos podem libertar $\beta$-endorfina após estimulação $\mathrm{CB}_{2}$. Os queratinócitos, entre outros componentes da pele tais como células residentes imunes e inflamatórias, podem libertar os péptidos opióides. As células imunes são a principal fonte de ligantes endógenos opióides na pele, devido à sua abundância em comparação com os queratinócitos residentes ou neurônios periféricos sensoriais (HASSAN et al., 1992; SCHAUER et al., 1994; STEIN, 1993). Tem sido demonstrado que peptídeos opióides estão contidos em leucócitos, linfócitos T e B, granulócitos e monócitos/macrófagos. Estes leucócitos contribuem para a inibição da dor endógena em diferentes fases de inflamação. Essas células contêm a sequência de mRNA para os precursores opióides endógenos e todo o arsenal enzimática necessária para o seu processamento para o péptido funcionalmente ativo (CABOT, 2001; HADLEY; HASKELLLUEVANO, 1999; HASSAN et al., 1992; SCHAUER et al., 1994; STEIN et al., 1990). É importante salientar que, até o momento, os tipos de células que liberam a dinorfina A, após estimulação por crotalfina não foi presentemente caracterizados.

Até o presente momento, nossos resultados demonstram que a crotalfina induz antinocicepção quando avaliada em modelo de hiperalgesia aguda induzida pela $\mathrm{PGE}_{2}$ e que este efeito envolve a participação do sistema canabinóide periférico, principalmente, receptor $\mathrm{CB}_{2}$. Ainda, nossos dados corroboram os dados anteriores do nosso grupo, uma vez que a crotalfina induziu um aumento na ativação de receptores kappa opióide no tecido plantar de ratos. Nossos resultados ainda indicam, pela primeira vez, que o efeito da crotalfina é dependente de liberação local de dinorfina A, agonista endógeno de receptores kappa, que produz antinocicepção por atuar nesse tipo de receptor opióide localizado em neurônios aferentes primários. Esta liberação é dependente de receptores $\mathrm{CB}_{2}$.

Apesar de demonstrarmos a interação existente entre os sistemas opioide e canabinoide no efeito antinociceptivo da crotalfina, os resultados até aqui obtidos ainda não nos permitiam sugerir se a crotalfina era capaz de acarretar ativação de receptores canabinóides do tipo 2 direta ou indiretamente, devido à liberação de endocanabinóides. Para 
tanto, foram realizados estudos de binding em receptores canabinóides no Instituto de Química Biomolecular do Conselho Nacional de Pesquisa (Consiglio Nazionale delle Ricerche, Pozzuoli, Itália) em colaboração com a Dra. Teresa Iuvone, da Universidade de Nápoles "Federico II" e Dr. Vincenzo Di Marzo, coordenador do Grupo de Pesquisa sobre Endocanabinóides localizado na Itália.

Neste tipo de ensaio de binding competitivo, uma única concentração de radioligante (usualmente um agonista) é usado em cada tubo de ensaio. O ligante clássico é utilizado em baixas concentrações, geralmente igual ou inferior ao valor do $\mathrm{K} d$, constante de dissociação, uma propriedade intrínseca de qualquer par de fármaco-receptor. Apesar de a $K d$ variar com a temperatura, a temperatura do corpo humano é relativamente constante, e, portanto, pode-se estabelecer que a $K d$ é uma constante para cada combinação de fármaco-receptor (RANG et al., 2007).

O nível de ligação específica do radioligante é então determinado na presença de uma gama de concentrações de outros concorrentes não-radioativos, a fim de medir a potência com a qual eles competem para a ligação do ligante radioativo. Nesta situação, o $\mathrm{IC}_{50}$ é a concentração de ligante de competição que desloca 50\% da ligação específica de radioligante. $\mathrm{O}$ valor de $\mathrm{IC}_{50}$ é convertido para uma inibição absoluta constante, $\mathrm{K} i$, utilizando a equação clássica de Cheng-Prusoff (CHENG; PRUSOFF, 1973).

Diversos ligantes canabinóides não são capazes de distinguir entre os receptores $\mathrm{CB}_{1} \mathrm{e}$ $\mathrm{CB}_{2}$, mesmo havendo somente cerca $44 \%$ de afinidade entre seqüências de aminoácidos para estes receptores. Este comportamento inespecífico pode ser explicado pela similaridade entre seus domínios de ligação ortostéricos (identidade de 68\%). De qualquer forma, já são descritos na Literatura diversos agonistas e antagonistas seletivos para cada subtipo de receptor, (DI MARZO et al., 2004).

Nossos estudos de ligação específica demonstram que a crotalfina se liga diretamente e eficazmente em receptores canabinóides do tipo $\mathrm{CB}_{2}$, e não do tipo $\mathrm{CB}_{1}$. Concentrações na ordem de nano molar do peptídeo foram capazes de deslocar o agonista radiomarcado ${ }^{[3 \mathrm{H}]} \mathrm{CP} 55,490$ em estudos de binding somente para receptores canabinóides do tipo $\mathrm{CB}_{2}$. Por outro lado, nem mesmo altas concentrações do peptídeo sintético demonstrou esta capacidade de deslocamento em estudos de binding para receptores do tipo $\mathrm{CB}_{1}$, destacando a alta afinidade da crotalfina por receptores $\mathrm{CB}_{2}$ dentro deste sistema.

Os valores experimentalmente obtidos de $\mathrm{IC}_{50}(2,5 \mathrm{nM})$ e $\mathrm{Ki}(0,54 \mathrm{nM})$ da crotalfina demonstram a alta afinidade deste peptídeo por receptores do tipo $\mathrm{CB}_{2}$, tornando-o um promissor fármaco em estudo. 
Apesar dos estudos recentes demonstrando eficácia da Cannabis sativa no tratamento da emese, glaucoma, anorexia, obesidade, esclerose múltipla, entre outros, seu uso continua limitado, devido a uma série de efeitos indesejáveis, relacionados às suas propriedades psicotrópicas mediadas por receptores do tipo $\mathrm{CB}_{1}$. Têm sido descrito, entre outros efeitos, a dificuldade de concentração, prejuízo da memória, euforia, confusão de pensamentos, sonolência, relaxamento, instabilidade no andar, alteração da memória imediata, diminuição da capacidade para a realização de tarefas que requeiram operações múltiplas e variadas, lentidão na capacidade de reação e déficit na aptidão motora (AMERI, 1999; ANAND et al., 2009; BONFA et al., 2008).

Nesse sentido, os estudos referentes às propriedades analgésicas dos canabinóides têm se concentrado preferencialmente, mas não exclusivamente, nos receptores $\mathrm{CB}_{2}$, uma vez que estes estão presentes principalmente na periferia e aparentemente não induzem efeitos psicotrópicos ou adversos severos (AMERI, 1999; ANAND et al., 2009; MARTIN; LICHTMAN, 1998).

É facilmente encontrado na literatura compostos como o WIN 55212-2, um competidor heterólogo para a ligação não especifica (Ki valores de 9,2 nM e 2,1 nM para os receptores $\mathrm{CB}_{1}$ e $\mathrm{CB}_{2}$, respectivamente). No entanto, atualmente, o JWH 133, desenvolvido por John William Huffman, é o agonista $\mathrm{CB}_{2}$ mais potente e seletivo para este receptor e, por isso, comumente utilizado na pesquisa científica. Este agente não só se liga facilmente em receptores $\mathrm{CB}_{2}$ (200 vezes mais do que receptores $\mathrm{CB}_{1}$; Ki 3,4 nM), mas também se comporta como um seletivo agonista $\mathrm{CB}_{2}$ em ensaios funcionais (HUFFMAN, 2005).

Todos estes dados em conjunto somados aos valores experimentalmente obtidos de $\mathrm{IC}_{50}(2,5 \mathrm{nM})$ e $\mathrm{Ki}(0,54 \mathrm{nM})$ da crotalfina demonstram afinidade e potência deste peptídeo por receptores do tipo $\mathrm{CB}_{2}$. Ainda, a crotalfina não demonstrou significante afinidade com os receptores $\mathrm{CB}_{1}$ em ensaios de binding, demonstrando alta seletividade entre os receptores canabinóides. Em suma, portanto, a crotalfina é provavelmente o primeiro peptídeo de origem animal com atividade farmacológica mediada por receptores canabinóides do tipo $\mathrm{CB}_{2}$ e, ainda, apresenta maior afinidade quando comparada a outros potentes fármacos canabinóides clássicos, tornando-o um promissor fármaco em estudo. 


\section{CONCLUSÃO}

Em suma, nossos resultados sugerem que a crotalfina é um potente agonista de receptores canabinóides do tipo 2, que induz antinocicepção em modelo de hiperalgesia aguda induzida pela prostaglandina $\mathrm{E}_{2}$ por atuação nestes receptores. Ainda, esta antinocicepção é decorrente da liberação local de dinorfina A, agonista endógeno de receptores kappa, que produz antinocicepção por atuar nesse tipo de receptor opióide localizado em neurônios aferentes primários. Esta liberação é dependente da ativação direta de receptores $\mathrm{CB}_{2}$. 


\section{REFERÊNCIAS ${ }^{*}$}

AIMONE, L. D.; YAKSH, T. L. Opioid modulation of capsaicin-evoked release of substance P from rat spinal cord in vivo. Peptides, v. 10, n. 6, p. 1127-1131, 1989.

AMARANTE, L. H.; DUARTE, I. D. The kappa-opioid agonist (+/-)-bremazocine elicits peripheral antinociception by activation of the L-arginine/nitric oxide/cyclic GMP pathway. Eur. J. Pharmacol., v. 454, n. 1, p. 19-23, 2002.

AMERI, A. The effects of cannabinoids on the brain. Prog. Neurobiol., v. 58, n. 4, p. $315-$ 348, 1999.

ANAND, P. et al. Targeting $\mathrm{CB}(2)$ receptors and the endocannabinoid system for the treatment of pain. Brain Res. Rev., v. 60, n. 1, p. 255-266, 2009.

ANTONIJEVIC, I. et al. Perineurial defect and peripheral opioid analgesia in inflammation. J Neurosc., v. 15, n. 1, pt 1, p. 165-172, 1995.

BAKER, D. et al. In silico patent searching reveals a new cannabinoid receptor. Trends Pharmacol. Sci., v. 27, n. 1, p. 1-4, 2006.

BARLOCCO, D. et al. The opioid-receptor-like 1 (ORL-1) as a potential target for new analgesics. Eur. J. Med. Chem., v. 35, n. 3, p. 275-282, 2000.

BELCHEVA, M. M. et al. Mu and kappa opioid receptors activate ERK/MAPK via different protein kinase $\mathrm{C}$ isoforms and secondary messengers in astrocytes. J. Biol. Chem., v. 280, n. 30, p. 27662-27669, 2005.

BELCHEVA, M. M. et al. Opioid modulation of extracellular signal-regulated protein kinase activity is ras-dependent and involves Gbetagamma subunits. J. Neurochem., v. 70, n. 2, p. 635-645, 1998.

BELMONTE, C.; CERVERO, E. Neurobioloy of receptors. Oxford: Oxford University Press, 1996.

BESSON, J. M. The neurobiology of pain. Lancet, v. 353, n. 9164, p. 1610-1615, 1999.

BEVAN, S. Nociceptive peripheral neurons: cellular properties. In: WALL, P. D.; MELZACK, R. (Ed.). Text book of pain. Edinburgh: Chuchill-Livingstone, 1999. p. 85-103

BISOGNO, T. et al. Biosynthesis, uptake, and degradation of anandamide and palmitoylethanolamide in leukocytes. J. Biol. Chem., v. 272, n. 6, p. 3315-3323, 1997.

BODNAR, R. J. Endogenous opiates and behavior: 2008. Peptides, v. 30, n. 12, p. 24322479, 2009.

\footnotetext{
* De acordo com: ASSOCIAÇÃO BRASILEIRA DE NORMAS TÉCNICAS. NBR 6023: informação e documentação: referências: elaboração. Rio de Janeiro, 2002.
} 
BODNAR, R. J.; KLEIN, G. E. Endogenous opiates and behavior: 2004. Peptides, v. 26, n. 12, p. 2629-2711, 2005.

BOHN, L. M. et al. Mitogenic signaling via endogenous kappa-opioid receptors in C6 glioma cells: evidence for the involvement of protein kinase $\mathrm{C}$ and the mitogen-activated protein kinase signaling cascade. J. Neurochem., v. 74, n. 2, p. 564-573, 2000.

BONFA, L. et al. Cannabinoids in chronic pain and palliative care. Rev. Bras. Anestesiol., v. 58, n. 3, p. 267-279, 2008.

BOUABOULA, M. et al. Stimulation of cannabinoid receptor CB1 induces krox-24 expression in human astrocytoma cells. J. Biol. Chem., v. 270, n. 23, p. 13973-13980, 1995.

BRIGATTE, P. et al. Tolerance to the antinociceptive effect of Crotalus durissus terrificus snake venom in mice is mediated by pharmacodynamic mechanisms. Toxicon, v. 39, n. 9, p. 1399-1410, 2001.

BRUCHAS, M. R. et al. Kappa opioid receptor activation of p38 MAPK is GRK3- and arrestin-dependent in neurons and astrocytes. J. Biol. Chem., v. 281, n. 26, p. 18081-18089, 2006.

BRUGOS, B.; HOCHHAUS, G. Metabolism of dynorphin A(1-13). Pharmazie, v. 59, n. 5, p. 339-343, 2004.

BURGOS, E. et al. Antinociceptive effect of the cannabinoid agonist, WIN 55,212-2, in the orofacial and temporomandibular formalin tests. Eur. J. Pain., 2009.

BUSHLIN, I. et al. Cannabinoid-opioid interactions during neuropathic pain and analgesia. Curr Opin. Pharmacol., 2009.

CABOT, P. J. Immune-derived opioids and peripheral antinociception. Clin. Exp. Pharmacol. Physiol., v. 28, n. 3, p. 230-232, 2001.

CABOT, P. J. et al. Immune cell-derived beta-endorphin. Production, release, and control of inflammatory pain in rats. J. Clin. Invest., v. 100, n. 1, p. 142-148, 1997.

CABOT, P. J. et al. Methionine-enkephalin-and Dynorphin A-release from immune cells and control of inflammatory pain. Pain, v. 93, n. 3, p. 207-212, 2001.

CABRAL, G. A. et al. Cannabinoid-mediated inhibition of inducible nitric oxide production by rat microglial cells: evidence for CB1 receptor participation. Adv. Exp. Med. Biol., v. 493, p. 207-214, 2001.

CAVIEDES, B. E.; HERRANZ, J. L. [Advances in physiopathology and the treatment of neuropathic pain]. Rev. Neurol., v. 35, n. 11, p. 1037-1048, 2002.

CELERIER, E. et al. Long-lasting hyperalgesia induced by fentanyl in rats: preventive effect of ketamine. Anesthesiology, v. 92, n. 2, p. 465-472, 2000. 
CHACUR, M. et al. Hyperalgesia induced by Asp49 and Lys49 phospholipases A(2) from Bothrops asper snake venom: pharmacological mediation and molecular determinants. Toxicon, v. 41, n. 6, p. 667-678, 2003.

CHENG, Y.; PRUSOFF, W. H. Relationship between the inhibition constant (K1) and the concentration of inhibitor which causes 50 per cent inhibition (I50) of an enzymatic reaction. Biochem. Pharmacol., v. 22, n. 23, p. 3099-3108, 1973.

CHIANESE, G. et al. Desulfohaplosamate, a new phosphate-containing steroid from Dasychalina sp., is a selective cannabinoid CB2 receptor ligand. Steroids, v. 76, n. 10-11, p. 998-1002, 2011.

CICHEWICZ, D. L. Synergistic interactions between cannabinoid and opioid analgesics. Life Sci., v. 74, n. 11, p. 1317-1324, 2004.

COMPTON, P. et al. Withdrawal hyperalgesia after acute opioid physical dependence in nonaddicted humans: a preliminary study. J. Pain, v. 4, n. 9, p. 511-519, 2003.

COX, M. L. et al. The antinociceptive effect of Delta9-tetrahydrocannabinol in the arthritic rat involves the $\mathrm{CB}(2)$ cannabinoid receptor. Eur. J. Pharmacol., v. 570, n. 1-3, p. 50-56, 2007.

CUNHA, F. Q. et al. Pharmacological modulation of secondary mediator systems--cyclic AMP and cyclic GMP--on inflammatory hyperalgesia. Br. J. Pharmacol., v. 127, n. 3, p. 671-678, 1999.

CUNHA, T. M. et al. Morphine peripheral analgesia depends on activation of the PI3Kgamma/AKT/nNOS/NO/KATP signaling pathway. Proc. Natl. Acad. Sci. U. S. A., v. 107, n. 9, p. 4442-4447, 2010.

CURY, Y.; PICOLO, G. Animal toxins as analgesics--an overview. Drug News Perspect, v. 19, n. 7, p. 381-392, 2006.

DA FONSECA PACHECO, D. et al. The mu-opioid receptor agonist morphine, but not agonists at delta- or kappa-opioid receptors, induces peripheral antinociception mediated by cannabinoid receptors. Br. J. Pharmacol., v. 154, n. 5, p. 1143-1149, 2008.

DAI, Y. et al. Phosphorylation of extracellular signal-regulated kinase in primary afferent neurons by noxious stimuli and its involvement in peripheral sensitization. J. Neurosc., v. 22, n. 17, p. 7737-7745, 2002.

DESROCHES, J.; BEAULIEU, P. Opioids and cannabinoids interactions: involvement in pain management. Curr. Drug Targets, v. 11, n. 4, p. 462-473, 2011.

DI MARZO, V. et al. The endocannabinoid system and its therapeutic exploitation. Nat. Rev. Drug Discov., v. 3, n. 9, p. 771-784, 2004.

DI MARZO, V. et al. Biosynthesis and inactivation of the endocannabinoid 2arachidonoylglycerol in circulating and tumoral macrophages. Eur. J. Biochem., v. 264, n. 1, p. 258-267, 1999. 
DI MARZO, V. et al. Formation and inactivation of endogenous cannabinoid anandamide in central neurons. Nature, v. 372, n. 6507, p. 686-691, 1994.

DICKENSON, A. H.; SULLIVAN, A. F. Evidence for a role of the NMDA receptor in the frequency dependent potentiation of deep rat dorsal horn nociceptive neurones following $\mathrm{C}$ fibre stimulation. Neuropharmacology, v. 26, n. 8, p. 1235-1238, 1987.

DINA, O. A. et al. Role of the sensory neuron cytoskeleton in second messenger signaling for inflammatory pain. Neuron, v. 39, n. 4, p. 613-624, 2003.

DRAY, A. Inflammatory mediators of pain. Br. J. Anaesth., v. 75, n., p. 125-131, 1995.

ENGLAND, S. et al. PGE2 modulates the tetrodotoxin-resistant sodium current in neonatal rat dorsal root ganglion neurones via the cyclic AMP-protein kinase A cascade. J. Physiol., v. 495 ( Pt 2), n., p. 429-440, 1996.

FELDER, C. C. et al. Comparison of the pharmacology and signal transduction of the human cannabinoid CB1 and CB2 receptors. Mol. Pharmacol., v. 48, n. 3, p. 443-450, 1995.

FERNANDEZ-RUIZ, J. et al. Cannabinoid CB2 receptor: a new target for controlling neural cell survival? Trends Pharmacol. Sci., v. 28, n. 1, p. 39-45, 2007.

FERREIRA, S. H. Prostaglandins, aspitin-like drugs and analgesia. Nature New Biol., v. 240, n., p. 200-203, 1972.

FERREIRA, S. H. Inflammation, prostaglandins and aspirin-like drugs. Trans. Med. Soc. Lond., v. 89, n., p. 20-31, 1973.

FERREIRA, S. H.; LORENZETTI, B. B. Prostaglandin hyperalgesia, IV: a metabolic process. Prostaglandins, v. 21, n. 5, p. 789-792, 1981.

FERREIRA, S. H.; LORENZETTI, B. B. Glutamate spinal retrograde sensitization of primary sensory neurons associated with nociception. Neuropharmacology, v. 33, n. 11, p. 14791485, 1994.

FERREIRA, S. H.; LORENZETTI, B. B. Glutamate spinal retrograde sensitization of primary sensory neurons associated with nociception. Neuropharmacology, v. 33, n., p. 1479, 1995.

FERREIRA, S. H. et al. Is methylnalorphinium the prototype of an ideal peripheral analgesic? Eur. J. Pharmacol., v. 99, n. 1, p. 23-29, 1984.

FERREIRA, S. H.; NAKAMURA, M. I - Prostaglandin hyperalgesia, a cAMP/Ca2+ dependent process. Prostaglandins, v. 18, n. 2, p. 179-190, 1979 a.

FERREIRA, S. H.; NAKAMURA, M. II - Prostaglandin hyperalgesia: the peripheral analgesic activity of morphine, enkephalins and opioid antagonists. Prostaglandins, v. 18, n. 2, p. 191-200, 1979 b. 
FERREIRA, S. H.; NAKAMURA, M. III - Prostaglandin hyperalgesia: relevance of the peripheral effect for the analgesic action of opioid-antagonists. Prostaglandins, v. 18, n. 2 , p. 201-208, 1979 c.

FOLEY, K. M.; INTURRISI, C. E. Analgesic drug therapy in cancer pain: principles and practice. Med. Clin. North. Am., v. 71, n. 2, p. 207-232, 1987.

GALIEGUE, S. et al. Expression of central and peripheral cannabinoid receptors in human immune tissues and leukocyte subpopulations. Eur. J. Biochem., v. 232, n. 1, p. 54-61, 1995.

GARZON, J. et al. Influence of $\mathrm{Gz}$ and $\mathrm{Gi} 2$ transducer proteins in the affinity of opioid agonists to mu receptors. Eur. J. Neurosci., v. 10, n. 8, p. 2557-2564, 1998.

GATLEY, S. J. et al. Binding of the non-classical cannabinoid CP 55,940, and the diarylpyrazole AM251 to rodent brain cannabinoid receptors. Life Sci., v. 61, n. 14, p. PL 191-197, 1997.

GEBREMEDHIN, D. et al. Cannabinoid CB1 receptor of cat cerebral arterial muscle functions to inhibit L-type Ca2+ channel current. Am. J. Physiol., v. 276, n. 6 Pt 2, p. H2085-2093, 1999.

GIORGI, R. Antinociceptive activity of Crotalus durissus terrificus snake venom. Journal of venom of animal toxins, v. 3, n. 1, p. 104, 1996.

GIORGI, R. et al. Analgesic effect evoked by low molecular weight substances extracted from Crotalus durissus terrificus venom. Toxicon, v. 31, n. 10, p. 1257-1265, 1993.

GOUTOPOULOS, A.; MAKRIYANNIS, A. From cannabis to cannabinergics: new therapeutic opportunities. Pharmacol. Ther., v. 95, n. 2, p. 103-117, 2002.

GRANADOS-SOTO, V. et al. Evidence for the involvement of the nitric oxide-cGMP pathway in the antinociception of morphine in the formalin test. Eur. J. Pharmacol., v. 340, n. 2-3, p. 177-180, 1997.

GUERRERO, A. V. et al. Peripheral cannabinoids attenuate carcinoma-induced nociception in mice. Neurosc. Lett., v. 433, n. 2, p. 77-81, 2008.

GUIGNARD, B. et al. Acute opioid tolerance: intraoperative remifentanil increases postoperative pain and morphine requirement. Anesthesiology, v. 93, n. 2, p. 409-417, 2000.

GUPTA, A. et al. Conformation state-sensitive antibodies to G-protein-coupled receptors. J. Biol. Chem., v. 282, n. 8, p. 5116-5124, 2007.

GUTIERREZ, T. et al. Activation of peripheral cannabinoid CB1 and CB2 receptors suppresses the maintenance of inflammatory nociception: a comparative analysis. Br. J. Pharmacol., v. 150, n. 2, p. 153-163, 2007. 
GUTIERREZ, V. P. et al. Crotalphine induces potent antinociception in neuropathic pain by acting at peripheral opioid receptors. Eur. J. Pharmacol., v. 594, n. 1-3, p. 84-92, 2008.

GUTIERREZ, V. P. et al. The peripheral L-arginine-nitric oxide-cyclic GMP pathway and ATP-sensitive $\mathrm{K}+$ channels are involved in the antinociceptive effect of crotalphine on neuropathic pain in rats. Behav. Pharmacol., 2012.

HADLEY, M. E.; HASKELL-LUEVANO, C. The proopiomelanocortin system. Ann. N. Y. Acad. Sci., v. 885, n., p. 1-21, 1999.

HAJOS, N. et al. Cell type- and synapse-specific variability in synaptic GABAA receptor occupancy. Eur. J. Neurosc., v. 12, n. 3, p. 810-818, 2000.

HASSAN, A. H. et al. Dynorphin, a preferential ligand for kappa-opioid receptors, is present in nerve fibers and immune cells within inflamed tissue of the rat. Neurosc. Lett., v. 140, n. 1, p. 85-88, 1992.

HERKENHAM, M. et al. Cannabinoid receptor localization in brain. Proc. Natl. Acad. Sci. U. S. A., v. 87, n. 5, p. 1932-1936, 1990.

HILLARD, C. J. et al. Synthesis and characterization of potent and selective agonists of the neuronal cannabinoid receptor (CB1). J. Pharmacol. Exp. Ther., v. 289, n. 3, p. 14271433, 1999.

HOSOHATA, Y. et al. AM630 antagonism of cannabinoid-stimulated [35S]GTP gamma S binding in the mouse brain. Eur. J. Pharmacol., v. 321, n. 1, p. R1-3, 1997.

HOWLETT, A. C. et al. Cannabinoid physiology and pharmacology: 30 years of progress. Neuropharmacology, v. 47 Suppl 1, n., p. 345-358, 2004.

HUFFMAN, J. W. CB2 receptor ligands. Mini Rev. Med. Chem., v. 5, n. 7, p. 641-649, 2005.

IBRAHIM, M. M. et al. Activation of CB2 cannabinoid receptors by AM1241 inhibits experimental neuropathic pain: pain inhibition by receptors not present in the CNS. Proc. Natl. Acad. Sci. U. S. A., v. 100, n. 18, p. 10529-10533, 2003.

IBRAHIM, M. M. et al. CB2 cannabinoid receptor activation produces antinociception by stimulating peripheral release of endogenous opioids. Proc. Natl. Acad. Sci. U. S. A., v. 102, n. 8, p. 3093-3098, 2005.

JAYAMANNE, A. et al. Actions of the FAAH inhibitor URB597 in neuropathic and inflammatory chronic pain models. Br. J. Pharmacol., v. 147, n. 3, p. 281-288, 2006.

JENSEN, K. B. et al. Increased sensitivity to thermal pain following a single opiate dose is influenced by the COMT val(158)met polymorphism. PLoS One, v. 4, n. 6, p. e6016, 2009. 
JI, R. R.; WOOLF, C. J. Neuronal plasticity and signal transduction in nociceptive neurons: implications for the initiation and maintenance of pathological pain. Neurobiol. Dis., v. 8, n. 1, p. 1-10, 2001.

JULIUS, D.; BASBAUM, A. I. Molecular mechanisms of nociception. Nature, v. 413, n. 6852, p. 203-210, 2001.

KATONA, I. et al. GABAergic interneurons are the targets of cannabinoid actions in the human hippocampus. Neuroscience, v. 100, n. 4, p. 797-804, 2000.

KIDD, B. L.; URBAN, L. A. Mechanisms of inflammatory pain. Br. J. Anaesth., v. 87, n. 1, p. 3-11, 2001.

KITAMURA, K. et al. Effects of peptidase inhibitors on anti-nociceptive action of dynorphin(1-8) in rats. Naunyn Schmiedebergs Arch. Pharmacol., v. 361, n. 3, p. 273-278. 2000.

KONNO, K. et al. Crotalphine, a novel potent analgesic peptide from the venom of the South American rattlesnake Crotalus durissus terrificus. Peptides, v. 29, n. 8, p. 1293-1304, 2008.

LAN, R. et al. Structure-activity relationships of pyrazole derivatives as cannabinoid receptor antagonists. J. Med. Chem., v. 42, n. 4, p. 769-776, 1999.

LIGRESTI, A. et al. Kavalactones and the endocannabinoid system: the plant-derived yangonin is a novel CB(1) receptor ligand. Pharmacol. Res., v. 66, n. 2, p. 163-169, 2012.

LOHSE, M. J. et al. beta-Arrestin: a protein that regulates beta-adrenergic receptor function. Science, v. 248, n. 4962, p. 1547-1550, 1990.

LORENZETTI, B. B.; FERREIRA, S. H. The analgesic effect of quaternary analogues of morphine and nalorphine. Braz. J. Med. Biol. Res., v. 15, n. 4-5, p. 285-290, 1982.

LORENZETTI, B. B.; FERREIRA, S. H. Activation of the arginine-nitric oxide pathway in primary sensory neurons contributes to dipyrone-induced spinal and peripheral analgesia. Inflamm. Res., v. 45, n. 6, p. 308-311, 1996.

LYNN, A. B.; HERKENHAM, M. Localization of cannabinoid receptors and nonsaturable high-density cannabinoid binding sites in peripheral tissues of the rat: implications for receptor-mediated immune modulation by cannabinoids. J. Pharmacol. Exp. Ther., v. 268, n. 3, p. 1612-1623, 1994.

MALAN, T. P., JR. et al. CB2 cannabinoid receptor-mediated peripheral antinociception. Pain, v. 93, n. 3, p. 239-245, 2001.

MARTIN, B. R.; LICHTMAN, A. H. Cannabinoid transmission and pain perception. Neurobiol. Dis., v. 5, n. 6 Pt B, p. 447-461, 1998.

MECHOUlam, R. et al. Endocannabinoids. Eur. J. Pharmacol., v. 359, n. 1, p. 1-18, 1998.

MILLAN, M. J. Multiple opioid systems and pain. Pain, v. 27, n. 3, p. 303-347, 1986. 
MILLAN, M. J. The induction of pain: an integrative review. Prog. Neurobiol., v. 57, n. 1, p. 1-164, 1999.

NORTH, R. A.; EGAN, T. M. Actions and distributions of opioid peptides in peripheral tissues. Br. Med. Bull, v. 39, n. 1, p. 71-75, 1983.

NUMATA, $\mathrm{H}$. et al. Inactivation of dynorphin-(1-8) in isolated preparations by three peptidases. Jpn J. Pharmacol., v. 47, n. 4, p. 417-423, 1988.

O'SULLIVAN, S. E. Cannabinoids go nuclear: evidence for activation of peroxisome proliferator-activated receptors. Br. J. Pharmacol., v. 152, n. 5, p. 576-582, 2007.

OBARA, I. et al. Local peripheral opioid effects and expression of opioid genes in the spinal cord and dorsal root ganglia in neuropathic and inflammatory pain. Pain, v. 141, n. 3, p. 283-291, 2009.

PAROLARO, D. et al. Cellular mechanisms underlying the interaction between cannabinoid and opioid system. Curr. Drug Targets, v. 11, n. 4, p. 393-405, 2011.

PATEL, N. A. et al. Arachidonylethanolamide (AEA) activation of FOS proto-oncogene protein immunoreactivity in the rat brain. Brain Res., v. 797, n. 2, p. 225-233, 1998.

PERTWEE, R. G. Cannabinoid receptors and pain. Prog. Neurobiol., v. 63, n. 5, p. 569$611,2001$.

PERTWEE, R. G. Receptors and channels targeted by synthetic cannabinoid receptor agonists and antagonists. Curr. Med. Chem., v. 17, n. 14, p. 1360-1381, 2010.

PESTONJAMASP, V. K.; BURSTEIN, S. H. Anandamide synthesis is induced by arachidonate mobilizing agonists in cells of the immune system. Biochim. Biophys. Acta, v. 1394, n. 2-3, p. 249-260, 1998.

PICOLO, G. et al. Activation of peripheral ATP-sensitive $\mathrm{K}+$ channels mediates the antinociceptive effect of Crotalus durissus terrificus snake venom. Eur. J. Pharmacol., v. 469, n. 1-3, p. 57-64, 2003.

PICOLO, G.; CURY, Y. Peripheral neuronal nitric oxide synthase activity mediates the antinociceptive effect of Crotalus durissus terrificus snake venom, a delta- and kappa-opioid receptor agonist. Life Sci., v. 75, n. 5, p. 559-573, 2004.

PICOLO, G. et al. The antinociceptive effect of Crotalus durissus terrificus snake venom is mainly due to a supraspinally integrated response. Toxicon, v. 36, n. 1, p. 223-227, 1998.

PICOLO, G. et al. delta-opioid receptors and nitric oxide mediate the analgesic effect of Crotalus durissus terrificus snake venom. Eur. J. Pharmacol., v. 391, n. 1-2, p. 55-62, 2000 .

PINI, A. et al. The Role of Cannabinoids In Inflammatory Modulation of Allergic Respiratory Disorders, Inflammatory Pain and Ischemic Stroke. Curr. Drug. Targets., 2012. 
PIOMELLI, D. The molecular logic of endocannabinoid signalling. Nat. Rev. Neurosci., v. 4, n. 11, p. 873-884, 2003.

PRZEWLOCKI, R.; PRZEWLOCKA, B. Opioids in chronic pain. Eur. J. Pharmacol., v. 429, n. 1-3, p. 79-91, 2001.

RACHINGER-ADAM, B. et al. Pharmacology of peripheral opioid receptors. Curr Opin Anaesthesiol., v. 24, n. 4, p. 408-413, 2011.

RANDALL, L. O.; SELITTO, J. J. A method for measurement of analgesia activity on inflamed tissue. Arch. Inst. Pharmacodyn., v. 111, p. 209-219, 1957.

RANG, H. P. et al. Farmacologia. Rio de Janeiro: Guanabara Koogan. 2007.

REICHLING, D. B.; LEVINE, J. D. The primary afferent nociceptor as pattern generator. Pain, v. Suppl 6, n., p. S103-109, 1999.

REISINE, T. et al. Molecular mechanisms of opiate receptor coupling to $\mathrm{G}$ proteins and effector systems. Ann. N. Y. Acad. Sci., v. 780, n., p. 168-175, 1996.

RODRIGUEZ, J. J. et al. Ultrastructural localization of the CB1 cannabinoid receptor in muopioid receptor patches of the rat Caudate putamen nucleus. J. Neurosci., v. 21, n. 3, p. 823-833, 2001.

ROSS, R. A. et al. Agonist-inverse agonist characterization at CB1 and CB2 cannabinoid receptors of L759633, L759656, and AM630. Br. J. Pharmacol., v. 126, n. 3, p. 665-672, 1999.

RUEDA, D. et al. The CB(1) cannabinoid receptor is coupled to the activation of c-Jun Nterminal kinase. Mol. Pharmacol., v. 58, n. 4, p. 814-820, 2000.

SACHS, D. et al. Peripheral analgesic blockade of hypernociception: activation of arginine/NO/cGMP/protein kinase G/ATP-sensitive K+ channel pathway. Proc. Natl. Acad. Sci. U S A, v. 101, n. 10, p. 3680-3685, 2004.

SAEGUSA, H. et al. Effects of ablation of $\mathrm{N}$ - and R-type $\mathrm{Ca}(2+)$ channels on pain transmission. Neurosc. Res., v. 43, n. 1, p. 1-7, 2002.

SAGAR, D. R. et al. Inhibitory effects of CB1 and CB2 receptor agonists on responses of DRG neurons and dorsal horn neurons in neuropathic rats. Eur. J. Neurosc., v. 22, n. 2, p. 371-379, 2005.

SCHAIBLE, H. G.; RICHTER, F. Pathophysiology of pain. Langenbecks Arch. Surg., v. 389, n. 4, p. 237-243, 2004.

SCHAUER, E. et al. Proopiomelanocortin-derived peptides are synthesized and released by human keratinocytes. J. Clin. Invest., v. 93, n. 5, p. 2258-2262, 1994. 
SCHUlTZ, J.; GROSS, G. Opioids and cardioprotection. Pharmac. Ther., v. 89, n., p. 123-137, 2001.

SMITH, P. B. et al. Interactions between delta 9-tetrahydrocannabinol and kappa opioids in mice. J. Pharmacol. Exp. Ther., v. 268, n. 3, p. 1381-1387, 1994.

STEIN, C. Peripheral mechanisms of opioid analgesia. Anesth. Analg., v. 76, n. 1, p. 182191, 1993.

STEIN, C. et al. Local opioid receptors mediating antinociception in inflammation: endogenous ligands. Prog. Clin. Biol. Res., v. 328, n., p. 425-427, 1990.

STEIN, C.; LANG, L. J. Peripheral mechanisms of opioid analgesia. Curr. Opin. Pharmacol., v. 9, n. 1, p. 3-8, 2009.

STEIN, C. et al. Peripheral opioid receptors mediating antinociception in inflammation. Evidence for involvement of mu, delta and kappa receptors. J. Pharmacol. Exp. Ther., v. 248, n. 3, p. 1269-1275, 1989.

STEIN, C.; ZOLLNER, C. Opioids and sensory nerves. Handb. Exp. Pharmacol., v., n. 194, p. 495-518, 2009.

TAIWO, Y. O.; LEVINE, J. D. Kappa- and delta-opioids block sympathetically dependent hyperalgesia. J. Neurosc., v. 11, n. 4, p. 928-932, 1991.

TRIGO, J. M. et al. The endogenous opioid system: A common substrate in drug addiction. Drug Alcohol Depend., 2009.

VADIVELU, N. et al. Peripheral opioid receptor agonists for analgesia: a comprehensive review. J. Opioid Manag., v. 7, n. 1, p. 55-68, 2011.

VAN SICKLE, M. D. et al. Identification and functional characterization of brainstem cannabinoid CB2 receptors. Science, v. 310, n. 5746, p. 329-332, 2005.

VANDERAH, T. W. Pathophysiology of pain. Med. Clin. North. Am., v. 91, n. 1, p. 1-12, 2007.

VANEGAS, H.; SCHAIBLE, H. Effects of antagonists to high-threshold calcium channels upon spinal mechanisms of pain, hyperalgesia and allodynia. Pain, v. 85, n. 1-2, p. 9-18, 2000.

WALKER, J. M.; HUANG, S. M. Endocannabinoids in pain modulation. Prostaglandins Leukot Essent Fatty Acids, v. 66, n. 2-3, p. 235-242, 2002.

WALKER, J. S. Anti-inflammatory effects of opioids. Adv. Exp. Med. Biol., v. 521, n., p. 148-160, 2003.

WALLACE, M. et al. Dose-dependent effects of smoked cannabis on capsaicin-induced pain and hyperalgesia in healthy volunteers. Anesthesiology, v. 107, n. 5, p. 785-796, 2007. 
WELCH, S. P. Interaction of the cannabinoid and opioid systems in the modulation of nociception. Int. Rev. Psychiatry, v. 21, n. 2, p. 143-151, 2009.

WELCH, S. P.; EADS, M. Synergistic interactions of endogenous opioids and cannabinoid systems. Brain Res., v. 848, n. 1-2, p. 183-190, 1999.

WILLIAMS, J. A. et al. A circadian output in Drosophila mediated by neurofibromatosis-1 and Ras/MAPK. Science, v. 293, n. 5538, p. 2251-2256, 2001.

WITTERT, G. et al. Tissue distribution of opioid receptor gene expression in the rat. Biochem Biophys. Res. Commun., v. 218, n. 3, p. 877-881, 1996.

WOOLF, C. J. Pain. Neurobiol. Dis., v. 7, n. 5, p. 504-510, 2000.

WOOLF, C. J. Pain: moving from symptom control toward mechanism-specific pharmacologic management. Ann. Intern. Med., v. 140, n. 6, p. 441-451, 2004.

YAKSH, T. L. Spinal systems and pain processing: development of novel analgesic drugs with mechanistically defined models. Trends Pharmacol. Sci., v. 20, n. 8, p. 329-337, 1999.

ZHANG, Y. et al. Intrathecal morphine reduces allodynia after peripheral nerve injury in rats via activation of a spinal A1 adenosine receptor. Anesthesiology, v. 102, n. 2, p. 416-420, 2005.

ZUARDI, A. W. History of cannabis as a medicine: a review. Rev. Bras. Psiquiatr., v. 28, n. 2, p. 153-157, 2006. 